Report of Investigations 2015-2

\title{
THE 2008 PHREATOMAGMATIC ERUPTION OF OKMOK VOLCANO, ALEUTIAN ISLANDS, ALASKA: CHRONOLOGY, DEPOSITS, AND LANDFORM CHANGES
}

by

J.F. Larsen, C.A. Neal, J.R. Schaefer, A.M. Kaufman, and Z. Lu

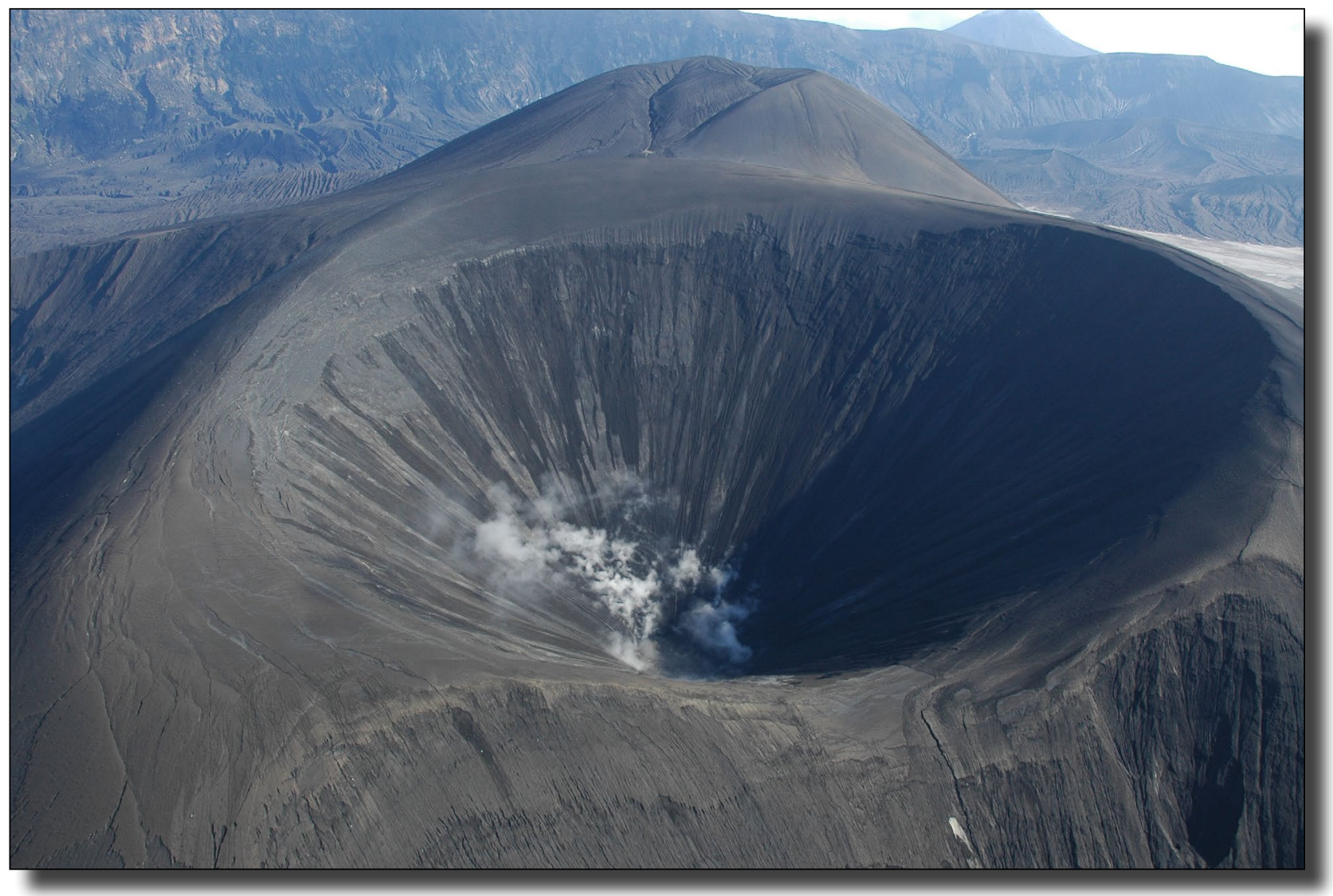

A view of the new Ahmanilix tephra cone with steam rising from a diffuse area on the crater floor. Ahmanilix is a $300-m$-tall cone marking the primary 2008 vent. View is looking to the east, with Cone D directly behind Ahmanilix and mantled by a thick layer of tephra. Photograph by C. Neal (USGS), September 15, 2008.

\section{Published by}

STATE OF ALASKA

DEPARTMENT OF NATURAL RESOURCES

DIVISION OF GEOLOGICAL \& GEOPHYSICAL SURVEYS 

Report of Investigations 2015-2

\section{THE 2008 PHREATOMAGMATIC ERUPTION OF OKMOK VOLCANO, ALEUTIAN ISLANDS, ALASKA: CHRONOLOGY, DEPOSITS, AND LANDFORM CHANGES \\ by \\ J.F. Larsen, C.A. Neal, J.R. Schaefer, A.M. Kaufman, and Z. Lu}

2015

This DGGS Report of Investigations is a final report of scientific research. It has received technical review and may be cited as an agency publication. 


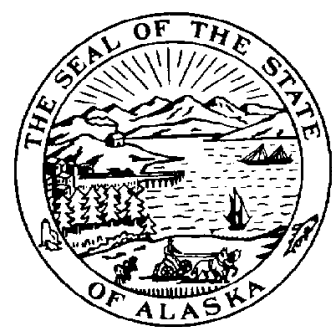

STATE OF ALASKA

Bill Walker, Governor

DEPARTMENT OF NATURAL RESOURCES

Mark D. Myers, Ph.D., Commissioner

\section{DIVISION OF GEOLOGICAL \& GEOPHYSICAL SURVEYS Steve Masterman, Director and State Geologist}

Publications produced by the Division of Geological \& Geophysical Surveys (DGGS) are available for free download from the DGGS website (www.dggs.alaska.gov). Publications on hard-copy or digital media can be examined or purchased in the Fairbanks office:

\section{Alaska Division of Geological \& Geophysical Surveys 3354 College Rd., Fairbanks, Alaska 99709-3707 \\ Phone: (907) 451-5020 Fax (907) 451-5050 \\ dggspubs@alaska.gov \\ www.dggs.alaska.gov}

\author{
Alaska State Library \\ State Office Building, 8th Floor \\ 333 Willoughby Avenue \\ Juneau, Alaska 99811-0571 \\ Elmer E. Rasmuson Library \\ University of Alaska Fairbanks \\ Fairbanks, Alaska 99775-1005
}

\author{
Alaska Resource Library \& Information \\ Services (ARLIS) \\ 3150 C Street, Suite 100 \\ Anchorage, Alaska 99503-3982 \\ University of Alaska Anchorage Library \\ 3211 Providence Drive \\ Anchorage, Alaska 99508-4614
}

This publication released by the Division of Geological \& Geophysical Surveys was produced and printed in Fairbanks, Alaska, at a cost of \$5.00. Publication is authorized by Alaska Statute 41, which charges the division "to determine the potential of Alaskan land for production of metals, minerals, fuels, and geothermal resources; the location and supplies of groundwater and construction materials; the potential geologic hazards to buildings, roads, bridges, and other installations and structures; and shall conduct such other surveys and investigations as will advance knowledge of the geology of Alaska." 


\section{CONTENTS}

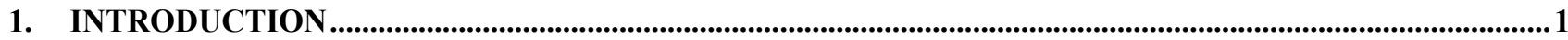

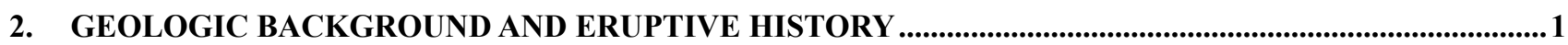

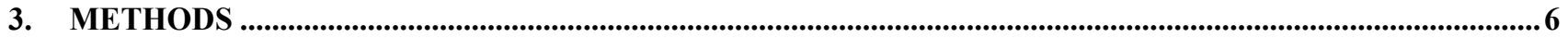

3.1 Geologic observations, sampling, and eruption volume estimates .................................................................

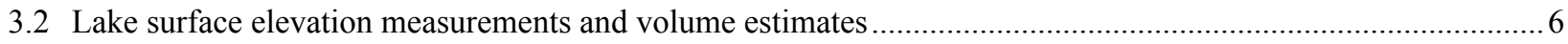

3.3 Synthetic Aperture Radar (SAR) analysis ...............................................................................................

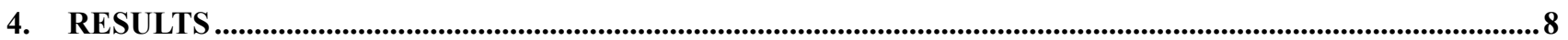

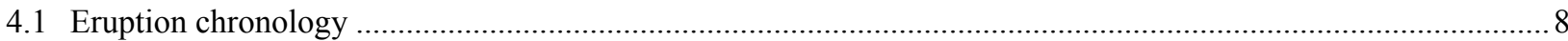

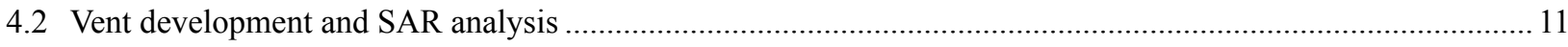

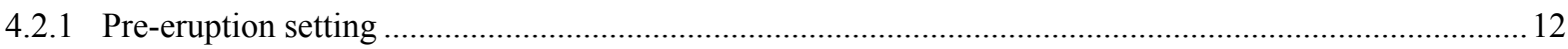

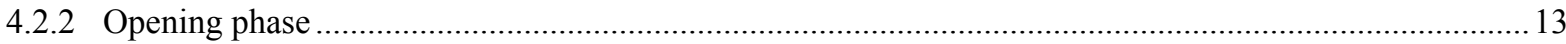

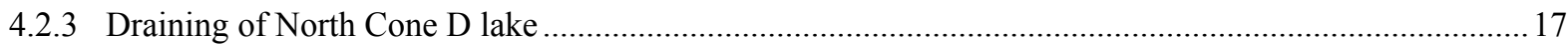

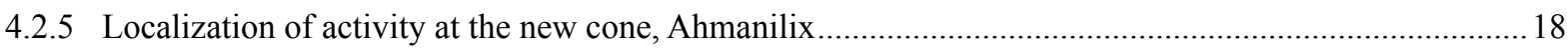

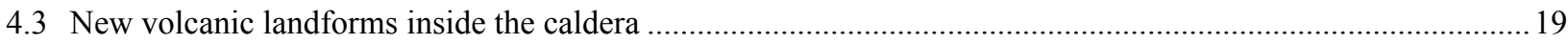

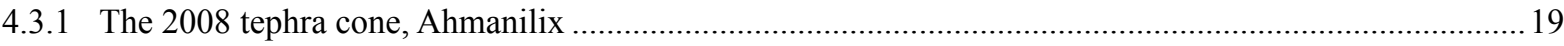

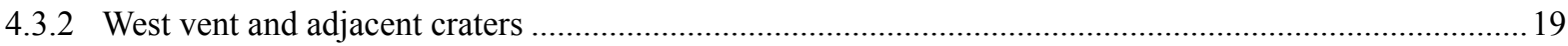

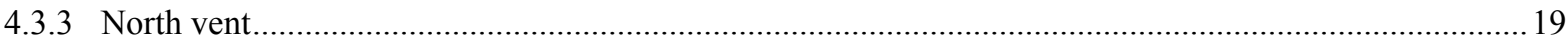

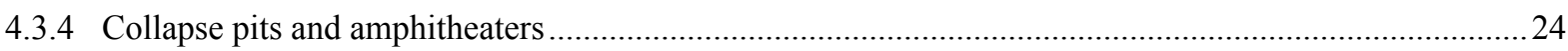

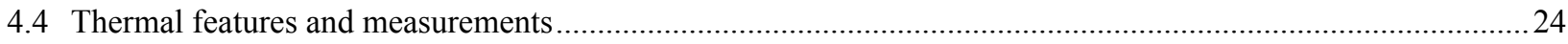

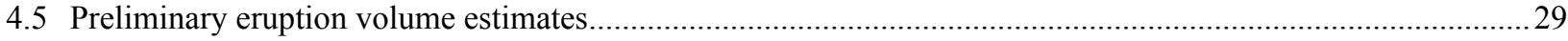

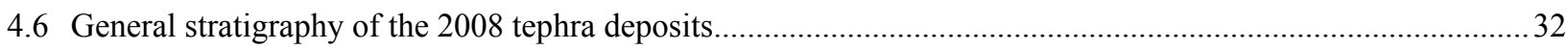

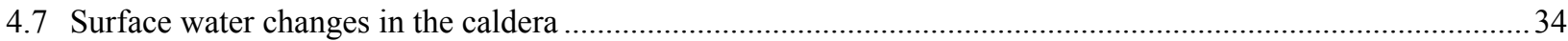

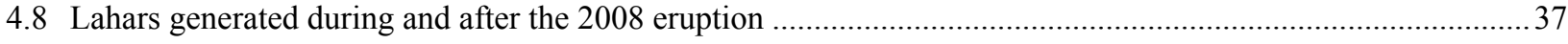

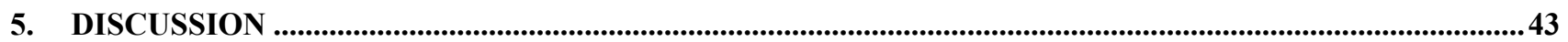

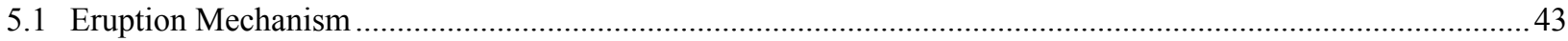

5.1.1 Size and explosivity in comparison with recent Okmok eruptions .......................................................... 43

5.1.2 Eruptive volume comparison: 2008 versus 1997, 1958, and 1945 eruptions............................................. 44

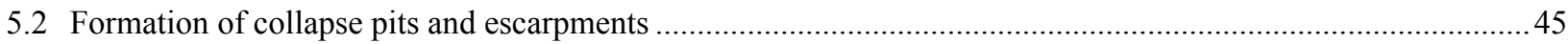

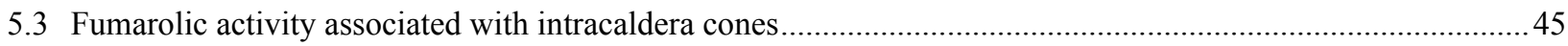

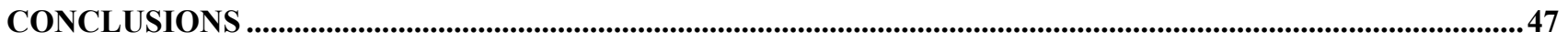

ACKNOWLEDGMENTS ..........................................................................................................................4

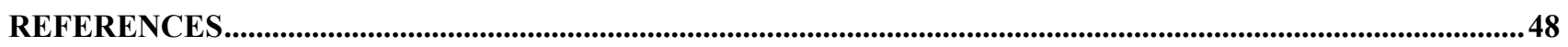

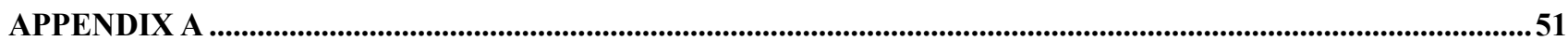




\section{FIGURES}

Figure 1. Location of Okmok volcano in the central Aleutian Islands with respect to nearby volcanoes and communities

2. Geologic map of Okmok volcano modified from Byers (1959), showing selected map units in the caldera (cones A, B, and D) and major Holocene and Pleistocene map units in the caldera walls and on the flanks of the volcano.

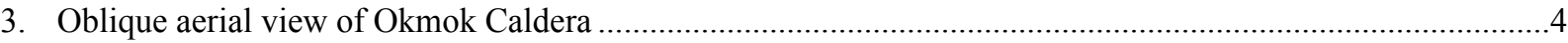

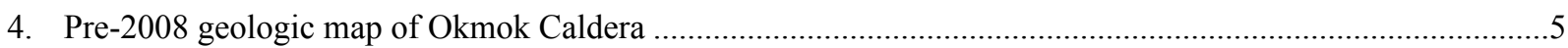

5. Pre-eruption, 2003 oblique aerial photograph of features of Cone D .............................................................

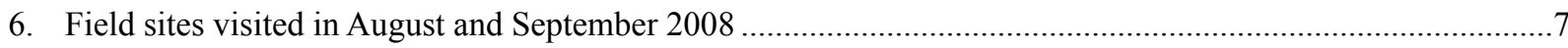

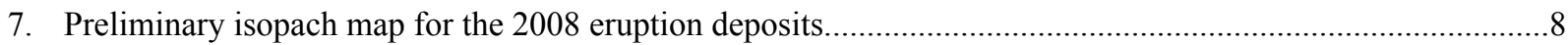

8. Example of lakeshore elevation measurement using Trimble 5700 GPS receiver ...........................................9

9. Representative images of the Okmok eruption plume through the first 12 days of eruption. ...........................10

10. Representative oblique aerial images of the ash plume and vent region through the later part of the eruption

11. Oblique aerial photograph of the eastern margin of Okmok's caldera and lake region from August 2, 2008

12. Sketch map of main eruptive features superimposed on a September 22, 2008, Quickbird satellite image cropped to show the northeastern quadrant of Okmok Caldera.

13. Pre-eruption SAR image of the northeast quadrant of Okmok Caldera …......................................................14

14. SAR images of the northeast portion of Okmok Caldera, July 13-August 28, 2008 ....................................15

15. SAR scenes of the northeast portion of Umnak Island showing all of Okmok Caldera..................................16

16. Oblique aerial view of active vents in Okmok Caldera on August 1, 2008 .................................................18

17. Oblique aerial photographs of North Cone D lake, the new tephra cone Ahmanilix, and West Cone D lake...20

18. Oblique aerial photographs of the 2008 primary tephra cone, Ahmanilix . .21

19. Photographs of Ahmanilix in July and August 2010, showing deeply rilled and eroded flanks.......................22

20. Photographs showing near-surface deposits of the 2008 tephra cone, Ahmanilix.

21. Oblique aerial photograph taken on August 13, 2008, showing the approximate extent of noticeable ballistic fallout around the new tephra cone

22. Comparison photographs of West vent adjacent to the new tephra cone, Ahmanilix.....................................25

23. Oblique aerial photograph of the flank of Ahmanilix and Cone D

24. Oblique aerial photograph showing approximate boundary of the field of collapse pits that formed during the eruption

25. September 15, 2008, photograph showing the interior walls of one collapse crater formed during the 2008 eruption

26. Oblique aerial photograph from summer 2010, showing the approximate zone of original collapse craters. ..27

27. Series of oblique aerial photographs showing the headwaters of Crater Creek, which drains the caldera

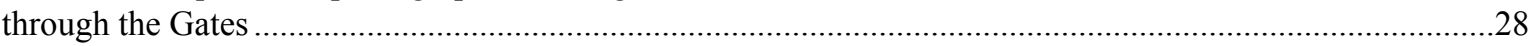

28. Photograph and FLIR image of Ahmanilix crater in 2008

29. Photograph of the Ahmanilix cone in September 2008, showing a "puff" of water vapor emanating from the crater.

30. Oblique aerial photographs and FLIR image of the Cone D lava bench and North Cone D lake shoreline in September 2008 and August 2010

31. Oblique aerial photographs and FLIR images of Cone A through time 
32. August 2010 oblique aerial photograph of the summit craters of Cone A.

33. Oblique aerial views of Cone E lake through time .35

34. Oblique aerial views of Cone $\mathrm{C}$, showing weak summit fumarolic activity through time .36

35. Representative stratigraphic section, showing water-saturated 2008 eruption deposits along the northeasttrending depositional lobe.

36. Likely source of pumice that washed ashore in Unalaska within days of the onset of the 2008 eruption .........38

37. Pre- and post-eruption surface water in the caldera

38. Lake surface elevation measurements from September 2008, plotted on the 2008 Quickbird satellite image

39. Map of lahar deposits in drainages around the flanks of Okmok volcano during and after the 2008 eruption

40. Oblique aerial photographs of dense rill network on upper and medial volcano flanks

41. Oblique aerial photograph taken August 2, 2008, showing the new lahar deposit delta at the mouth of Crater Creek where it empties into the Bering Sea at Cape Tanak on the northern coastline of Umnak Island .42

42. Lahars transported large boulders in the Missouri Creek drainage on the south flank of Okmok .42

43. Oblique aerial view of the 2008 lahar delta at Cape Tanak through time .43

44. Cartoon illustrating our proposed mechanism for pit formation by stoping and collapse due to groundwater withdrawal

\section{TABLES}

Table 1. Summary of eruption type and maximum Volcano Explosivity Index (VEI) at Okmok volcano since the mid-Holocene 



\title{
THE 2008 PHREATOMAGMATIC ERUPTION OF OKMOK VOLCANO, ALEUTIAN ISLANDS, ALASKA: CHRONOLOGY, DEPOSITS, AND LANDFORM CHANGES \\ by
}

\author{
JF. Larsen ${ }^{1}$, C.A. Neal ${ }^{2}$, Janet R. Schaefer ${ }^{3}$, A.M. Kaufman ${ }^{4}$, and Z. Lu $^{5}$
}

\begin{abstract}
Okmok volcano, Aleutian Islands, Alaska, explosively erupted over a five-week period between July 12 and August 23, 2008. The eruption was predominantly phreatomagmatic, producing approximately $0.35 \pm 0.12 \mathrm{~km}^{3}$ (bulk volume) of fine-grained tephra that covered most of northeastern Umnak Island. The eruption had a maximum Volcanic Explosivity Index (VEI) of 4, with eruption column heights up to $16 \mathrm{~km}$ during the opening phase. Several craters and a master tuff cone formed in the caldera as a result of phreatomagmatic explosions and accumulated tephra-fall and surge deposits. Ascending magma continuously interacted with an extensive shallow groundwater table in the caldera, resulting in the phreatomagmatic character of the eruption. Syneruptive explosion and collapse processes enlarged a pre-existing lake, created a second, entirely new lake, and formed new, deep craters. A field of ephemeral collapse pits and collapse escarpments formed where rapid groundwater withdrawal removed material from beneath capping lava flows. This was the first significant phreatomagmatic event in the U.S. since the Ukinrek Maars eruption in 1977.
\end{abstract}

\section{INTRODUCTION}

Okmok volcano, a 10-km-diameter Holocene caldera system in the central Aleutians (Larsen and others 2007; figs. 1 and 2), began a protracted explosive eruption at 1943 UTC July 12, 2008 (Larsen and others, 2009; Neal and others, 2011). Opening explosions consumed a portion of an intracaldera cone (Cone D) in the east-central sector of the caldera, and created a new crater complex in the caldera floor. Eruptive activity began a few hours after onset of a subtle increase in seismicity, followed by a brief earthquake swarm noted only in retrospect. Over the next five weeks, approximately $400 \times 10^{6} \mathrm{~m}^{3}$ of tephra blanketed much of eastern Umnak Island. Inside the caldera, tens of meters of wet tephra, predominantly ash- and lapilli-sized, were deposited by phreatomagmatic explosions from multiple vents. Explosive activity and crater formation disrupted the caldera groundwater system, modifying pre-existing lakes and producing new lakes. Accumulation of pyroclastic surge, fall, and ballistic deposits at the primary vent built a new tephra cone $\sim 300 \mathrm{~m}$ high. Phreatomagmatic eruptions are relatively rare, yet impactful, and this event is the first to occur in the U.S. since Ukinrek Maars erupted in 1977 (Kienle and others, 1980).

This report documents the Okmok eruption by describing vent development and eruptive processes as deduced from remotely sensed imagery, geophysical data, eyewitness accounts, photographs, and field studies. We present a general description of eruption deposits and impacts, and derive an estimate of total eruption volume. This paper also discusses the response of caldera hydrology to the eruption and observations of ongoing fumarolic activity in the caldera. We provide descriptive background for ongoing research on various aspects of the 2008 Okmok eruption (for example, Ort and others, 2012). For additional documentation and analysis of the eruption, including deformation results, readers are referred to summaries in Larsen and others (2009), Neal and others (2011), and Freymueller and Kaufman, (2010). Note that some names of landforms and features in the caldera used in this report differ from usage in Neal and others (2011). This paper capitalizes informal names as an aid to readability.

\section{GEOLOGIC BACKGROUND AND ERUPTIVE HISTORY}

Okmok volcano is located on Umnak Island, $100 \mathrm{~km}$ southwest of Unalaska/Dutch Harbor, in the central Aleutian volcanic arc in Alaska (fig. 1). The Okmok edifice is a gently sloping, $\sim 30-\mathrm{km}$-diameter shield with two $\sim 10-\mathrm{km}$-diameter, nested, Quaternary calderas (Byers, 1959; Miller and Smith, 1987; Miller and others, 1998). The older caldera-forming eruption, Okmok I (Burgisser, 2005), has a ${ }^{14} \mathrm{C}$ radiocarbon age of about 12,000 yBP (Bean, 1999; Begét and others, 2005; Larsen and others, 2007). The younger caldera-forming eruption, Okmok II, has a ${ }^{14} \mathrm{C}$ radiocarbon age of about 2,050 yBP (Larsen and others, 2007). Both caldera-forming eruptions

\footnotetext{
${ }^{1}$ University of Alaska Fairbanks (UAF), Department of Geosciences, P.O. Box 755780, Fairbanks, AK 99775-5780; jflarsen@alaska.edu

${ }^{2}$ U.S. Geological Survey (USGS), Alaska Volcano Observatory, 4230 University Drive, Suite 201, Anchorage, AK 99508-4650; tneal@usgs.gov

${ }^{3}$ Alaska Division of Geological \& Geophysical Surveys (DGGS), Alaska Volcano Observatory, 3354 College Rd., Fairbanks, AK 997093707; janet.schaefer@alaska.gov

4University of Alaska Fairbanks, Geophysical Institute, P.O. Box 757320, Fairbanks, AK 99775-7320; amkaufman@alaska.edu

${ }^{5}$ Southern Methodist University, Roy M. Huffington Department of Earth Sciences, P.O. Box 750395, Dallas, TX 75275-0395; zhonglu@smu.edu
} 


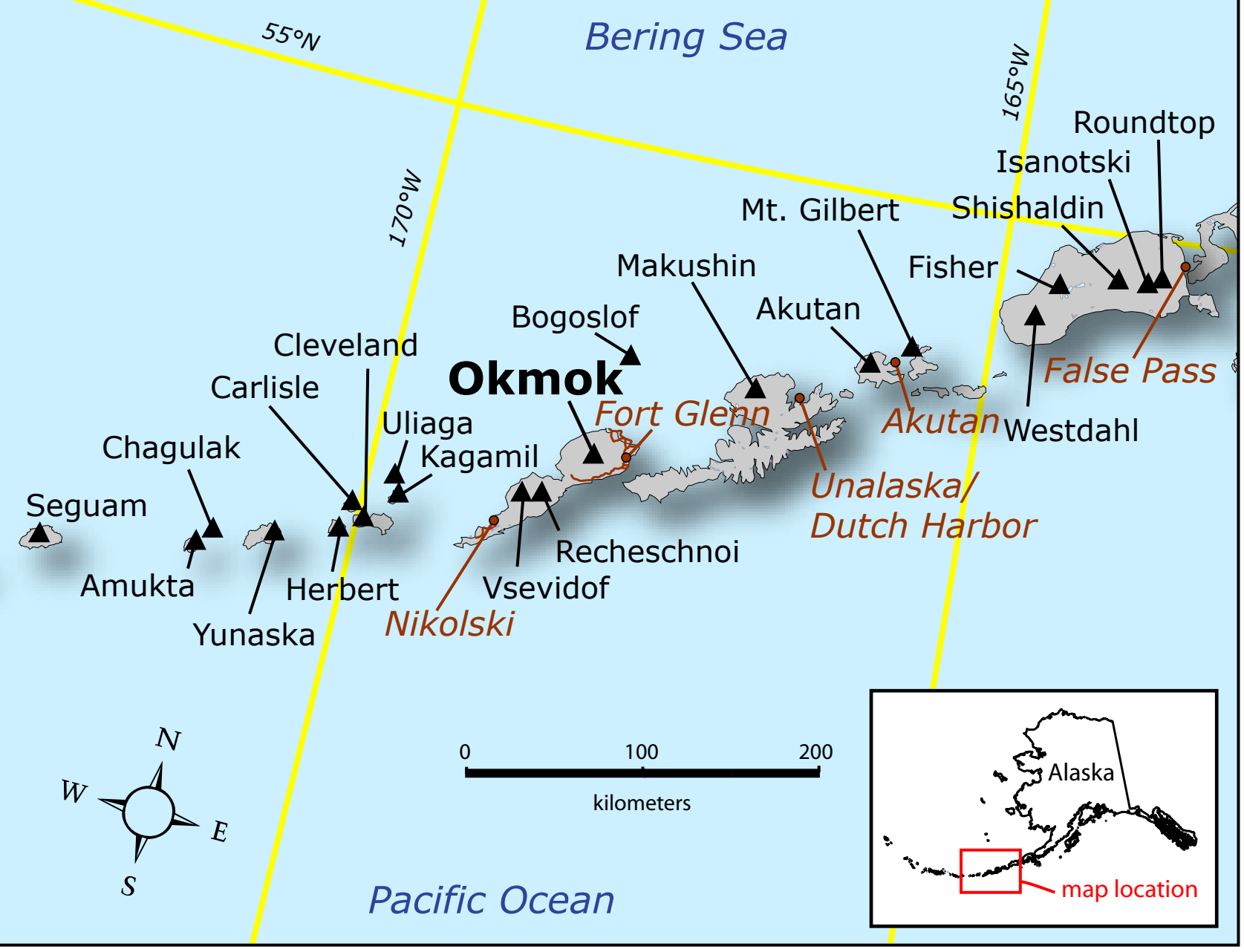

Figure 1. Location of Okmok volcano in the central Aleutian Islands with respect to nearby volcanoes (black triangles) and communities. Okmok is approximately $900 \mathrm{~km}$ southwest of Anchorage.

are notable for a small volume of rhyodacitic to rhyolitic magma erupted early in each eruptive sequence; however, by volume most of the caldera-forming juvenile scoria are basaltic andesite in composition (Larsen and others, 2007).

Before and between the two caldera-forming eruptions, activity consisted largely of basaltic lava effusion, (Byers, 1959; Nye and Reid, 1986; Miller and others, 1992; Kay and Kay, 1994) including the $\sim 2$-million-year-old Ashishik basalt (Bingham and Stone, 1972). A sequence of high-MgO picritic lavas likely older than the Ashishik basalts are exposed along Cape Idak northeast of the caldera (for example, Byers, 1959; Nye and Reid, 1986). More-evolved lava flows and dikes of Pleistocene-Holocene age are exposed inside and outside of the caldera. A Pleistocene glassy rhyolite lava flow, representing the most silicic Okmok magma composition yet found, is exposed high on the north flank of the volcano.

Erupted between the two caldera-forming eruptions, stacked lava flows of the Crater Creek basalt (Byers, 1959) form a bench between Okmok I and Okmok II north caldera walls (figs. 2 and 3). These lavas are well exposed along upper Crater Creek. The Crater Creek basalts were originally named and classified as "basaltic" by Byers (1959), but they range in composition from basalt to andesite (Finney and others, 2008). Between caldera forming eruptions, Okmok also produced a series of scoria-rich fall deposits found on the north, east, and south flanks. The thickest of these, the Middle Scoria, was produced by a violent Strombolian to subplinian, phreatomagmatic eruption (Wong and Larsen, 2010). The relationship of Middle Scoria eruptions to Crater Creek lavas is unknown.

After Okmok II caldera formation, eruptions occurred from at least 12 separate vents in the modern caldera (Begét and others, 2005; Larsen and others, 2009; figs. 2-3). Post-Okmok II eruption styles range from strombolian and hawaiian cinder and spatter cones and associated lava flows to Surtseyan, phreatomagmatic tuff cones and maar craters. Tuff cones consist of thick piles (tens to hundreds of meters) of coarse pyroclastic debris, exhibiting cross-bedding, planar 


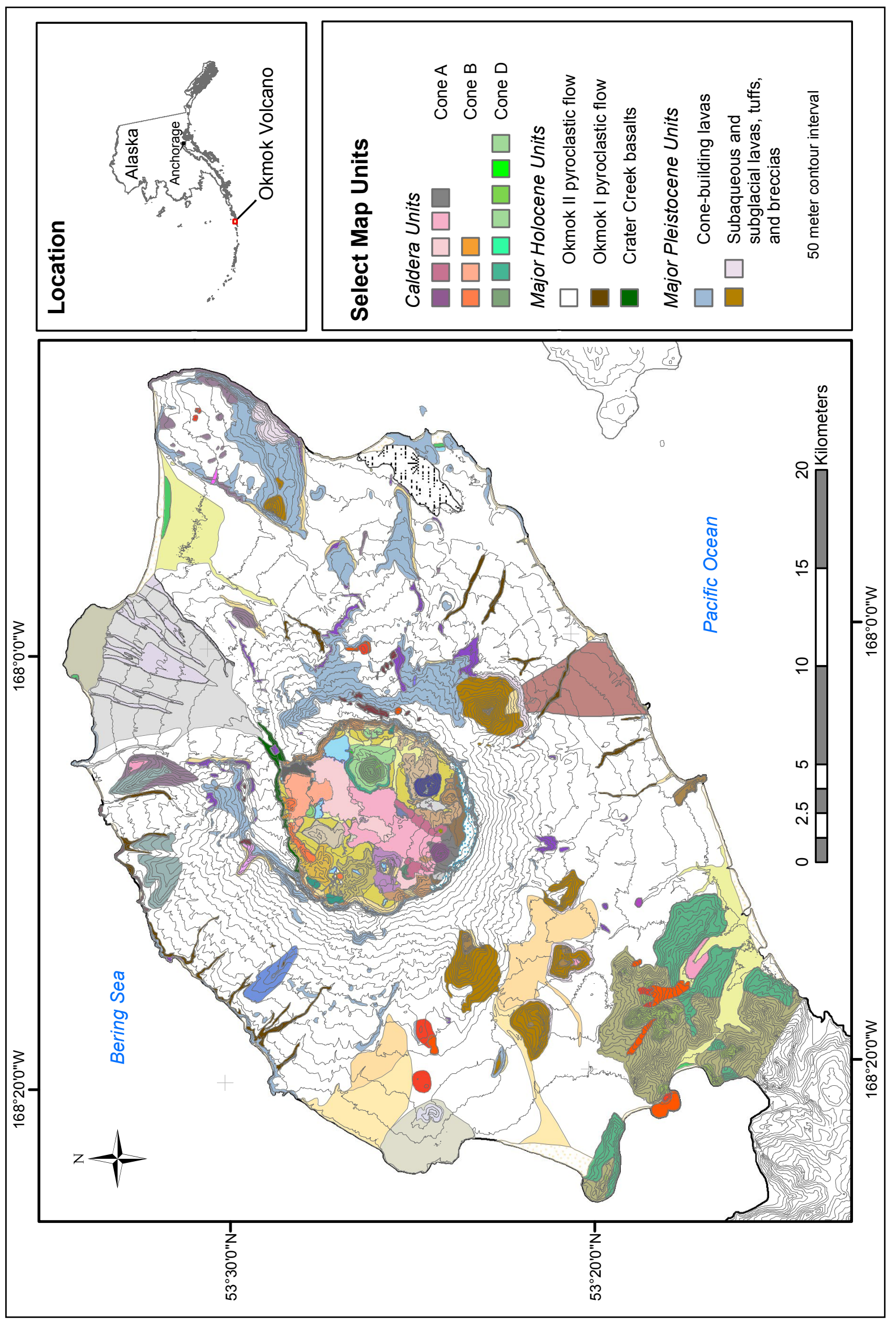

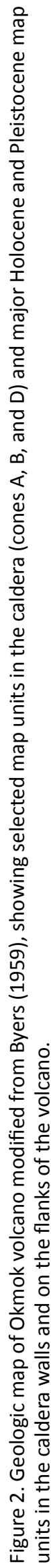




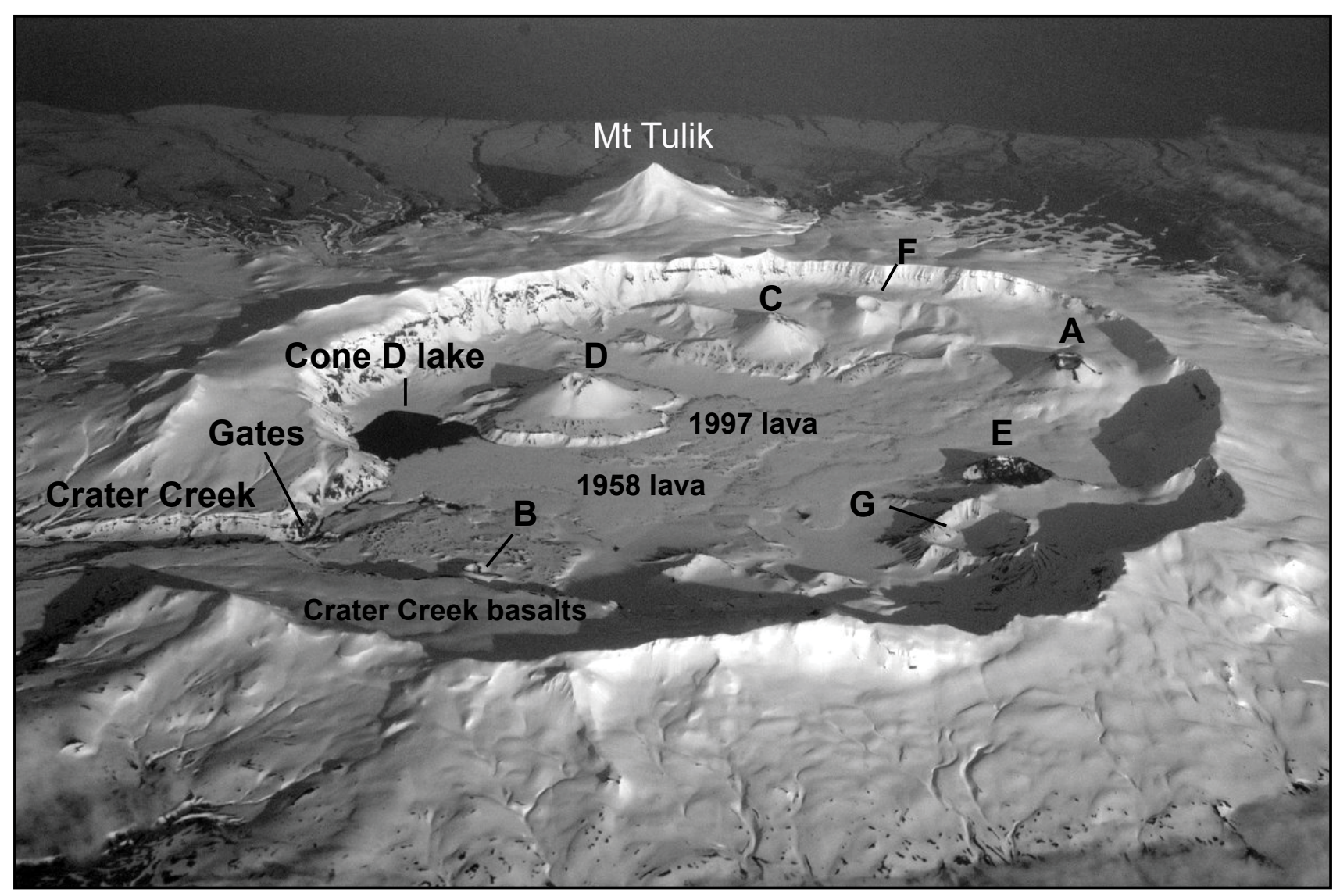

Figure 3. Oblique aerial view, looking to the south, of 10-km-diameter Okmok Caldera. Prominent features are labeled, including major post-caldera cones (letters), 1958 and 1997 lava flows, mid-Holocene Crater Creek basalts, the Gates region, Crater Creek gorge, and the lake adjacent to Cone D (called Cone D lake pre-eruption, it is now referred to as North Cone D lake). Photograph by C. Read (USGS), June 7, 2007.

and massive bedding, interbedded scoria falls, and variably palagonitized zones. Most show evidence of modification by lake shorelines, including rounded profiles, subtle wave-cut benches, or overlying lacustrine clays and sandstones (Begét and others, 2005; C.A. Neal and J.E. Begét, written commun., 2004).Detailed accounts of early historic (defined here as post $\sim 1760$ C.E.) eruptions at Okmok are lacking. According to written records, all eruptive activity since the late 1800 s has occurred at or near Cone A, now a 240-m-high cinder and spatter cone in the southwest quadrant of the caldera (Grey, 2003; figs. 3 and 4). The first well-documented, significant eruptions from Cone A occurred in 1945 and 1958. Both events were largely effusive, producing basaltic-andesite lava flows and locally heavy scoria and ash fall. The most recent pre-2008 eruption at Okmok also occurred from Cone A over a 3.5 -month period in 1997, producing a 10- to 50-m-thick, blocky 'a' a lava flow about $1.54 \times 10^{8} \mathrm{~m}^{3}$ in volume and $5.5 \mathrm{~km}$ in length (McGimsey and Wallace, 1999; Patrick and others, 2003). Ash clouds from this eruption reached more than $6 \mathrm{~km}$ above sea level (ASL), but only minor tephra fall occurred outside the caldera. Between 1958 and 1997, accounts describe additional eruptions producing lava flows, with ash fall as far as Unalaska Island (table 4.1 in Grey,
2003). Field evidence for such events has not been identified. The possibility remains that intermittent, short-lived, small ash eruptions from Cone A occurred, but left little discernible record.

Historically, the 1817 eruption of Okmok appears most similar to the 2008 eruption in terms of eruptive style and mechanism. The 1817 vents extend along a $\sim \mathrm{km}$ arc against the north caldera wall (fig. 4). Phreatomagmatic explosions produced pyroclastic fall and surge deposits extending down the north and east flanks of the volcano (Neal and others, 2003). Later stages of this eruption involved lava fountaining and lava flows from a 120-m-high cinder and spatter cone (Cone B) and subsidiary fissure vents. Blocky 'a'a lava from this eruption fills a shallow basin near the Crater Creek outlet, which drains the caldera through a break in the north wall known as 'the Gates' (fig. 3). Stream terraces and flood deposits outside the caldera record a Crater Creek flooding event associated with the eruption, consistent with historical accounts of coastal Aleut village inundation in 1817 (Grewingk, 1850; Byers, 1959; Wolfe, 2001; Wolfe and Begét, 2002).

Prior to the 2008 eruption, the Okmok Caldera floor consisted of relatively young, fresh lava flows and broad areas 


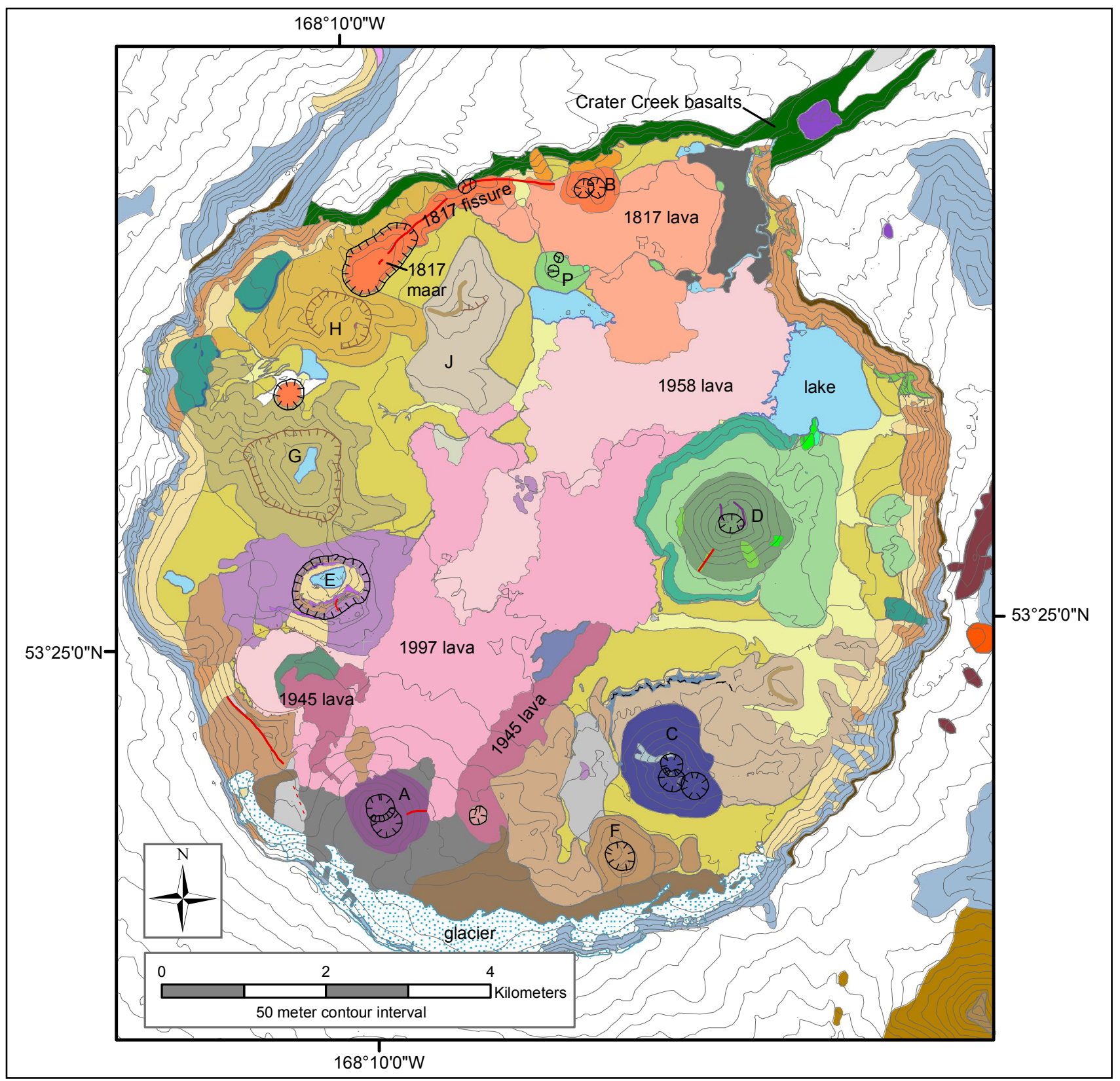

Figure 4. Pre-2008 geologic map of Okmok Caldera with selected map units and vent features labeled (cone letters after Byers, 1959). Thick red lines at the north base of Cone $D$ are an approximation of an area of thermal springs mapped by Byers (1959). These were subsequently drowned by the development of North Cone D lake.

of porous fragmental volcanic sediments forming alluvial fans between topographic highs created by various cones and lava flow fields (Byers, 1959). Active talus and colluvial fans emanating from steep caldera walls and flanks of tall cones were major sources of debris deposited on the caldera floor. A network of permanent and seasonal drainages coalesced into Crater Creek, which exited the caldera through the Gates. Crater Creek was also fed by water draining Cone D lake through and beneath the 1958 lava flow, as well as by thermal seeps emanating from the caldera floor at the north base of Cone D (fig. 5). Principal hydrologic inputs to Crater Creek include long-term runoff from a small $\left(\sim 1.5 \mathrm{~km}^{2}\right)$, debris-covered glacier tucked against the inner southern wall of the caldera (fig. 4), seasonal snowmelt, and occasionally heavy runoff from strong Aleutian storms. The presence of several permanent and recurring ephemeral lakes on the caldera floor indicates an extensive shallow groundwater system in the caldera. 


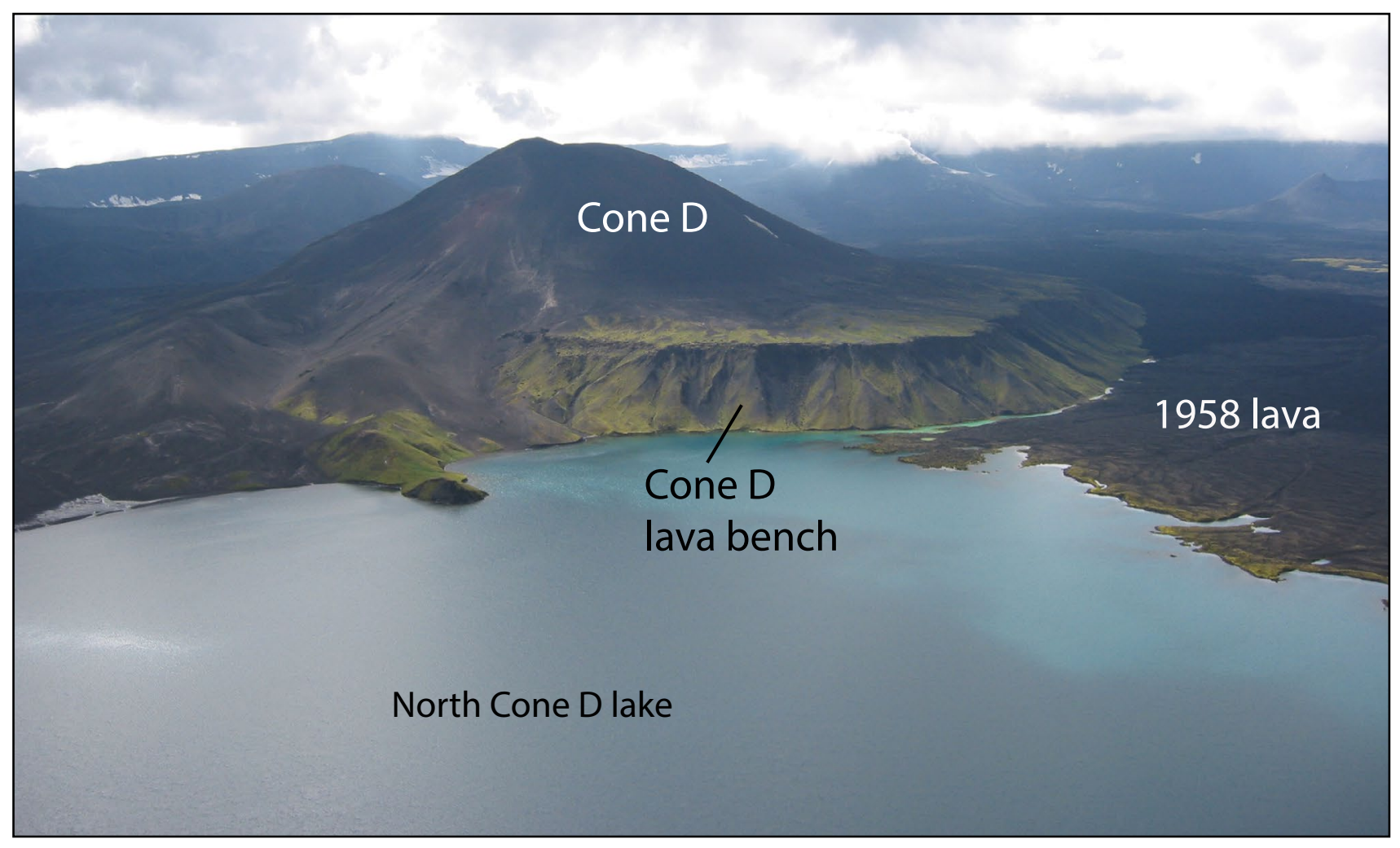

Figure 5. Pre-eruption, 2003 oblique aerial photograph of Cone D, the Cone D lava bench, North Cone D lake, and the toe of the 1958 lava flow, which impounded drainage of the southeastern caldera, forming the lake. View is to the southwest. The summit of Cone D is about $360 \mathrm{~m}$ in elevation above the lakeshore. Photograph by C. Neal (USGS), 2003.

\section{METHODS}

\subsection{Geologic observations, sampling, and eruption volume estimates}

In response to the 2008 eruption, the Alaska Volcano Observatory (AVO) sent field teams to Okmok from July 31 through August 3, 2008, and from September 8 through 15,2008 . Teams gathered helicopter- and ground-based observations, documented new volcanic features and lake changes, and described stream-channel and shoreline modifications created by widespread lahar inundation. Samples and stratigraphic descriptions were collected at 50 locations in the caldera and on the volcano flanks (appendix A, fig. 6). Juvenile scoria and pumice were hand picked for geochemical analysis and bulk samples of ash were collected for granulometry and componentry. Where possible, measured-area samples of tephra-fall deposits were taken to derive mass per unit area (MPUA) data.

Tephra thickness measurements and estimated thicknesses were compiled as an isopach map of the on-island deposits (appendix A, fig. 7). Estimates of total bulk and dense-rock-equivalent (DRE) eruptive volumes were calculated following the methods of Fierstein and Nathenson (1992) and Pyle (1989), assuming exponential decay of thickness with distance. Using this approach, eruptive volumes were estimated using the two-line-segment method derived from plotting deposit thickness on a logarithmic scale against the square root of isopach areas $\left(\mathrm{A}^{1 / 2}\right)$. Bulk eruptive volume was then converted to DRE by correcting for bulk ash density. Bulk ash density was estimated in the lab using dried and weighed MPUA samples of bulk ash collected on-island.

\subsection{Lake surface elevation measurements and volume estimates}

Lake surface elevations in the caldera on September 15, 2008, were measured using a Trimble 5700 survey system (fig. 8). We placed a Zephyr Geodetic antenna as close as possible to waterline and recorded data at 30 -second intervals for a minimum of 15 minutes. Where the lakeshore was inaccessible, we used an Impulse 200 laser rangefinder to estimate vertical offset between the lake and GPS antenna (site OLL8). No permanent monuments were installed. Global Positioning Satellite (GPS) data were processed in GNSS-inferred positioning system (GIPSY) software using a local network of concurrently operating temporary and continuous GPS sites on Okmok volcano (stations OKCE, OKFG, OKSO, OK13, OK31, and OK37; Freymueller and Kaufman, 2010). This gave better results than using the National Geodetic Survey's on-line processing service (OPUS) and its distal reference stations. Lake surface elevations are given as ellipsoid height (ITRF 2000).

To determine the volume of the pre-eruption North Cone D lake, we digitized pre-lake basin topography from 


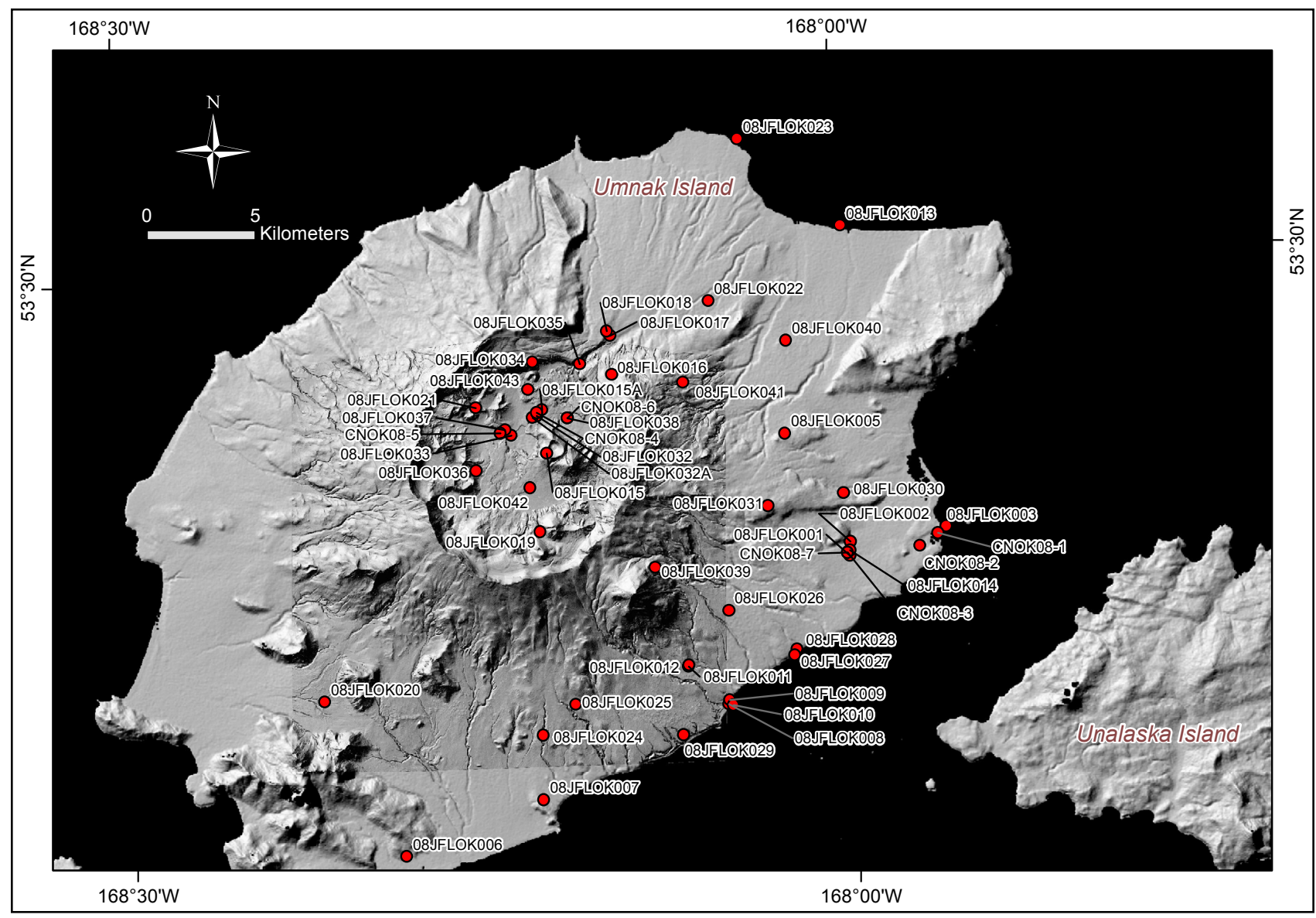

Figure 6. Field sites visited in August and September 2008. The shaded-relief base map combines DEM data from 2000 (Schaefer, 2005) with the additional overlay of a more detailed shaded relief in the caldera derived from a DEM created from January 21 , 2010, Worldview imagery (Schaefer and others, 2011). Additional field sites on Unalaska Island (table 1) are outside of this map area. Location of the Fort Glenn ranch house is also shown.

Army Map Series topographic map Umnak Island 7 Q831. This 20 -ft-contour topographic map was compiled by photogrammetric methods from 1943 aerial photography, pre-dating the 1958 lava flow that created the Cone D lake. The pre-2008 shoreline was digitized from IKONOS satellite imagery acquired in 2000. AirSAR imagery acquired October 17, 2000, gives a pre-eruption lake surface elevation of $\sim 378 \mathrm{~m}$. Using the calculated lake bathymetry, the 2000 shoreline and 2000 lake elevation, a triangulated irregular network (TIN) three-dimensional (3-D) model of the pre-eruption lake was constructed in ArcMap, and the pre-eruption lake volume was determined using Arc 3-D Analyst's cut-and-fill tool of the TIN below $378 \mathrm{~m}$.

\subsection{Synthetic Aperture Radar (SAR) analysis}

Okmok is remote, thus we have few direct observations of the eruption. Furthermore, the eruptive plume and weather clouds created nearly constant obscuration of the vent region and also hampered optical satellite image tracking of the eruption. Synthetic Aperture Radar (SAR) is mostly unaffected by weather clouds and volcanic ash. A SAR image includes both the intensity and phase components of the backscattered radar signal from each ground resolution cell (Lu and Dzurisin, 2014). Applications of SAR in past Okmok studies focused on surface deformation (due to magmatic activity and thermoelastic contraction of lava flows) using SAR backscattering phase signal through interferometric analysis (for example, Lu and Dzurisin, 2010; Lu and others, 2000). We utilize SAR backscatter intensity images to track surface modification during the course of the 2008 eruption. SAR images were acquired from European Space Agency's Envisat satellite, a C-band sensor with a wavelength of $\sim 5.6 \mathrm{~cm}$. In general, SAR backscatter intensity represents the radar reflectivity of the ground surface, and is determined primarily by the terrain slope, surface roughness, and dielectric constant. SAR is a side-looking sensor and therefore the imaged surface is distorted. Although SAR images used here were obtained from different satellite tracks with different view geometry, in section 4.2 we compare each co-eruption image with the average pre-eruption intensity image of the same track ('same view geometry'). This procedure minimizes the SAR geometric distortion and facilitates change detection. Terrain-corrected and georeferenced SAR images including delineated features caused by the 2008 eruption were 


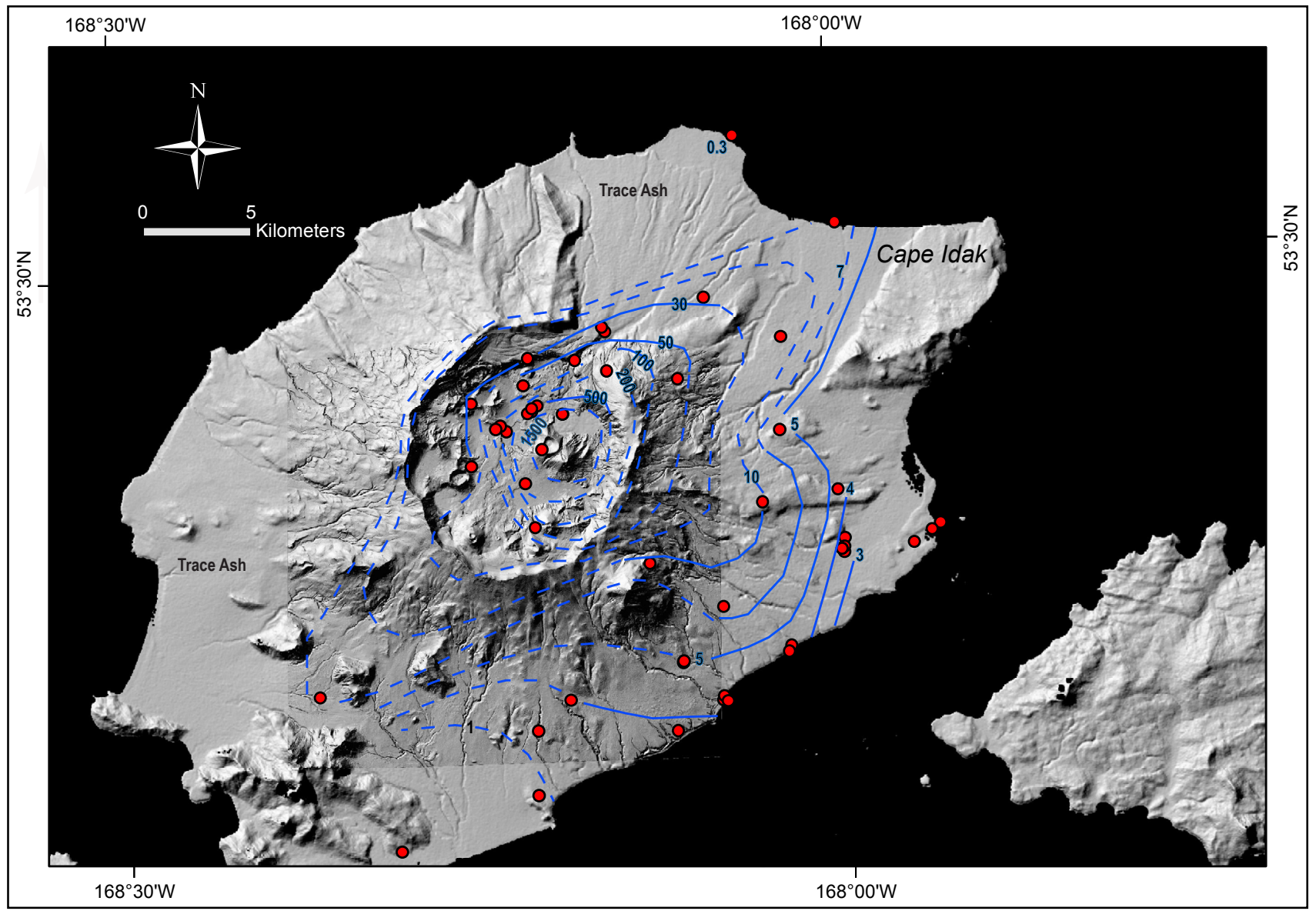

Figure 7. Preliminary isopach map for the 2008 eruption deposits, compiled from reconnaissance measurements in September 2008. Solid lines are isopachs in centimeters; isopachs are dashed where inferred or highly uncertain. Red dots indicate location of ash thickness measurements. The figure shows three primary lobes of deposition to the northeast, southeast, and southwest corresponding to primary wind directions over the course of the eruption. 'Trace ash' in areas north and southwest of the caldera indicate regions where ash was visible on the surface but typically in discontinuous patches with total thickness less than 1 mm.

imported into ArcGIS and compared with other geospatial data sets including a pre-eruption DEM, geologic mapping, and post-eruption Quickbird satellite imagery. Using a series of images spanning the timeframe of the eruption, we have interpreted the evolution of vents and other features during the course of activity.

\section{RESULTS}

\subsection{Eruption chronology}

The 2008 eruption of Okmok volcano began abruptly and with little warning. Seismicity began to increase slightly at 1436 UTC July 12, about five hours prior to the onset of vigorous eruption (Larsen and others, 2009; Neal and others, 2011). A clear increase in small, volcano-tectonic earthquakes began about an hour prior to the onset of continuous tremor; this tremor likely marked the start of the explosive eruption at 1943 UTC. Strong seismicity and accompanying ash emission were soon confirmed by eyewitness accounts and satellite data. Tremor intensified at 1948 UTC and remained vigorous for more than ten hours during the strongest phase of the eruption, after which ash production and seismicity began to decline. Prevailing winds carried most of the initial eruption cloud to the east and southeast, depositing more than $1 \mathrm{~m}$ of coarse ash and lapilli along the caldera rim and $8 \mathrm{~cm}$ at the coast, $17 \mathrm{~km}$ downwind. During the first hours of the eruption, eyewitnesses at Fort Glenn ranch (10 km from the caldera rim; fig. 6) reported constant ground shaking, roaring, rumbling, and flashes of lightning from the direction of the volcano. Ash fall at Fort Glenn was described as wet sand mixed with occasional pebble-sized fragments. By 2212 UTC, the ash cloud extended eastward over Unalaska Island.

AVO was first notified of the eruption on July 12 by U.S. Coast Guard (USCG) staff, who had been contacted by Fort Glenn caretakers who were evacuating the island. AVO quickly issued a formal notice of the eruption, declaring Aviation Color Code RED and Volcano Alert Level WARNING (see code definitions in Gardner and Guffanti, 2006) and commenced 24-hour onsite operations at the AVO office in Anchorage.

Following the opening phase on July 12, the volcano continued to erupt plumes of varying intensity and ash 


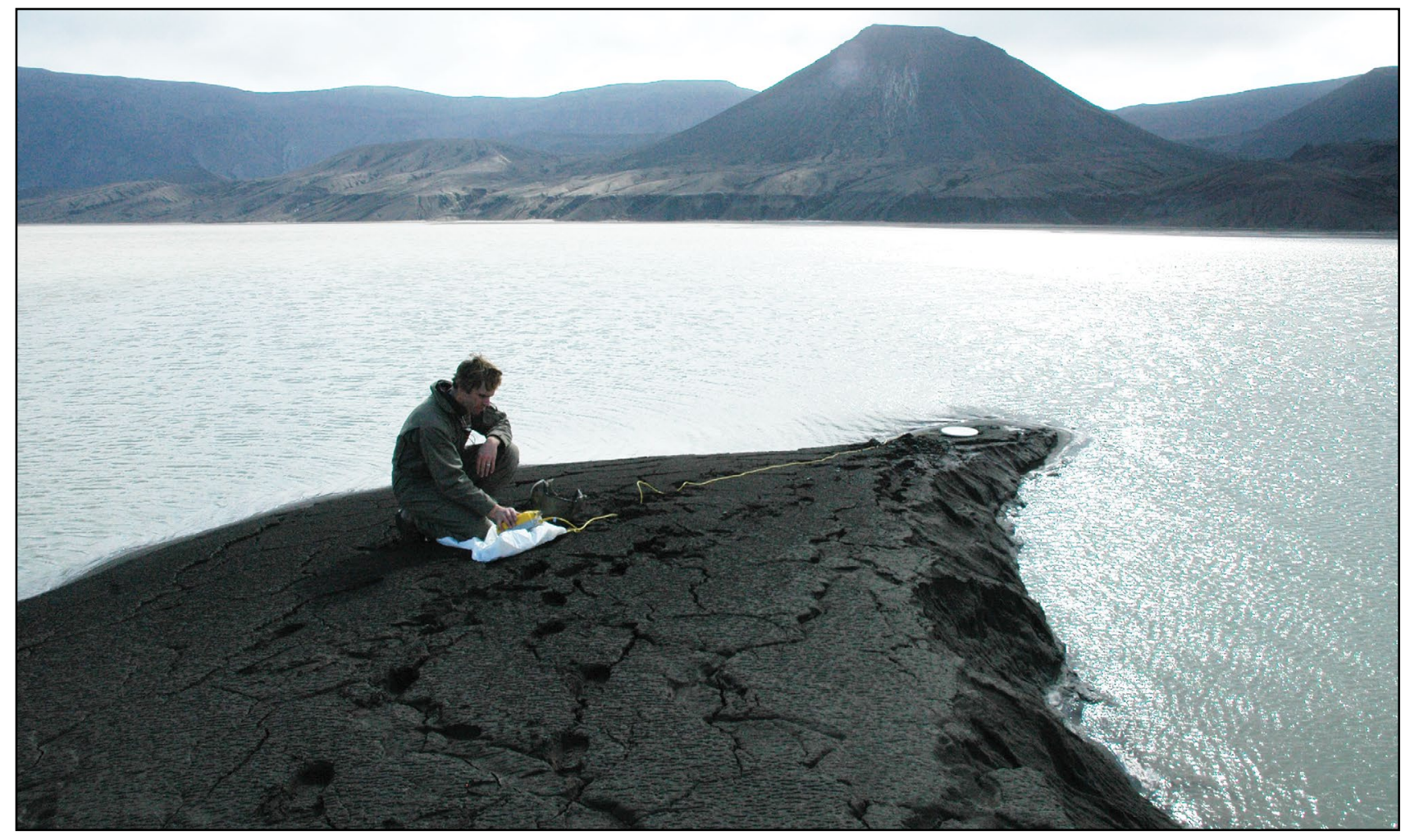

Figure 8. Example of lakeshore elevation measurement using Trimble 5700 GPS receiver. View is to the south across an ephemeral lake created between cones $\mathrm{D}$ and $\mathrm{C}$ during the 2008 eruption. Cone $\mathrm{C}$ is the prominent cone across the lake. Max Kaufman, UAF geophysicist, in foreground. Photograph by J. Larsen (UAFGI), September 2008.

content that day. Ash cloud heights occasionally exceeded $9 \mathrm{~km}$ ASL, but more often remained below about $8 \mathrm{~km}$. On July 13 , a satellite view of the island showed a vent area in the northeast quadrant of the caldera. Two distinct plumes emanated from the caldera; one plume, at a lower altitude, was ash-rich and brownish gray and another, higher plume was ash-poor and white (fig. 9). Oblique aerial photos from a passing jet on July 13 also confirmed a broad zone of venting in the northeast sector of the caldera. The most energetic eruption column was a mixture of ash and significant amounts of water vapor; roiling, light gray-brown clouds of ash traveled at low velocity across the caldera floor upwind and away from the base of the main eruption column. Because of the broad, obscuring eruption column, it was difficult to discern the number of discrete vents (see section 4.2).

On July 23, Fort Glenn rancher Lonnie Kennedy returned to the island and photographed eruption impacts, continuing ash emission, and ash fall in the vicinity of the caldera. Channels of muddy water crossed the lowlands surrounding the ranch. Lahars in several drainages north of the ranch destroyed wooden bridges and culverts and caused severe bank erosion. Significant new lahar-deposit deltas formed at the mouths of creeks draining the northeast and southeast flanks of Okmok. Overbank deposits and the presence of large boulders atop the lahar-deposit fan at the mouth of Crater Creek indicate temporarily high discharge rates sometime early in the eruption (see section 4.7). Photographs on July 24 from Fort Glenn showed a dominantly white cloud containing little ash (fig. 9C); aerial observations of the caldera that day confirmed that ash was still erupting from multiple sources on the caldera floor.

Brief periods of increased tremor amplitude accompanied by higher and more ash-rich eruption clouds were recorded between July 28 and August 3, when an AVO science team was on-island. On August 2, AVO scientists noted that the locus of ash emission migrated from southwest to northeast over the course of several minutes. Eruption columns of variable ash content ascended as high as $3 \mathrm{~km}$ above the vent (fig. 10) and continued to rise buoyantly as they drifted downwind (fig. 20 in Neal and others, 2011). Adjacent, distinct water-vapor- and ash-dominated columns suggested at least two active vents. Closer views from a helicopter revealed that by August 2, North Cone D lake was drastically reduced in areal extent; deeply gullied sediments formerly below lake level were now exposed (fig. 11). Winds, which had been predominantly westerly and northwesterly for the first few weeks of the eruption, switched to northeasterly in late July and early August, sending ash to the southwest.

Ash production increased on August 3 (fig. 10B), prompting the Kennedy family to self-evacuate from Fort Glenn ranch for a second time. Observations from onsite AVO personnel, commercial aircraft, and satellite imagery on this day indicated an ash-rich cloud rising between 7 and $12 \mathrm{~km}$ ASL. 
Figure 9. Representative images of the Okmok eruption plume through the first 12 days of eruption. A. July 13, 2008, MODIS satellite image showing eruption plumes extending southeastward over the Pacific Ocean. NASA image courtesy MODIS Rapid Response team and the NASA Earth Observatory. B. July 21, 2008, oblique aerial photograph showing the eruption plume emanating from a broad region on the caldera floor. View is from a U.S. Coast Guard aircraft at approximately 20,000 $\mathrm{ft}$ altitude northeast of the caldera. Photograph by C. Neal (USGS). C. July 24, 2008, photograph from Fort Glenn, approximately $14 \mathrm{~km}$ east of the vent. Photograph by L. Kennedy, used with permission.
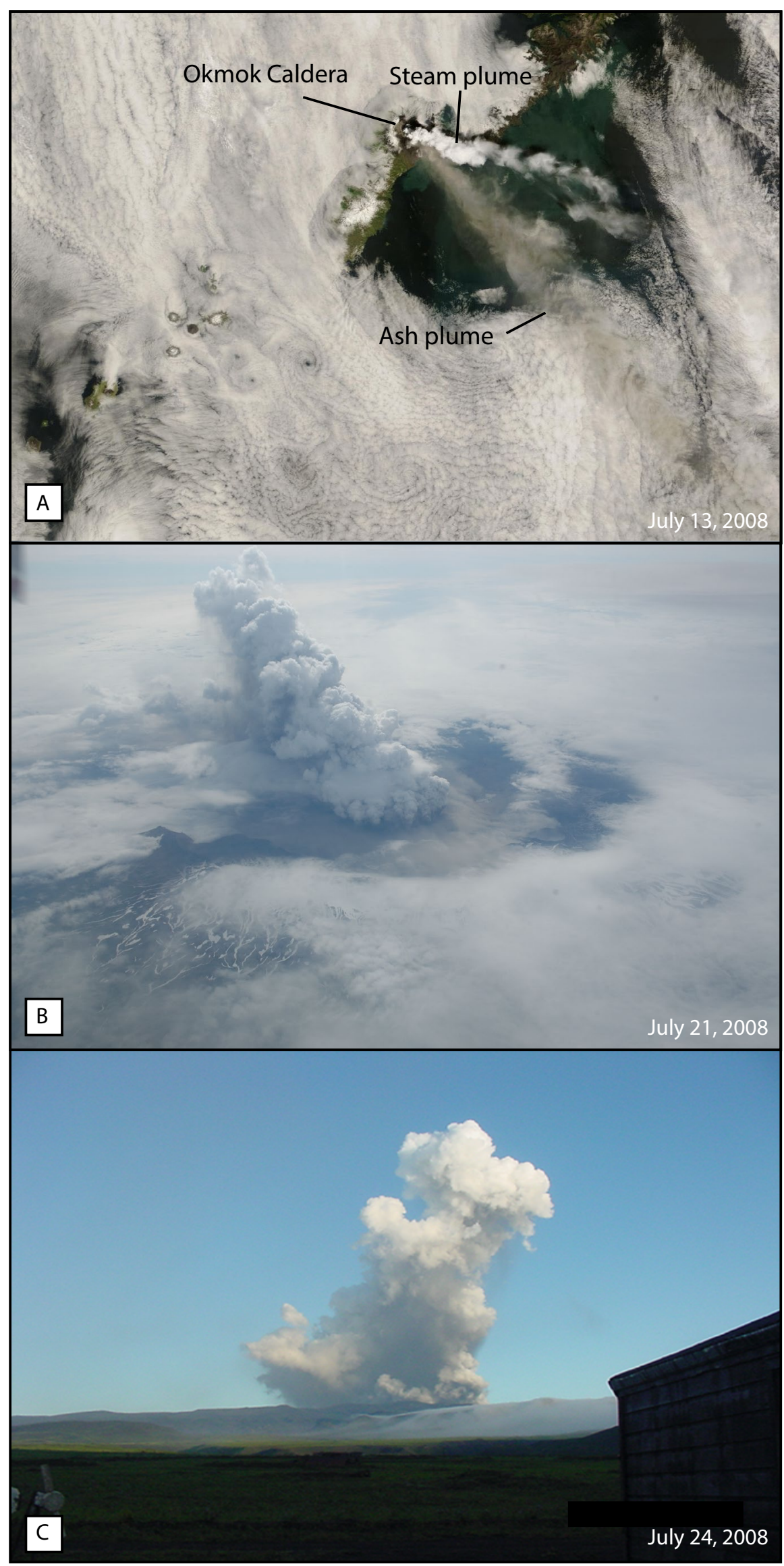


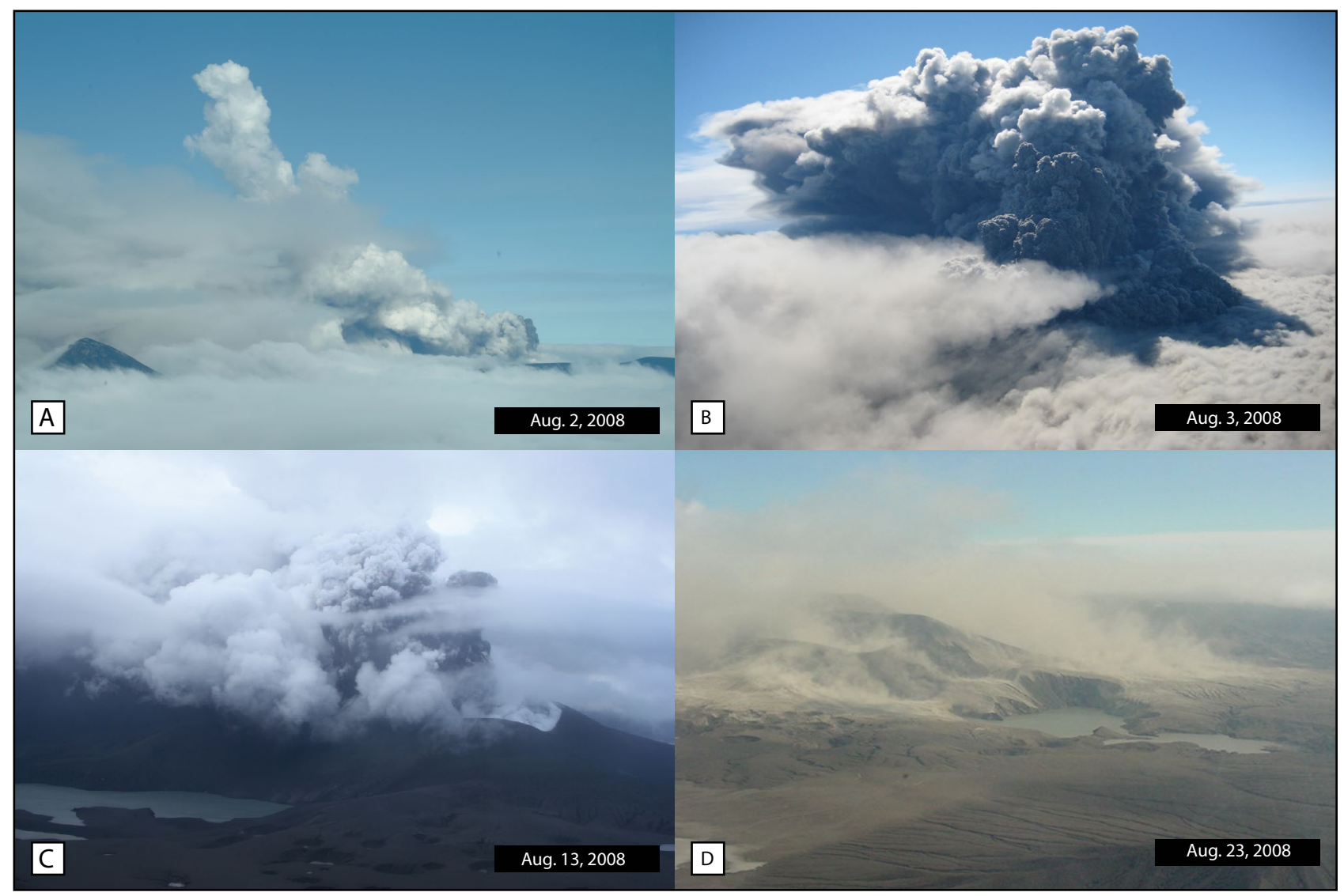

Figure 10. Representative oblique aerial images of the ash plume and vent region through the later part of the eruption. A. August 2, 2008, photograph of a 3-km-high, ash-poor plume; view is to the northwest. Photograph by J. Schaefer (DGGS). B. August 3, 2008, photograph from above the northern caldera rim. The eruption cloud height (estimated from satellite imagery) varied between 7 and $12 \mathrm{~km}$ ASL on this day (Larsen and others, 2009). Photograph by G. Tytgat (UAFGI). C. August 13, 2008, photograph showing a low, roiling eruption column emerging from the new tephra cone Ahmanilix (see text for explanation of name). Photograph by C. Hults (USGS). Plume heights (estimated from satellite imagery) during the waning days of the eruption were generally less than $4 \mathrm{~km}$ ASL (Larsen and others, 2009). D. August 23, 2008, photograph showing light tan ash blowing around the caldera with no eruptive activity. Photograph by L. Kennedy, used with permission.

Following the increased activity in early August, eruption intensity and cloud height gradually diminished. USGS geologists entered the caldera by helicopter on August 13, about six days before the end of the eruption, and photographed a single active vent enclosed within a steep-sided tephra cone on the northwest flank of Cone D (fig. 10C). Dark clouds of ash, surrounded by a collar of lighter-colored ash and water vapor, boiled out of the center of the tephra cone; northwesterly winds sent an ash and water vapor cloud over the summit of Cone $\mathrm{D}$ and the caldera rim. A significant lake had returned to the site of the pre-eruption North Cone D lake, and the landscape was completely covered with grey-brown ash. Numerous circular pits several meters to several tens of meters in diameter pocked the caldera floor north of Cone D. A series of craters with scalloped margins extended in a line west of Cone D; one hosted a new standing body of water now called West Cone D lake. Exactly when ash emission ceased is uncertain; the last satellite-detected airborne ash signature during a period of above-background seismicity was
August 19, and no ash emission was observed during a flight into the caldera on August 23 (fig. 10D). August 19 is defined as the end date of the eruption by Neal and others (2011). For the next several weeks, seismicity remained low with bursts of higher-amplitude tremor but no further emissions of ash were verified. Occasional thermal anomalies were visible in satellite images, likely caused by the still-warm vent area, fumaroles, and/or solar reflection from caldera lakes. Rapid eolian reworking of fine-grained tephra resulted in light tan ash lofted from dry surfaces (fig. 10D).

\subsection{Vent development and SAR analysis}

Tephra was emitted from multiple vents that developed over the course of the eruption, ultimately producing a 2-km-long, east-west-oriented line of maar-like craters and a master tephra cone (fig. 12). The easternmost vent opened just west of North Cone D lake and north of Cone D. The longest-lived and most productive 2008 vent produced a $\sim 300$-m-high tephra cone perched on the northwest shoulder 


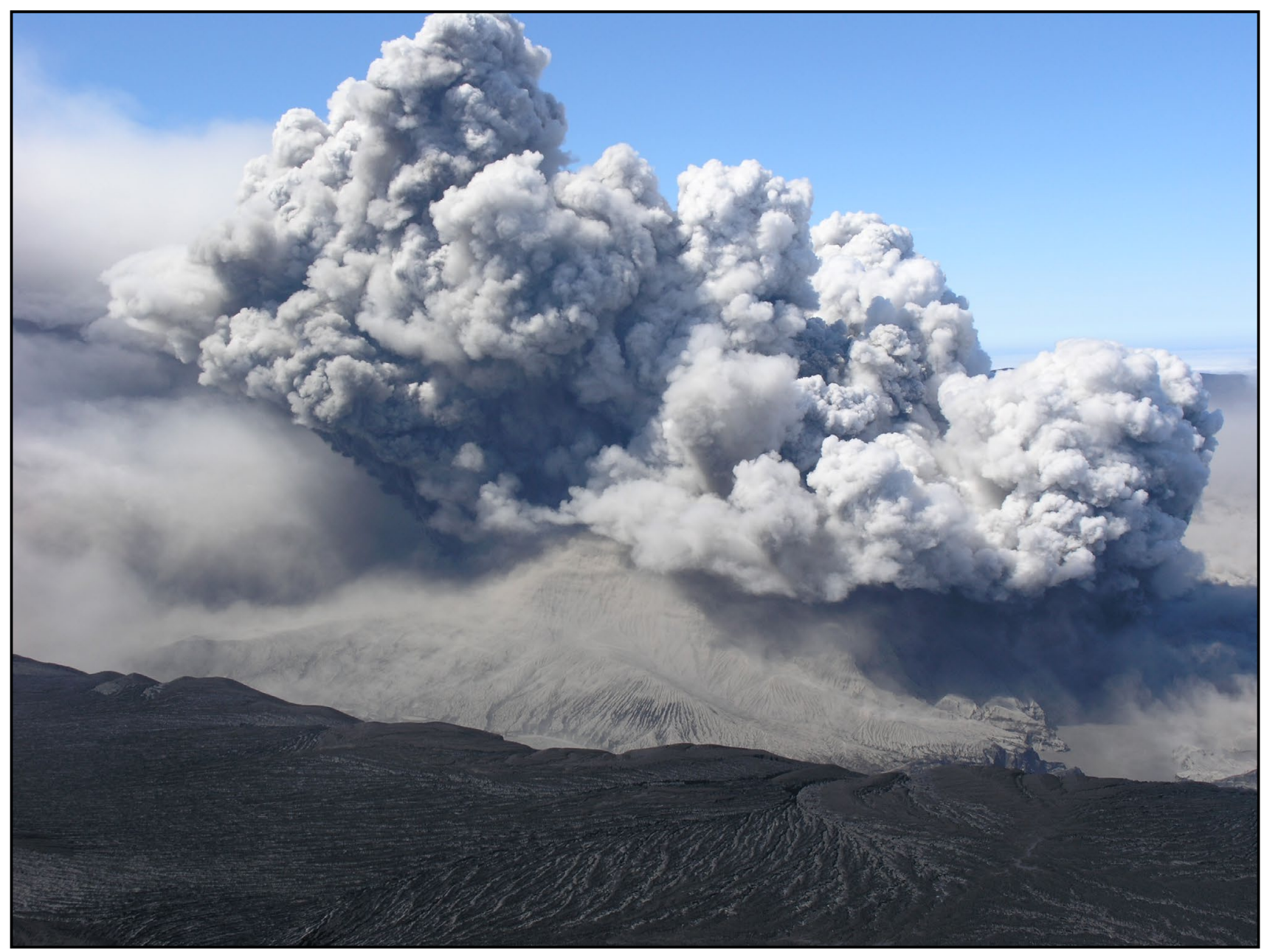

Figure 11. Oblique aerial photograph of the eastern margin of Okmok's caldera and lake region from August 2, 2008; view is toward the west. Ash is erupting from vents to the north and west of Cone D. The dark foreground is the ash-covered caldera rim and the dusty tan region in the lower right corner shows standing water in the general area of North Cone D lake. Newly exposed bedded volcaniclastic, lacustrine, and alluvial sediments are visible in the lower right. Deep rills cut into 2008 tephra on the flank of Cone D are visible just below the cloud at lower center of image. Photograph by J. Schaefer (DGGS). AVO image database: https://www.avo.alaska.edu/images/image.php?id=14700

of Cone D. This new tephra cone is informally named Ahmanilix, an Atkan dialect name meaning 'surprise', suggested by Native Alaska language expert Moses Dirks (written commun., 2008). To the west, at least two vents mark the site of explosions through the caldera floor and subsequent tephra emission: a steep-walled, asymmetric tephra ring (West vent, fig. 12) that partially excavated the side of Ahmanilix and a water-filled maar farther to the west (New Lake vent, fig. 12). An additional crater west of New Lake vent (black star enclosed by queried red dashed line in fig. 12) may not have been a site of tephra emission. Arcuate escarpments outboard of the vent regions, now forming shorelines of post-eruption lakes, were formed by collapse of the ground surface and were not active sites of ash emission.

In section 4.2.2, we describe vent development, integrating information from multiple sources including SAR imagery, aerial observations and photographs, and inferences from field observations and mapping in September
2008. Details of early vent geometry and characteristics may have been lost due to rapid modification and tephra burial of surfaces between available SAR images. Additionally, radar-backscatter properties are a complex function of terrain slope, moisture, grain size, incidence angle, and polarization, making unique interpretation difficult. Finally, the lack of a time-correlative DEM for each SAR image introduces distortion in the image, so locations and mapping of rapidly changing landscape features are approximate.

\subsubsection{Pre-eruption setting}

The 2008 eruption occurred in the northeast quadrant of the caldera, a region that previously contained only one post-caldera vent, Cone D (figs. 3, 4, and 13). Cone D is a 300-m-high cinder and spatter cone atop a steep-sided lava bench (fig. 5); Cone D formed by subaqueous and subaerial eruption when a large lake filled much of the caldera in early post-caldera time (Byers, 1959; Almberg, 2003). Radiocarbon 


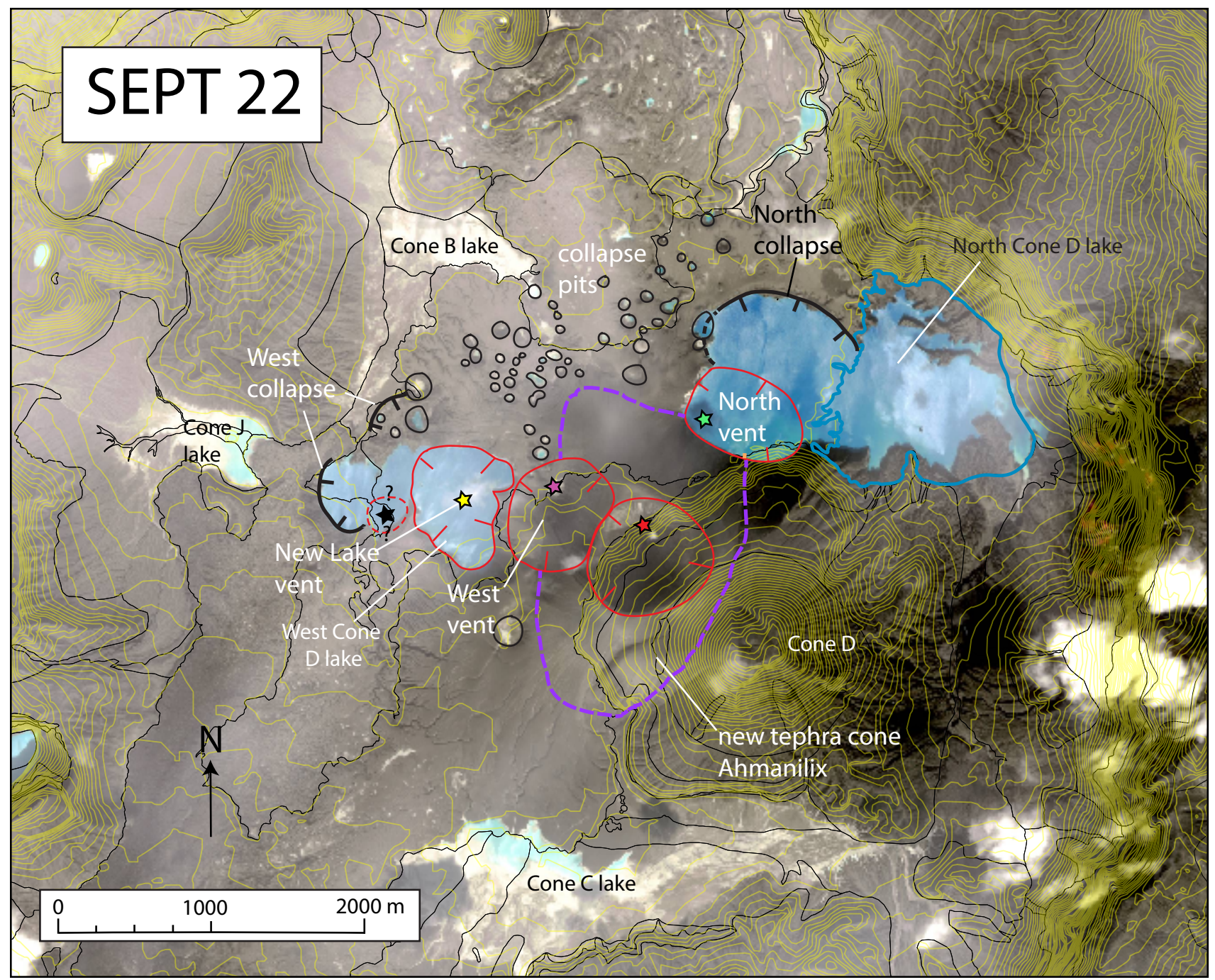

Figure 12. Sketch map of main eruptive features superimposed on a September 22, 2008, Quickbird satellite image cropped to show the northeastern quadrant of Okmok Caldera. Yellow linework represents 10-m-contour pre-eruption topography. Blue line is the shoreline of Cone D lake pre-eruption; note extent of formerly submerged material exposed one month after the eruption ended. At time of image acquisition, North Cone D lake had drained and was in the process of refilling. Purple dashed line shows the approximate extent of thick deposits forming the new tephra cone, Ahmanilix. Red hachured lines trace rims of main vent craters, queried where highly uncertain. Stars note inferred position of primary vents (compare to pre-eruption SAR image, fig. 13). Thick black hachured lines indicate major collapse scarps; thin black lines outline craters interpreted as collapse pits, north of the vent area. Faint black lines define geologic units.

dating of tephra tentatively correlated with Cone D suggests an age of about $1 \mathrm{ka}$ for its last eruption (J. Begét, written commun., 2004). Prior to 2008, Cone D was surrounded on the north and west by blocky 'a'a lava flows from Cone A eruptions in 1958 and 1997. Northeast of Cone D, North Cone D lake was created when the 1958 lava flow impounded drainages between Cone $\mathrm{D}$ and the caldera wall; to the south and east were an active alluvial basin and older volcaniclastic deposits (fig. 4). Weak thermal springs along the north base of Cone D (fig. 13) - subaerial in the 1940s when described by Byers and others (1947) — had been drowned by the formation of Cone D lake in 1958, but were still active when last examined in 2001 by AVO field geologists.

\subsubsection{Opening phase}

Figure 14 presents a series of panels (A-F) that pair preeruption SAR views with a sequence of identical orbit and look-angle images for the caldera floor over the course of the eruption. The first post-eruption SAR image on July 13 (08:40:53 UTC), about 13 hours into the eruption, shows a broad zone of disruption extending about $2 \mathrm{~km}$ on and adjacent to the northwest flank of Cone D (red annotation, lower panel of fig. 14A). In this zone, we identify several circular features with diameters of about $100-300 \mathrm{~m}$ as possible vents or explosion craters that modified the Cone D lava bench and adjacent caldera floor. The northeastern margin of the disrupted zone is within about $500 \mathrm{~m}$ of the North Cone D 


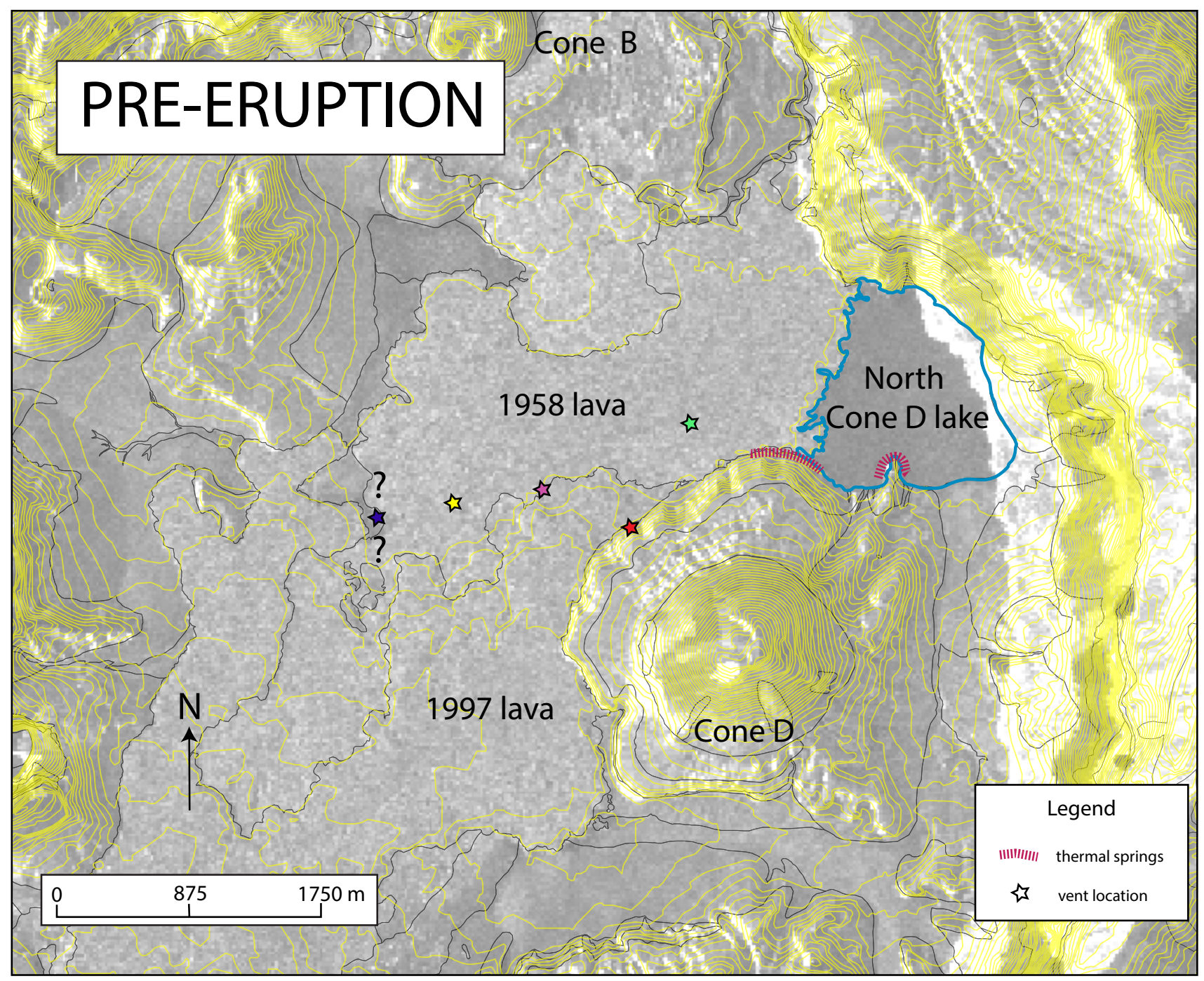

Figure 13. Pre-eruption SAR image of the northeast quadrant of Okmok Caldera. Yellow linework represents 10-m-contour preeruption topography, and faint black lines define geologic units. Principal pre-eruption features relevant to this paper are labeled. Stars are as shown in figure 12 and represent approximate positions of the primary vents for the 2008 eruption. Thick magenta hachured lines along a portion of the base of Cone D indicates areas of weakly thermal springs described by Byers (1959).

lakeshore. A July 13 MODIS image shows distinct ash-rich and water-rich plumes above the eruption site (fig. 9A); we suggest that these two plumes may reflect simultaneous activity from a 'dry' vent or vents through the northwest flank of Cone D and a 'wet' vent or vents closer to the caldera floor. An oblique aerial photograph taken late in the afternoon of July 13 of the broad eruption column also shows a more ash-rich but lower plume rising above the western vent region while the adjacent eruption column is lighter in color and ascends to much greater altitude.

To the northwest of Cone D on the 1958 lava surface, two parallel linear features and several other distinct reflectors on the July 13 image (short red lines, lower panel of fig. 14A) may represent ground cracking or other surface disruption related to the explosive eruption onset 13 hours earlier. Tephra accumulation on the first day of eruption had already modified the blocky surface texture of the 1958 and 1997 lava fields north and west of Cone D, reducing the strong radar-reflectivity of the pre-eruption surface with increasing tephra cover. Satellite images and mapping of the fallout from the opening phase of July 12 and into July 13 show a dominant northeastward-to-southeastward trajectory for the bulk of fallout (J. Unema, written commun., 2011). Tephra accumulation to the northwest of the vent area may reflect additional accumulation from pyroclastic surges and fallout related to explosive opening of vents on the caldera floor.

By July 16, four days into the eruption, SAR imagery shows an expanded zone of disruption (figs. 14B and 15). The exact number of individual craters present is unclear, but compared to July 13, circular features with diameters of up to $500 \mathrm{~m}$ are visible farther to the west of Cone D. We interpret these as the opening of additional vents, or 

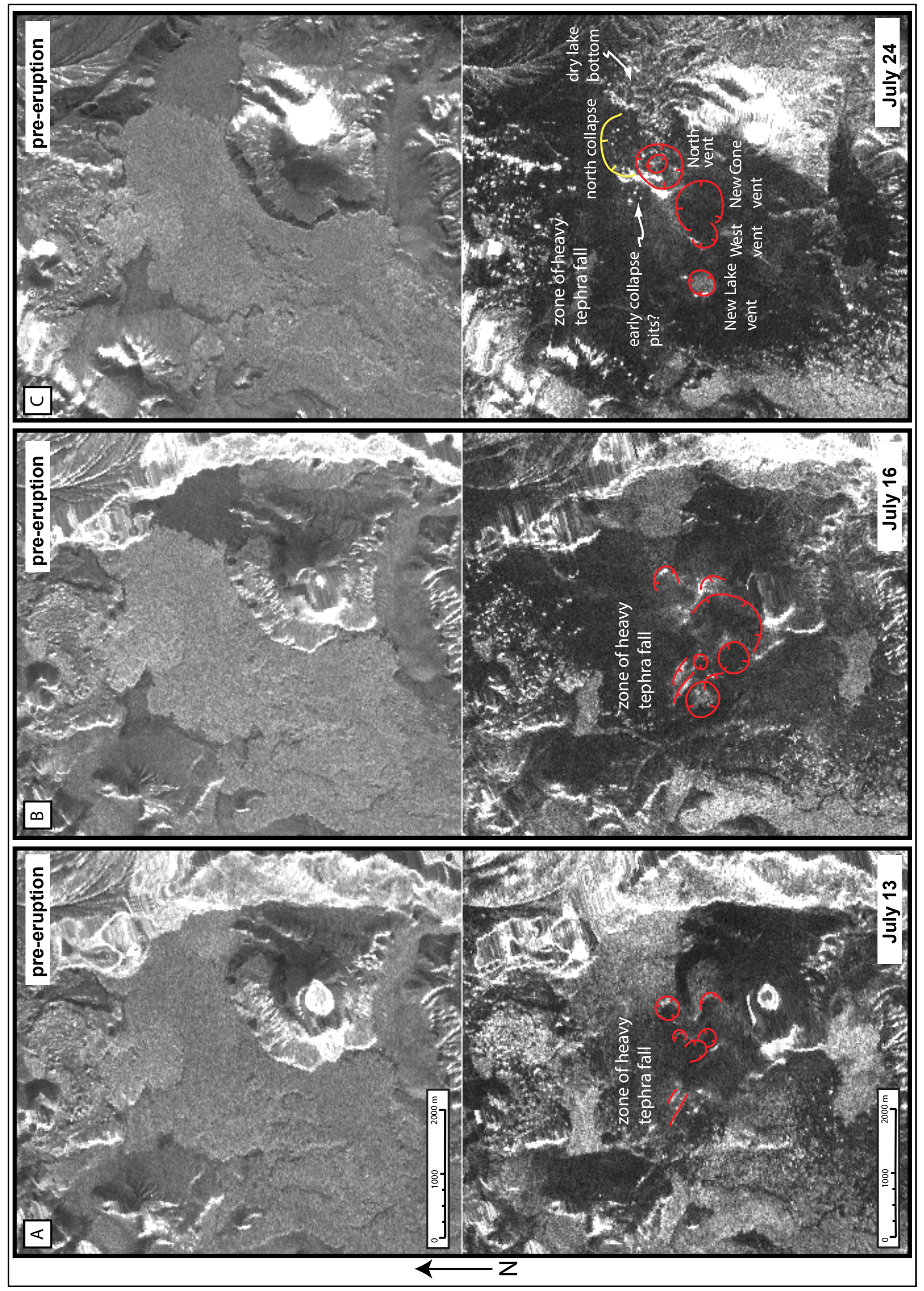

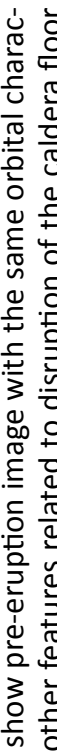

능

离

응 융

突

늠.

ஸे vi

t5

on

安

它

焉

$m$ 흠

文经

$\varepsilon \%$

응 해용

品

흥

흥 웡

음

ह

흥 잉

4

음

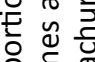

$\therefore$.

पू

列

응ㅎํ.

o

눙 $\frac{\pi}{2}$

ธ이

品 $\frac{1}{00}$

宅응

당

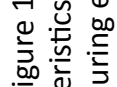




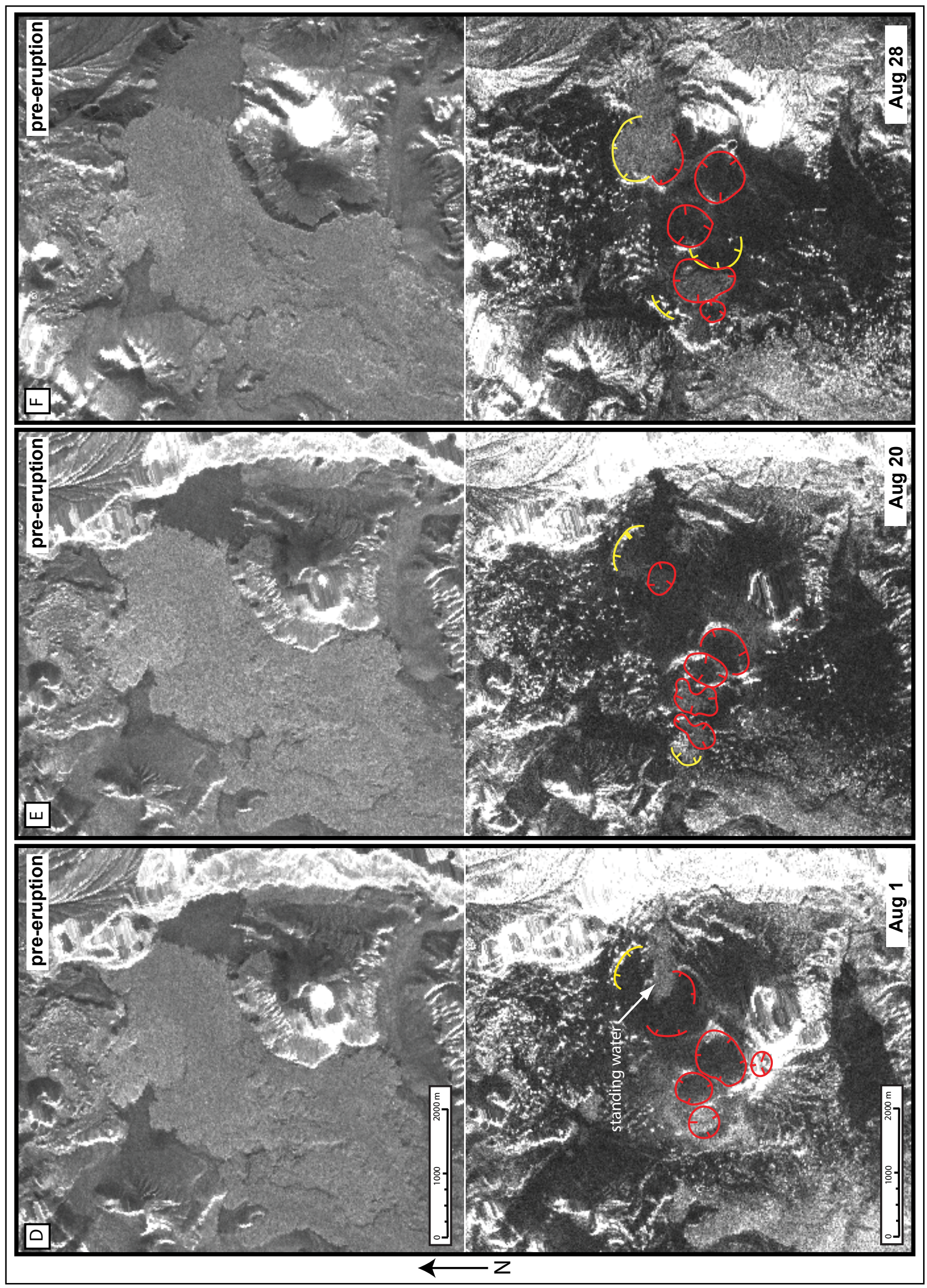


enlargement of the initial vents, between July 13 and 16 . The reflective signal of pre-eruption blocky lava flows west and north of Cone D is further subdued by this time. The Cone D lake remains visible; variable reflectivity along the western shoreline may be explained by infilling with debris. Much of the eastern caldera has been blanketed by tephra and areas on the northeast and south flanks have also accumulated tephra visible in SAR imagery (fig. 15).

\subsubsection{Draining of North Cone D lake}

By July 24, primary vent features that persisted to the end of the eruption were well established (fig. 14C). In the most westerly position, we identify a new lake vent, a circular maar-like feature that formed in the middle of the 1958 lava field. This vent may have contained water on July 24. Near Cone D, closely spaced circular features mark the sites of West vent and Ahmanilix. To the north of Cone D, a circular depression encloses North vent, whose southern margin lies against the north base of Cone D. Just to the north of this feature, an arcuate scarp (north collapse, fig. 14C) cuts deeply into the 1958 lava flow and forms the margin of a large basin with a blocky, reflective floor. In addition, scattered isolated reflectors to the west of the arcuate scarp are seen for the first time. We discuss the significance of the arcuate scarp and isolated reflectors in section 4.3.4.
The character of the Cone D lake region has changed markedly in the July 24 SAR image (fig. 14C). Reflectivity of the lake basin is high and variable, indicating significant surface roughness. We interpret curvilinear reflective features as dry gullies on the lake bottom as documented by AVO staff in late July. The exposed lake floor radar texture is continuous to the west, merging into north vent, suggesting that much of the lake drained into this vent and was at least partially consumed in the eruptive process. Field evidence does not support an alternative explanation of rapid draining of Cone D lake water down Crater Creek. A 20-hour spike in seismicity from about 1800 UTC July 19 through about 1400 UTC July 20, when seismometers recorded the most energetic, sustained seismicity following the July 12 opening sequence, likely marks the consumption of lake water by the actively erupting vent. We suggest this spike recorded continuous explosive interaction of lake water as it drained into North vent. The timing of lake draining is also supported by satellite imagery showing a dry lakebed by July 21 (UTC).

Between July 24 and August 1, North vent widened (by explosive reaming, collapse, or both), consuming some of the Cone D edifice (fig. 14D). On August 2, AVO field crews reported standing water in the dramatically altered north Cone D lake basin; this is visible in SAR imagery as a region of increasingly homogeneous reflectivity north of Cone D.

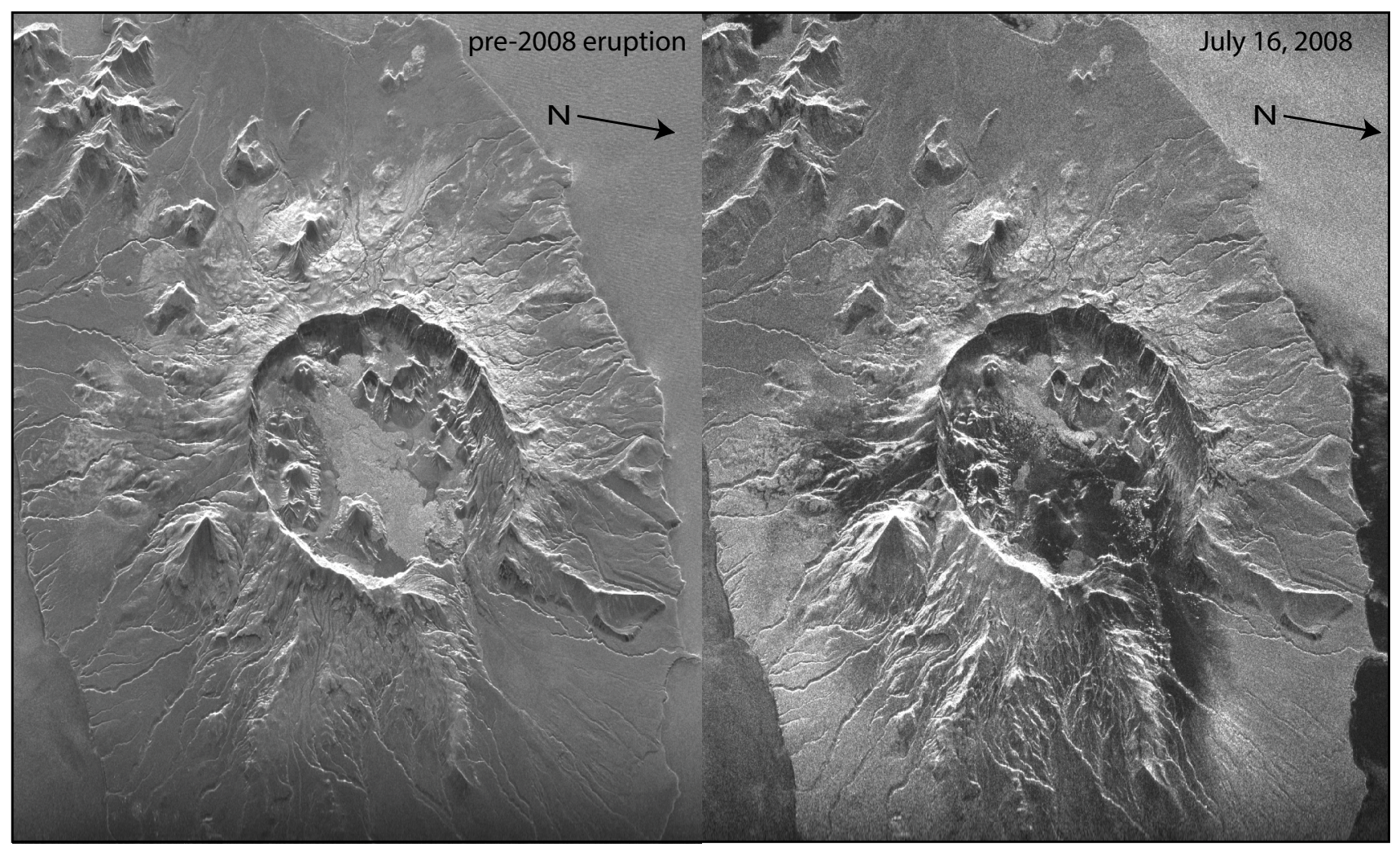

Figure 15. SAR scenes of the northeast portion of Umnak Island showing all of Okmok Caldera. Pre-eruption view at left shows rough-surfaced 1997 and 1958 lava flow fields inside the caldera. A scene from July 16 (right), four days into the eruption, shows the broad area of the caldera floor disrupted by explosive reaming; dark areas indicate significant tephra accumulation. SAR images were acquired by the C-band ERS-2 satellite during ascending passes when the satellite traveled from south to north and looked east. Pre-eruption scene is produced by averaging multi-temporal SAR images to reduce speckle noise. 
By this time, both Ahmanilix and West vent were distinct crater forms with prominent raised rims; satellite imagery shows multiple smaller craters inside the larger West vent. Murky photographs of the vent area on August 1 by Lonnie Kennedy also show collars of dark tephra creating positive relief around distinct point sources of water vapor emission (fig. 16). The August 1 SAR image also shows that New Lake vent west of Cone D had grown. The area and number of isolated reflective features tens of meters across and north of the vent region atop the 1958 lava field increased and extended to the southwest between July 24 and August 1.

On August 2, with AVO observers on site, ash production abruptly increased in intensity, resulting in darker, more ash-rich plumes from multiple sources on the caldera floor (figs. 10A and 11). Two spikes in seismicity (about 90 and 45 minutes in duration) were recorded during this time. Video and still photographs confirm increased ash output, which continued into August 3 (fig. 10B). Based on satellite images, some of the increased intensity of ash production of August 2-3 is likely related to explosive enlargement of New Lake vent. Observations of migrating plume sources on August 2 and 3 are consistent with non-steady-state activity from multiple vents during this time. The persistence of a lighter-colored plume adjacent to, and at times mixed with, a dark, ash-rich plume indicates continued significant involvement of water.

\subsubsection{Localization of activity at the new cone, Ah- manilix}

No SAR imagery is available between August 3 and August 20, but a USGS crew in the caldera on August 13 took still and video images of the waning stages of eruption (fig. 10C). By this time, North Cone D lake had grown significantly. Water filled North vent and portions of the basin south of the arcuate escarpment through the 1958 lava flow. Eruptive activity continued only from Ahmanilix and consisted of closely spaced pulses of dark ash roiling 300-400 m above the rim. The ash column was surrounded by a collar of water vapor, and dark patches on the flanks of the new cone marked locations of ballistic impact craters. Additional collapse of the ground surface was noted to the west of the New Lake vent (fig. 14E), producing an east-facing, terraced escarpment cutting the 1997 lava flow. This feature is similar in form to the arcuate collapse feature cutting the 1958 flow north of North vent (fig. 14C). We note that both scarps cut blocky 'a'a lava flows and suggest that these ground failures occurred where water-saturated alluvial substrate collapsed into void space created by groundwater and sediment withdrawal (see section 4.3.4). When the area was visited in September 2008, water, likely from Cone J lake (fig. 12), was issuing from springs at the base of the escarpment into the basin that became West Cone D lake.

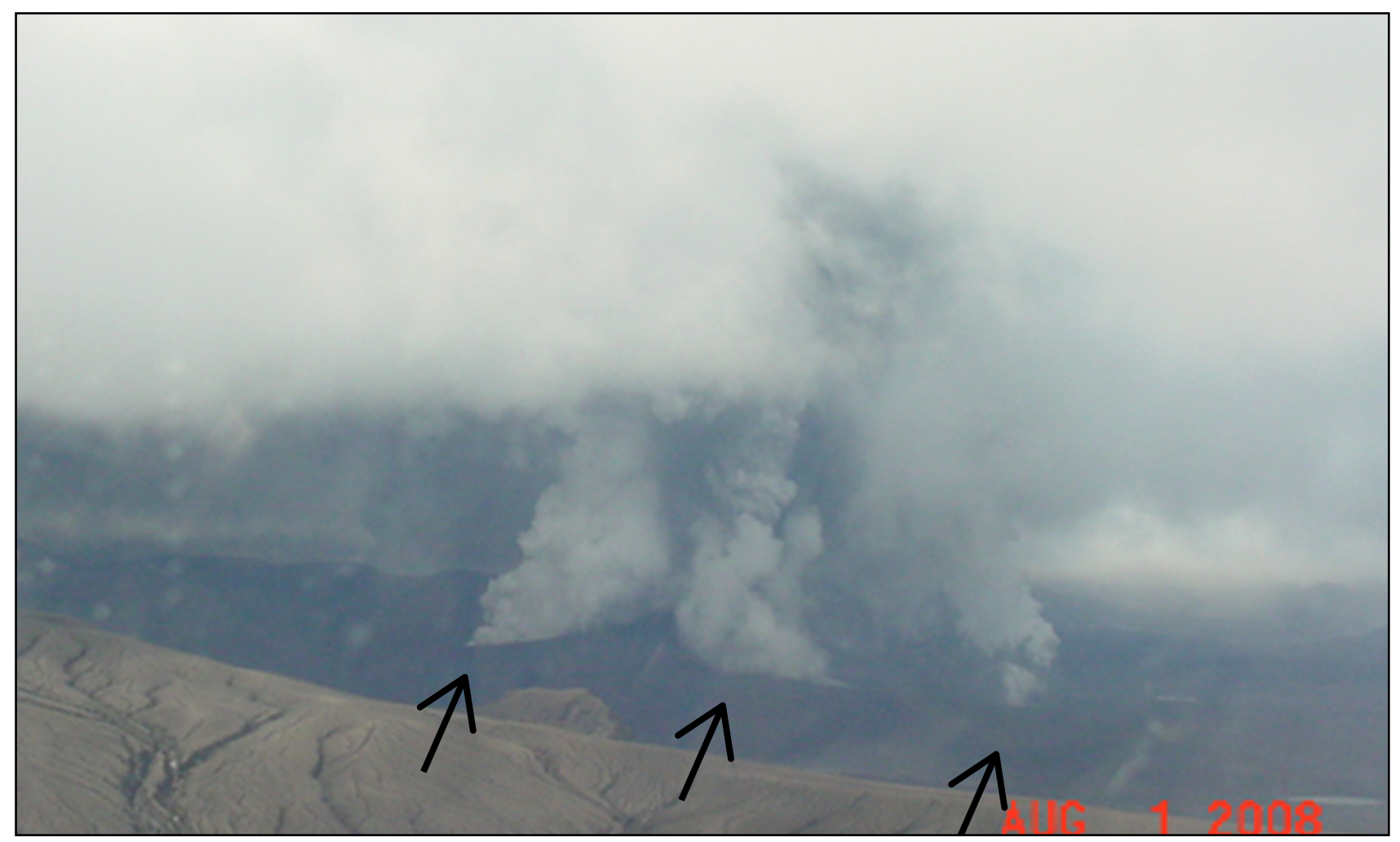

Figure 16. Oblique aerial view of active vents in Okmok Caldera on August 1, 2008 (arrows). View is southward over the north rim of the caldera. Sources of water vapor and some ash are, likely, from left to right, the new cone Ahmanilix, West vent, and West Cone D lake vent. Cone D is obscured by the ash and vapor cloud. Photograph by L. Kennedy, used with permission. AVO image database URL: http://avo.alaska.edu/images/image.php?id=15667 


\subsection{New volcanic landforms inside the caldera}

In contrast to the largely effusive 1997 eruption, the 2008 eruption caused profound changes to the intracaldera landscape at Okmok. Weeks of phreatomagmatic explosions produced significant volumes of largely fine-grained tephra fall that thickly blanketed the eastern caldera floor, rim, and portions of the volcano's flanks, and formed a new tephra cone in the caldera. Additionally, explosive activity disrupted a broad region of the caldera floor, creating new craters by explosion and collapse. Several closely spaced new craters intersected the shallow groundwater system and formed a new lake west of Cone D (West Cone D lake). In addition to these dramatic eruption-induced changes, unconsolidated 2008 tephra deposits were vulnerable to rapid remobilization by strong Aleutian rains; rates of erosion observed in the first few years after the eruption are significant. In September 2008 , only weeks after the end of the eruption, new features were already modified (figs. 17-18). By August 2010, accumulation of runoff, lake level rise, and bank retreat had enlarged areas covered by both North Cone D lake and West Cone D lake, obscuring many details of vent morphology. West and North vents were losing distinctive sharp rims and walls. Many of the smaller pits to the north of Ahmanilix were greatly subdued and partially or completely filled with sediment or standing water (fig. 17).

\subsubsection{The 2008 tephra cone, Ahmanilix}

Ahmanilix is a $300-\mathrm{m}$-tall cone marking the primary 2008 vent. By the eruption's end, steeply sloping tephra deposits of Ahmanilix enclosed a circular crater 750-800 m in diameter and $\sim 150 \mathrm{~m}$ deep. The highest point on the south rim of the new tephra cone in September 2008 was $\sim 700 \mathrm{~m}$ ASL_about $335 \mathrm{~m}$ above the caldera floor and $220 \mathrm{~m}$ higher than the Cone D lava bench. Immediately after the eruption, tephra from the rim and inner crater walls began washing and slumping onto the crater floor, eventually creating a broader, more gently sloping basin hosting a small, shallow pond (fig. 18B).

By 2010, erosional gullies, some more than $10 \mathrm{~m}$ deep, had formed high on the flanks of Ahmanilix (fig. 19). These steep-walled gullies exposed bedded tephra deposits consisting primarily of ash and lapilli. Proximal deposits are matrix supported, weakly consolidated, and able to support vertical exposures of several meters. Where exposed on the south side of Ahmanilix, the base of the 2008 section sits atop pre-eruption volcaniclastic sediments that overlie Cone D bench lavas. The 2008 basal unit consists of up to several meters of a massive, indurated, poorly sorted, coarse ash, lapilli, and block breccia containing both juvenile and lithic clasts up to $50 \mathrm{~cm}$ in size. No signs of palagonitization were evident in 2008 deposits. Northern Arizona University graduate student Joel Unema and advisor Michael Ort describe this deposit in greater detail in a manuscript in preparation.

On the rim of Ahmanilix, blocks and bombs ranging in size from several tens of centimeters to $1 \mathrm{~m}$ in diameter are scattered on the surface and visible in uppermost tephra beds below the rim (fig. 20). Blocks are mostly dense lava fragments likely mined from lavas of Cone D. Juvenile bombs up to $20 \mathrm{~cm}$ across, found along the rim of Ahmanilix, are similar to juvenile bombs collected in basal units of the 2008 section. One juvenile bomb from the rim is dark grey with a reddish purple interior. It is dense, poorly vesicular, and contains sparse plagioclase, pyroxene, and olivine phenocrysts.

Ballistic fragments ejected from Ahmanilix in 2008 were identified as far as $4 \mathrm{~km}$ from the primary vent in the vicinity of the Gates (station 10JFLOK018, fig. 6). At this location, the maximum juvenile bomb at the base of the section was $18 \mathrm{~cm}$. Maximum clast size quickly drops off to the northeast to $3-5 \mathrm{~cm}$ at site 08 JFLOK016. Obvious ballistics from the eruption's energetic opening phase remained in the caldera, reaching approximately $4 \mathrm{~km}$ from Ahmanilix. Overall, ballistics were concentrated northeast of the vent. Late-stage ballistics fell largely in the immediate vicinity of Ahmanilix (fig. 21), marked by small impact craters visible from the air during the eruption's waning stages and immediately after eruption cessation.

We estimate the volume of Ahmanilix by comparing a pre-eruption DEM derived from AirSAR and Shuttle Radar Topography Mission (SRTM) data (Schaefer, 2005) to a DEM created post-eruption in 2010 (Schaefer and others, 2011). The bulk volume change of the $2.4 \mathrm{~km}^{2}$ area that defines the new cone is approximately $0.22 \mathrm{~km}^{3}$, more than half the total 2008 eruptive volume $\left(0.35 \mathrm{~km}^{3}\right.$; see section 4.4$)$.

\subsubsection{West vent and adjacent craters}

Immediately west of and adjacent to Ahmanilix is another crater formed during the eruption, West vent. When first seen in 2008, West vent was an asymmetric crater with a diameter of about $500 \mathrm{~m}$, cutting into the northwestern flank of Ahmanilix. A low collar of tephra enclosed the crater on the west and separated West vent from another circular crater, New Lake vent, indicating that its asymmetrical shape resulted from formation on the steep flanks of Ahmanilix. New Lake vent contained standing water one week into the eruption; post-eruption, it is filled by what is now called West Cone D lake (fig. 22).

\subsubsection{North vent}

North vent began forming early in the eruption and gradually enlarged to become an 800-m-diameter circular basin immediately north of Cone D and at the northeast base of Ahmanilix. By July 21, water from the former Cone D lake had drained and its basin had merged with North vent. At the same time, collapse of the 1958 lava flow north of North vent produced an arcuate escarpment with downdropped blocks of lava tilted in the direction of the vent. When visited in 2008, North vent was recognized only by a circular embayment of the newly expanded North Cone D lake (fig. 23). After the eruption, without the radar record of a crater developing in that location, it would be difficult, if not impossible, to identify North vent as an eruptive feature of any significance. 

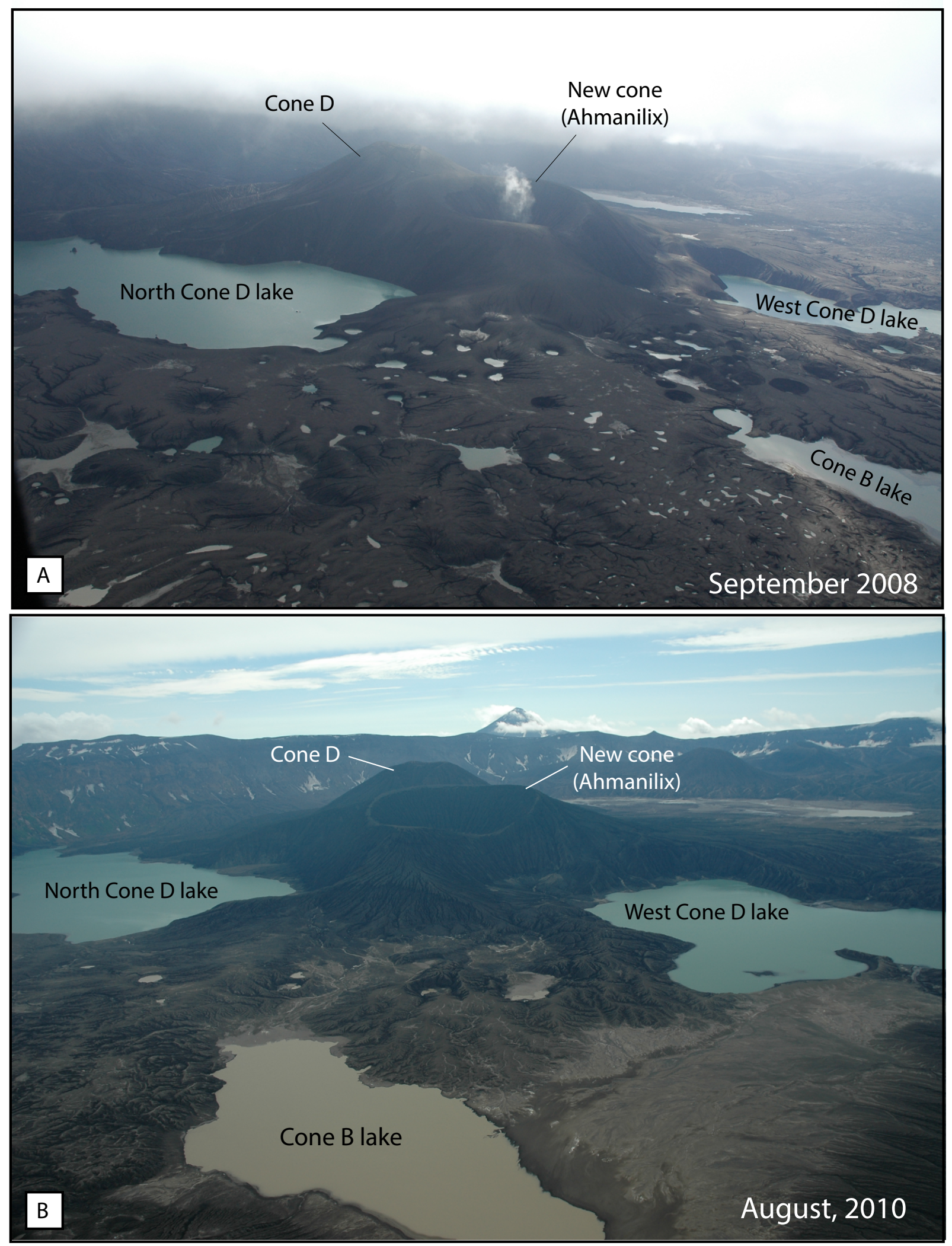

Figure 17. Oblique aerial photographs of North Cone D lake, the new tephra cone Ahmanilix, and West Cone D lake. A. Photograph from September 2008, looking south. Water-filled, mostly circular collapse pits are visible in the region between the lakes in center of photo. B. Photograph from August 2010, looking southeast, showing highly modified field of collapse craters. By this time, the flanks of Ahmanilix were deeply rilled by surface runoff. The steep flanks of Ahmanilix also sloughed debris into both North Cone D lake and West Cone D lake. The muddy Cone B lake appears enlarged compared to 2008. Photographs by J. Larsen (UAFGI). 

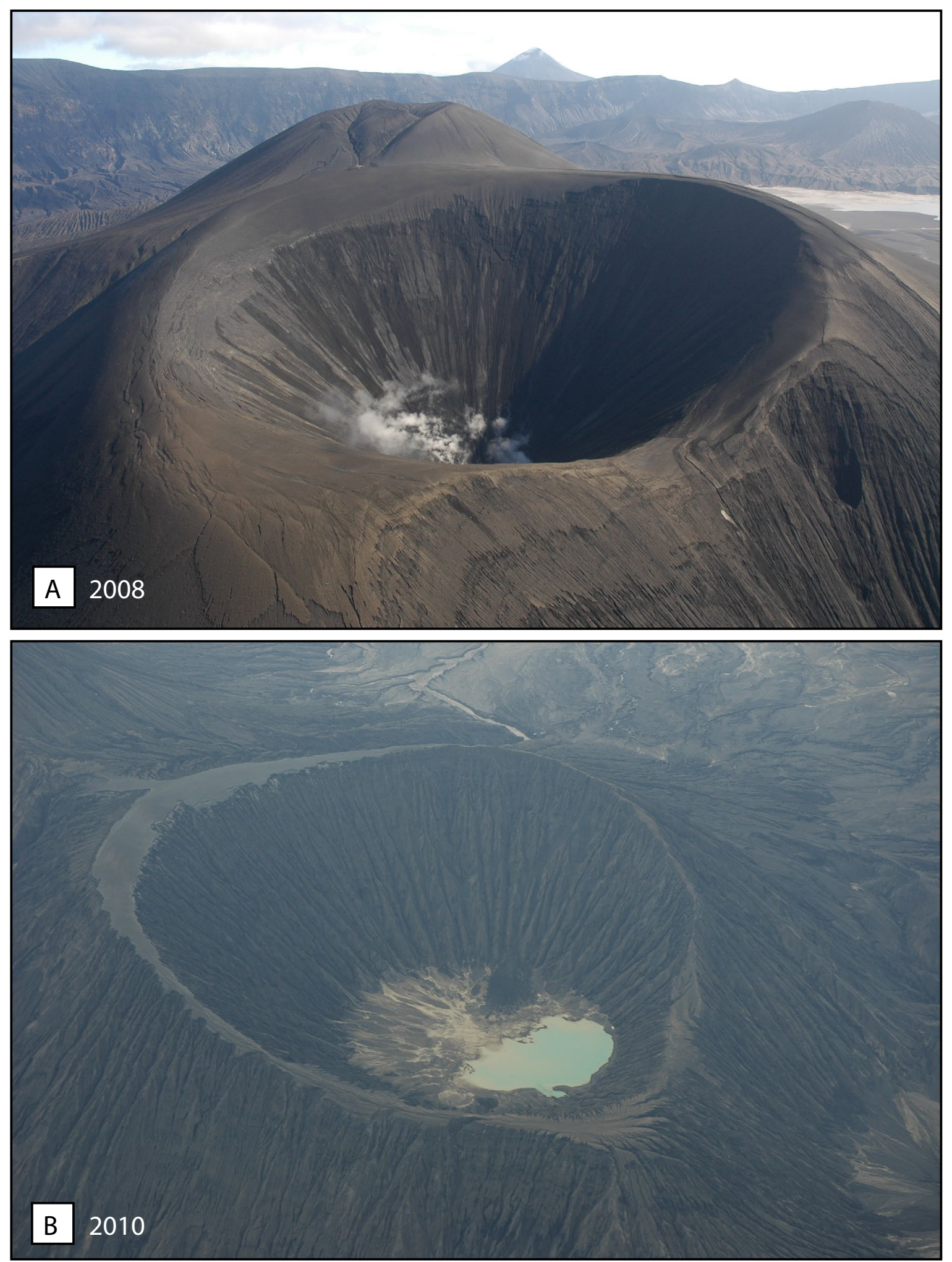

Figure 18. Oblique aerial photographs of the 2008 primary tephra cone, Ahmanilix. The diameter of the summit crater is 750 to $800 \mathrm{~m}$; the inner crater was about $150 \mathrm{~m}$ deep several weeks after the eruption. A. Photograph (southeast at top) taken September 15, 2008, showing the relatively pristine inner crater, still warm and steaming. The summit of Cone D is just behind the rim. B. Photograph (south at top) during summer 2010, showing significant erosion of the cone and infilling of the crater by sediments from the crater walls. The crater showed no obvious signs of elevated temperatures in summer 2010 and a small pool of water had collected at the bottom of the crater. Photographs by J. Larsen (UAFGI). 
Figure 19. Photographs of Ahmanilix in July and August 2010, showing deeply rilled and eroded flanks. A. Oblique aerial overview looking southeast, showing deep erosional rills. Arrow points to linear subsidence(?) escarpment about halfway down the north flank of the cone. B. Photograph of Michael Ort (Northern Arizona University) and Tina Neal (USGS) hiking down the north flank of Ahmanilix. C. Photograph showing the lower north flank of Ahmanilix, looking east, adjacent to North Cone D lake, with UAF geologist Jim Begét for scale (circle). Photographs by J. Larsen (UAFGI).
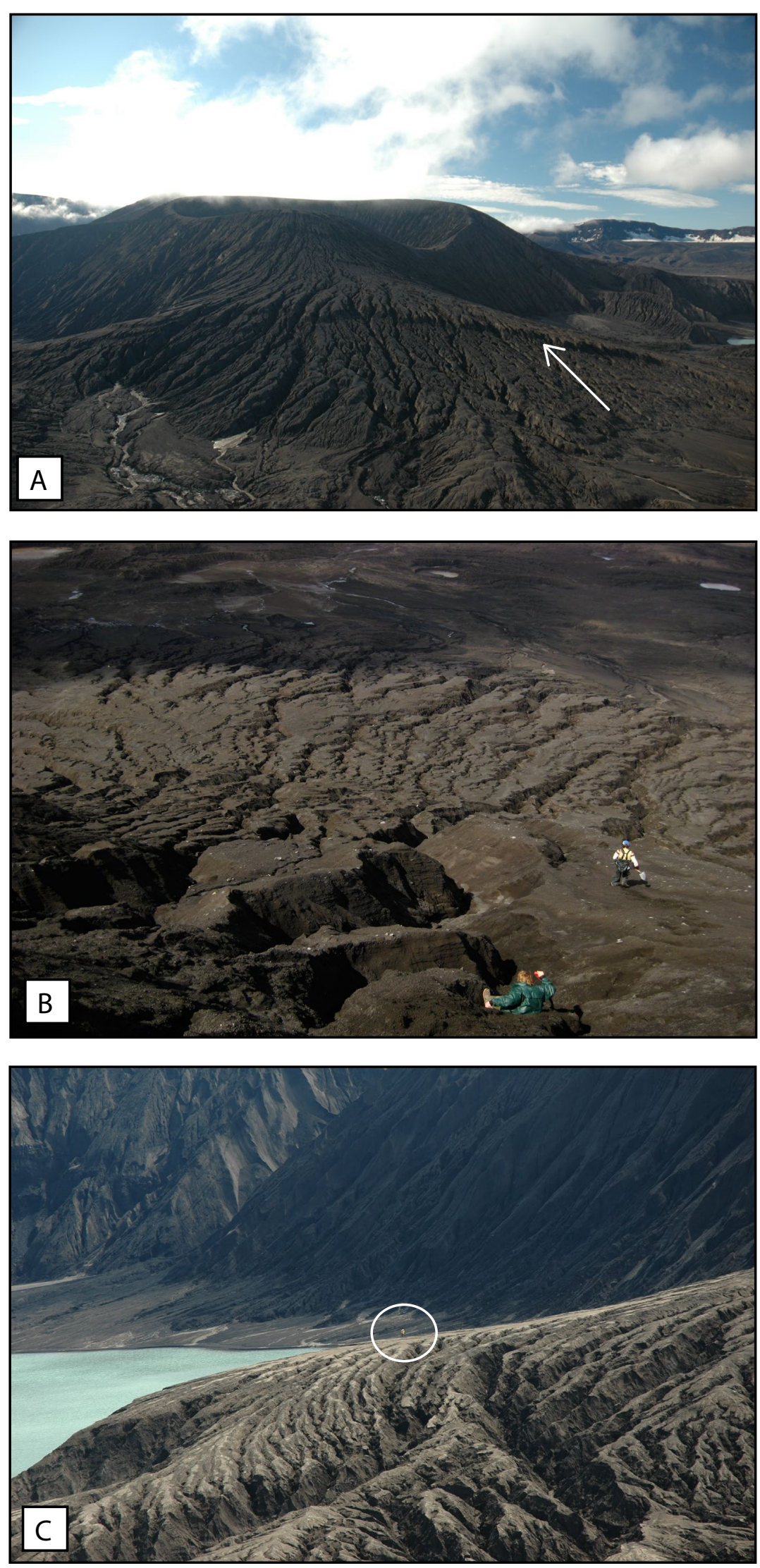

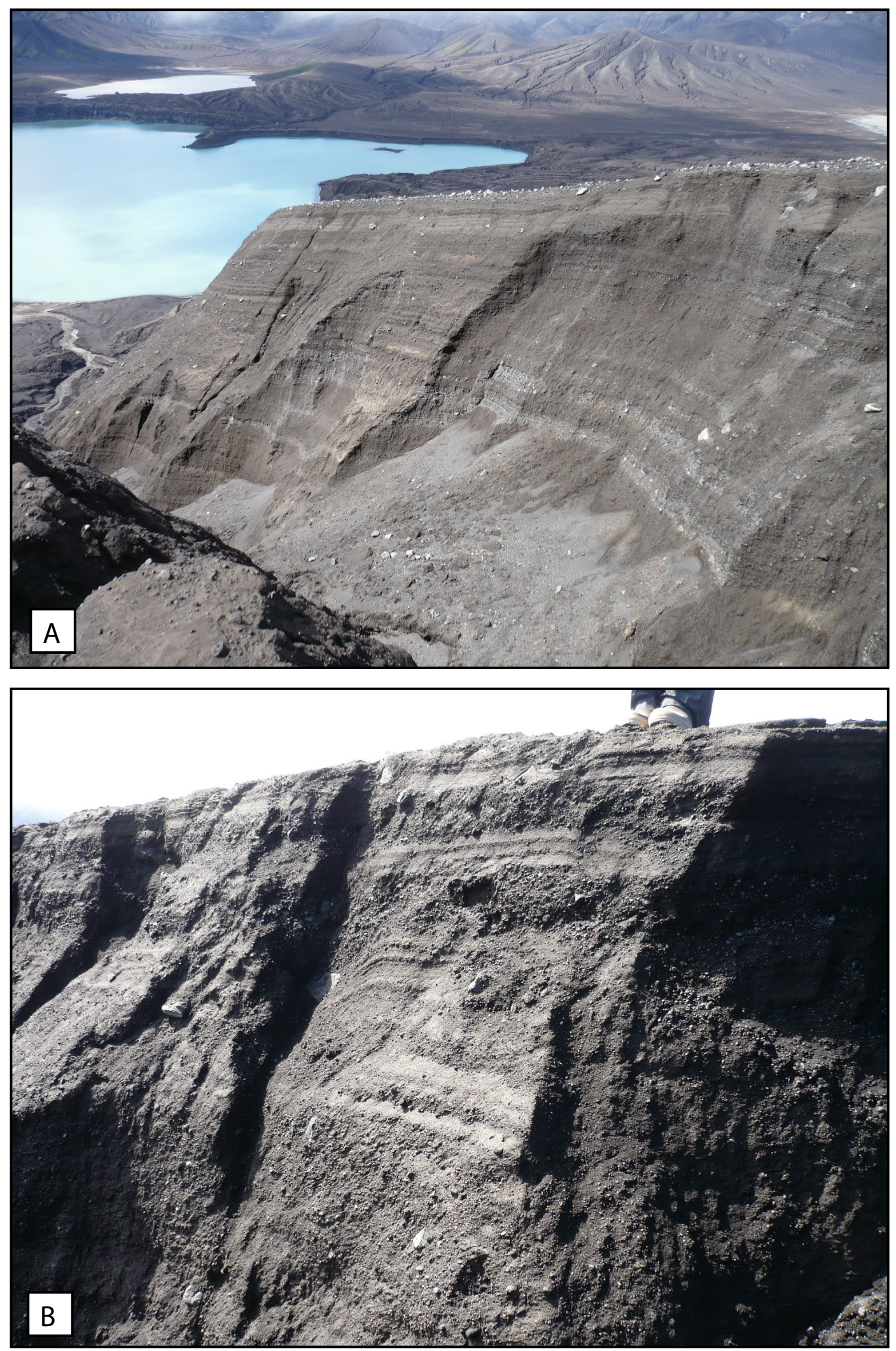

Figure 20. Photographs showing near-surface deposits of the 2008 tephra cone, Ahmanilix. A. Section on the outer flanks of the new cone, approximately $10 \mathrm{~m}$ exposed on the steep wall in this photograph. Deposits consisted of ash- and lapilli-sized material with larger lithic ballistic blocks and juvenile bombs scattered on the surface and within individual layers. B. Closer view of the deposits forming the new tephra cone rim. Geologist's boots at the top of the section for scale. Photographs by J. Larsen (UAFGI). 


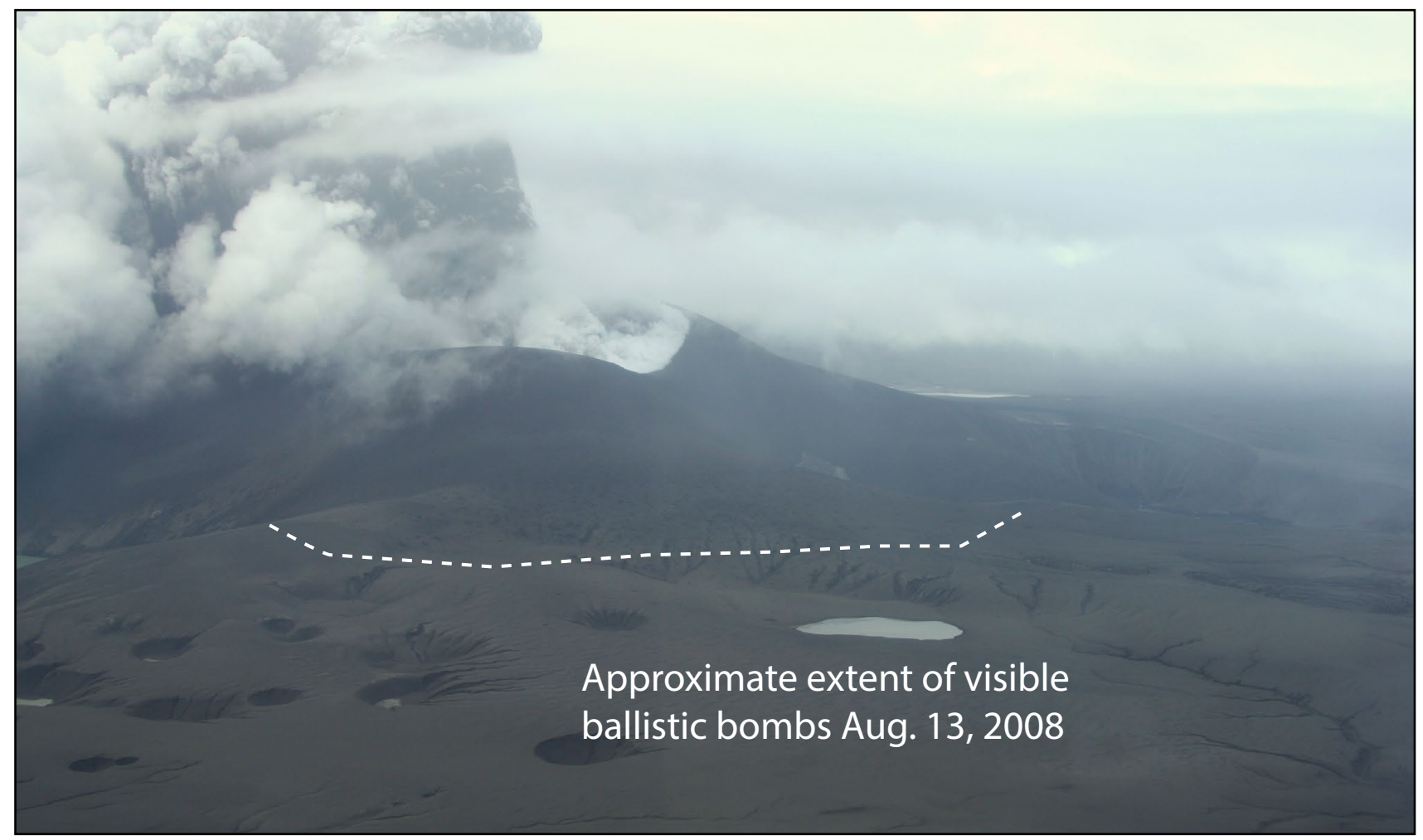

Figure 21. Oblique aerial photograph taken on August 13, 2008, showing the approximate extent of noticeable ballistic fallout around the new tephra cone. View is to the south. Water-filled circular craters in foreground are collapse features unrelated to ballistic fallout. Photograph by Chad Hults (USGS).

\subsubsection{Collapse pits and amphitheaters}

Localized collapse and subsidence of the caldera floor were important syn- and post-eruption processes that led to significant—but ephemeral—modification of the intracaldera topography.

Over the course of the eruption, dozens of steep-walled, circular pits formed on the caldera floor north of the active vents (fig. 24). They were first noted on August 13 during a USGS helicopter flight into the caldera over the region north of the erupting cone. When examined more closely in September 2008, most pits had well-defined edges but lacked raised rims; rapid incision by surface water flow was already producing networks of drainage channels cutting into the pit rims. Some pit walls were near vertical and exposed tens of meters of 2008 tephra as well as the underlying 1958 and 1817 blocky 'a'a lava flows (fig. 25); other pits were conical in shape. Pits ranged in depth from about 5 to $30 \mathrm{~m}$ and in diameter from 10 to $200 \mathrm{~m}$. They were rapidly infilling with remobilized tephra even weeks after the eruption. We further discuss the relationship of the distribution and formation of the pits in section 5.2.

Based on the appearance of scattered, small, reflective features on radar images, we infer that pit development began prior to July 24 . The number and sizes of pits increased over the final weeks of eruption. By August 2009, most of the smaller pits had partially or completely filled with reworked 2008 tephra, and pit rims had become quite rounded and subdued. The area of pits defines an oblong zone that extends across a region of the caldera floor between the northeastern lobe of the new West Cone D lake and the head of Crater Creek (fig. 26). Pre-eruption, this surface consisted of relatively flat-lying 1958 and 1817 blocky lava. Photographs taken after the eruption show water draining a broad region beneath the 1958 lava flow (fig. 27), re-establishing the headwaters of the pre-eruption Crater Creek drainage.

Other collapse features of note include two arcuate escarpments cutting 1997 and 1958 lava flows at the west and north margins of the vent region (fig. 12). These scarps were prominent when first visited in September 2008, and exposed the entire 2008 tephra section as well as several tens of meters of previously flat-lying, blocky lava. Both scarps displayed tephra-mantled down-dropped blocks in front of the master scarp, indicating syneruptive formation. Water filling North Cone D lake had already covered the base of the north collapse escarpment (fig. 12). The west collapse base was a chaotic field of tephra-covered lava blocks; water flowed from the base of the scarp into the west margin of the new West Cone D lake. By 2010, rising lake levels obscured much of the exposed lava cliffs of both escarpments.

\subsection{Thermal features and measurements}

In September 2008 we collected FLIR (Forward Looking Infrared) images of significant thermal features inside Okmok 

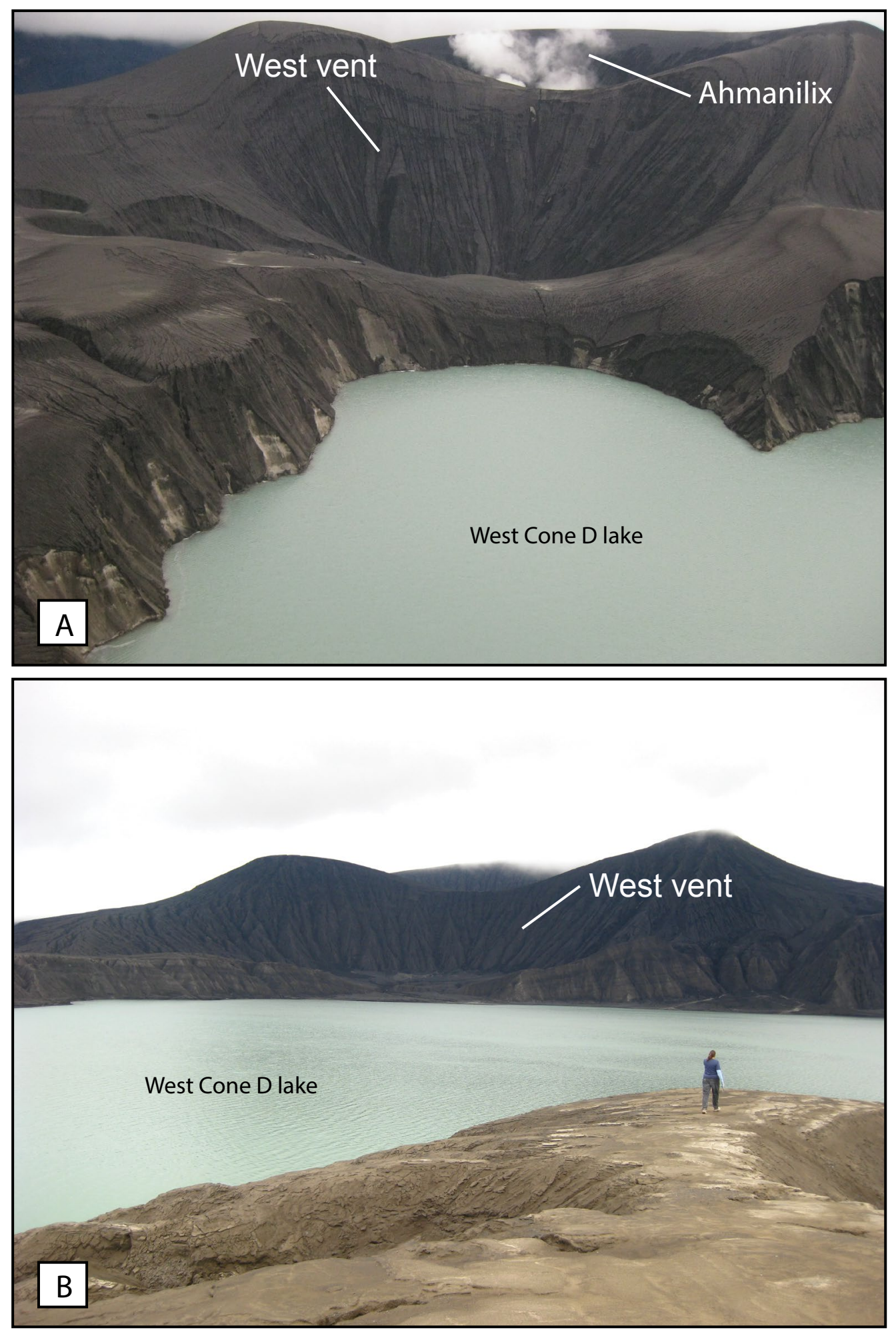

Figure 22. Comparison photographs, looking east, of West vent adjacent to the new tephra cone, Ahmanilix. A. Oblique aerial photograph taken September 2008, showing the relatively uneroded West vent crater with Ahmanilix crater steaming in the background. Note the low-relief tephra collar around the western margin of the crater. Lighter-colored material in the walls of West Cone D lake is tephra that is dry; darker overlying tephra is variably wet. B. Photograph taken during summer 2010, showing severely rilled crater walls. By this time, tephra eroded from the crater walls has almost completely filled the West vent crater with sediment. DGGS geologist Janet Schaefer shown in the foreground. Photographs by J. Larsen (UAFGI). 


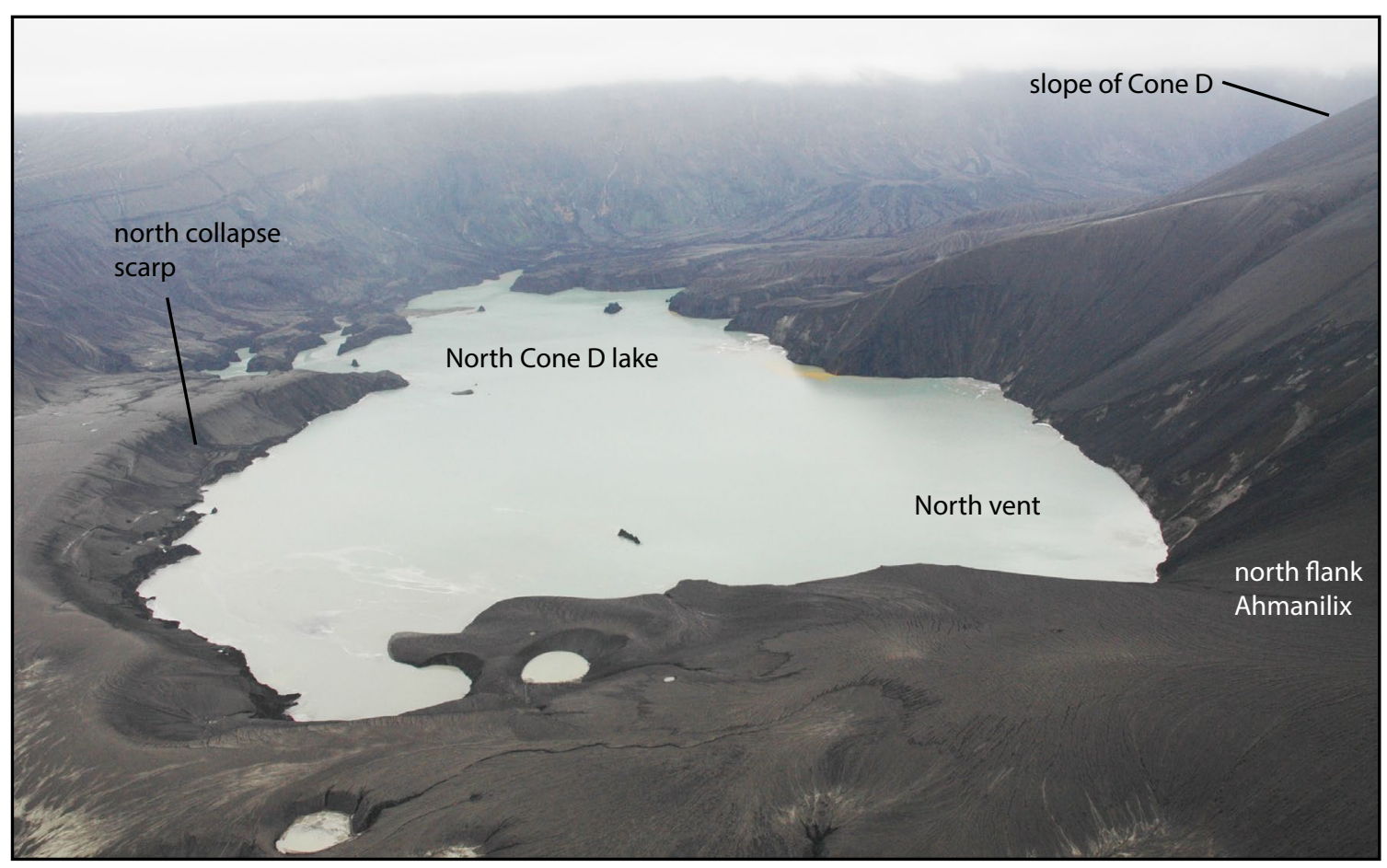

Figure 23. Oblique aerial photograph of the flank of Ahmanilix and Cone D, labeled with the approximate position of North vent, now filled with North Cone D lake water. View is to the east. North Cone D lake dimension is about $2.3 \mathrm{~km} \times 1 \mathrm{~km}$ in this image. Photograph taken September 2008 by C. Neal (USGS).

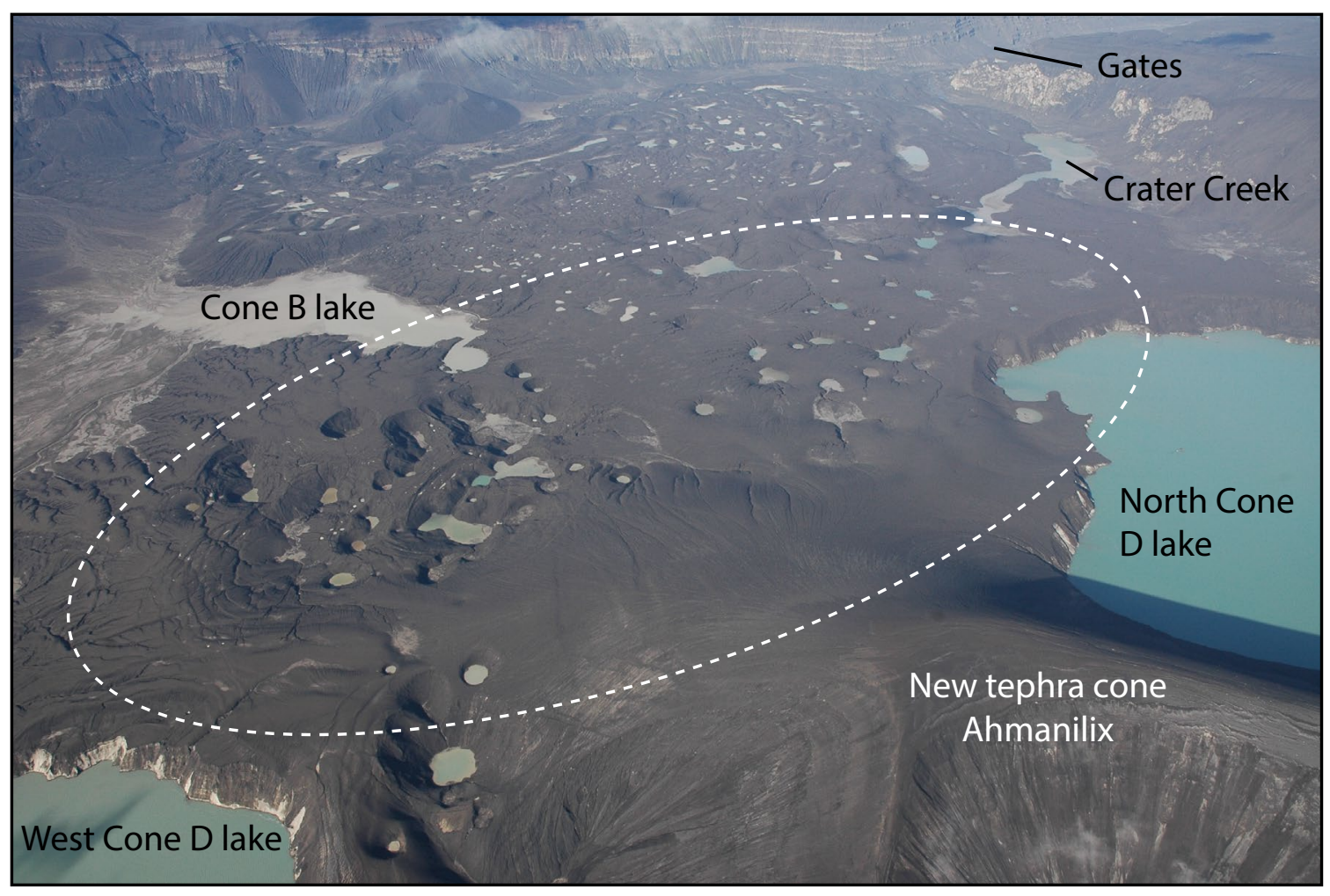

Figure 24. Oblique aerial photograph, north at top, showing approximate boundary (dashed line) of the field of collapse pits that formed during the eruption. Most features held standing water when this photograph was taken on September 15, 2008. North of the collapse pits region, scattered water-filled features lie atop the irregular surface of the Cone B lava flow and related deposits, and do not reflect collapse pits related to the 2008 eruption (see text). Photograph by C. Neal (USGS). 


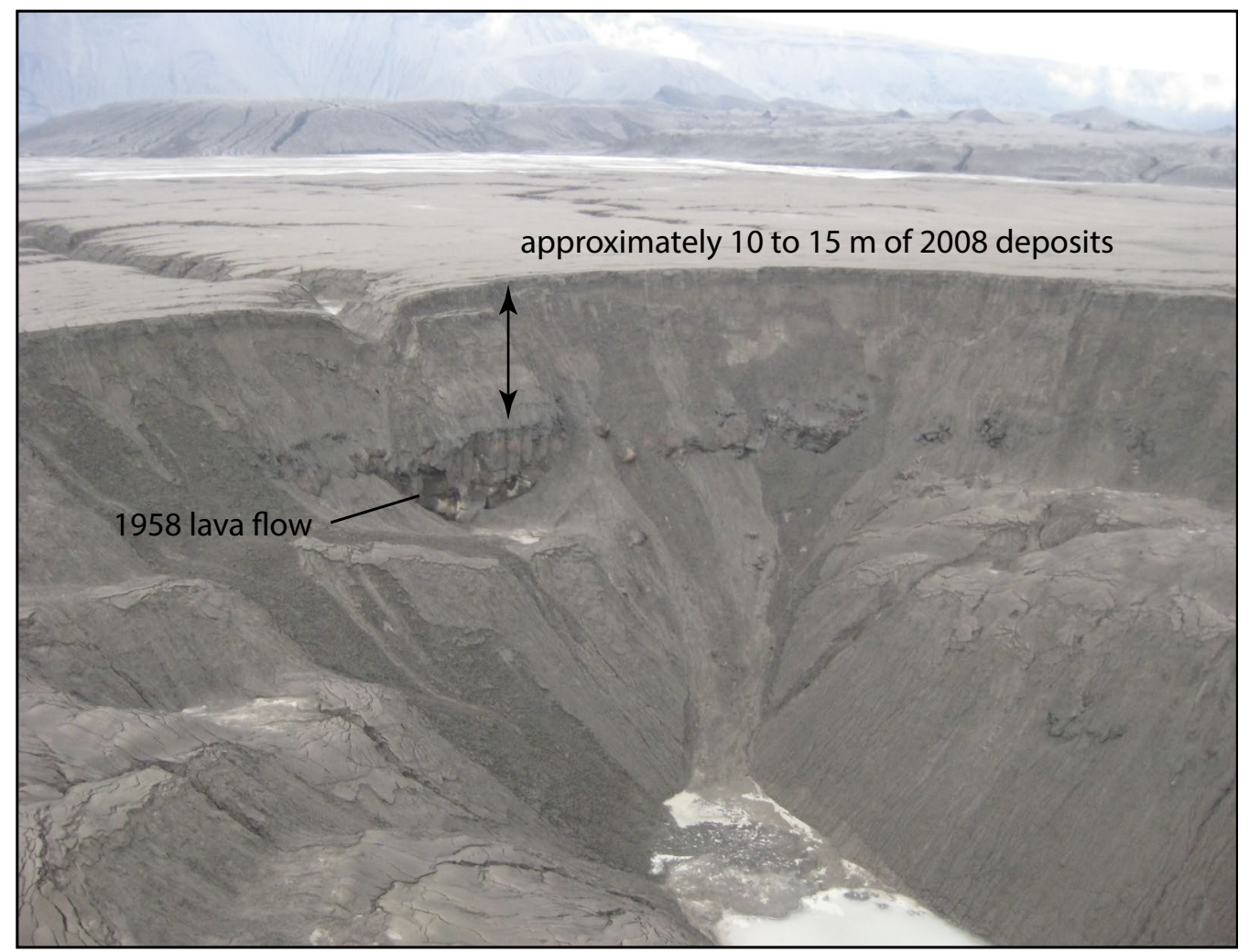

Figure 25. September 15, 2008, photograph showing the interior walls of one collapse crater formed during the 2008 eruption. Note several meters of incision into the crater rim by surface drainage. Tephra-buried, slump-block terraces in the crater are consistent with collapse during the period of tephra eruption. Lava from 1958 flow is exposed in the pit wall. Approximate scale is noted on photograph. Photograph by C. Neal (USGS).

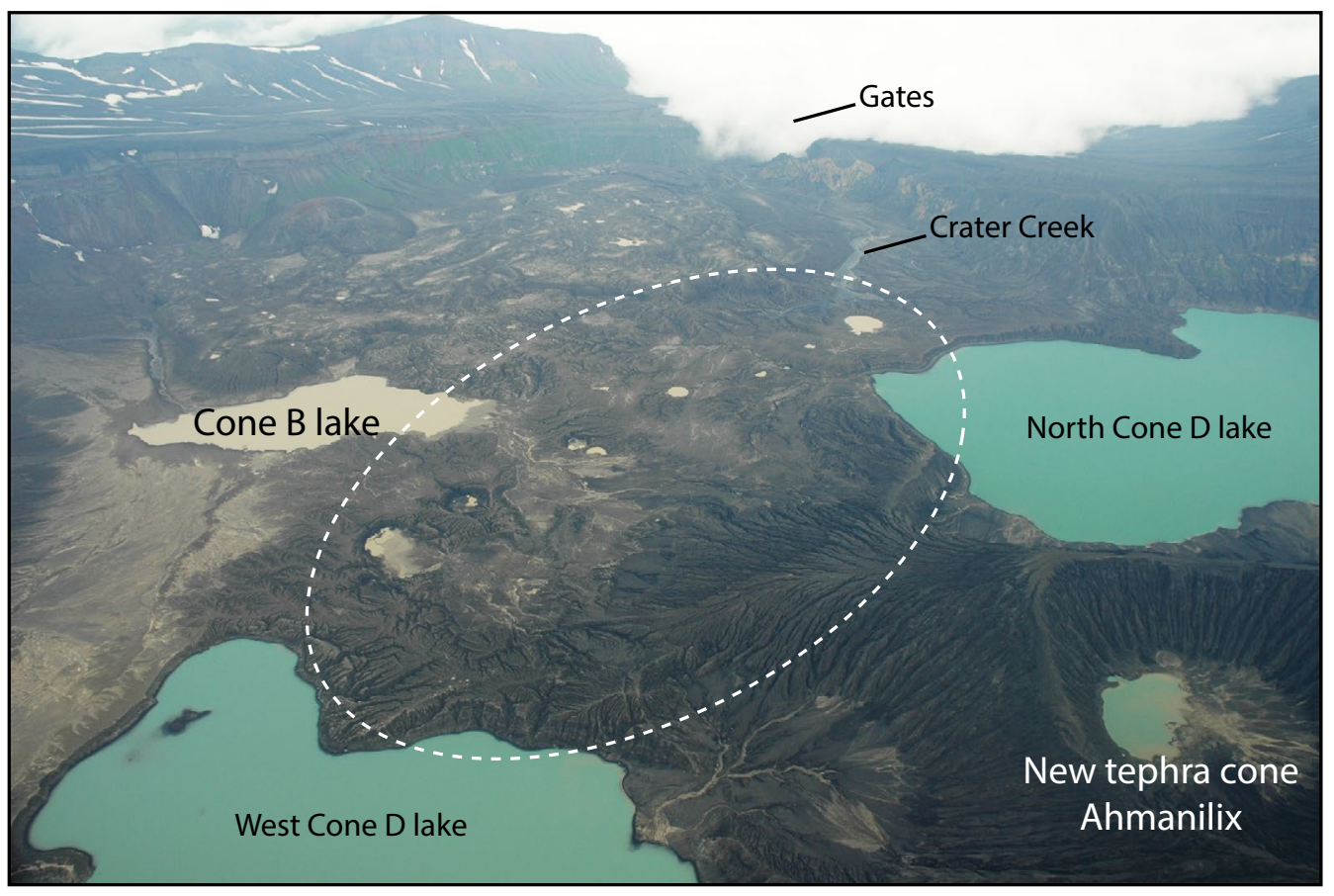

Figure 26. Oblique aerial photograph from summer 2010, showing the approximate zone of original collapse craters extending about $2.5 \mathrm{~km}$ between West Cone D lake and the headwaters of Crater Creek. Crater Creek drains the caldera through the Gates. Compare this 2010 image with figure 24 (taken in 2008) to see the impacts of two years of erosion and sedimentation. View is toward the north. Photograph by J. Larsen (UAFGI). 
Figure 27. Series of oblique aerial photographs showing the headwaters of Crater Creek, which drains the caldera through the Gates. A. Photograph from September 2008 looking north toward the Gates. Immediately after the 2008 eruption, thick deposits of wet, fine-grained tephra temporarily impounded the headwaters of Crater Creek, which contained incipient channels and standing water at that time. B. Photograph of the same area in panel $A$, taken August 2010. Two years after the eruption, the creek had re-established its channel and water flowed unimpeded to the Gates; the standing water shown in A had drained. C. This August 2010 view, looking west, shows the headwaters of Crater Creek, where water draining the western portion of the caldera (possibly including West Cone D lake) emerges from the interface between the overlying 2008 deposits and the underlying 1958 lava flow (arrows point to tephra-rock interface). Photographs by J. Larsen (UAFGI).
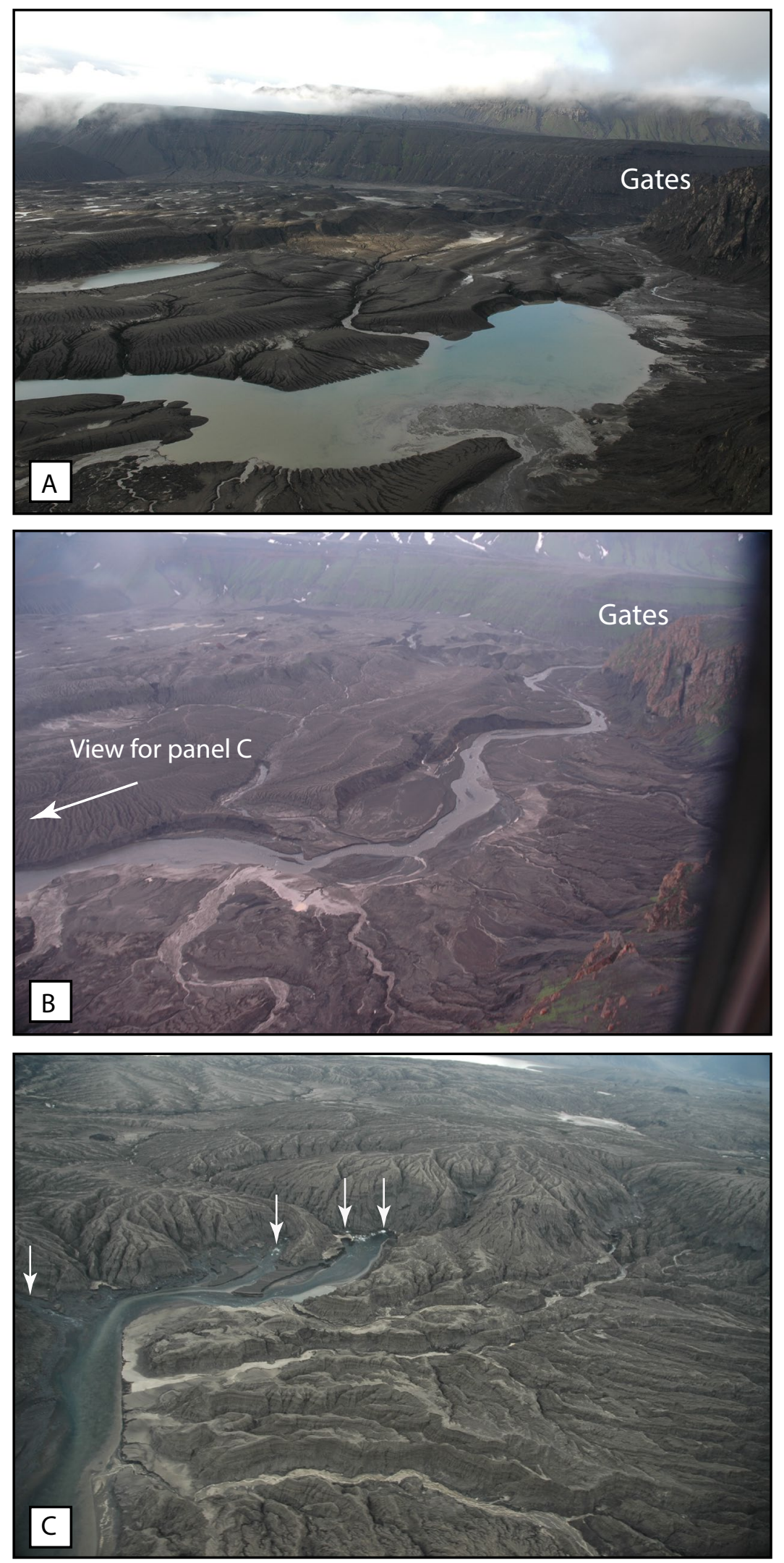
Caldera. This section presents results of these helicopter FLIR surveys and describes thermal features related to the 2008 eruption and other long-known thermal sources on and around Cones D, A, and C. Although there are no systematic, comprehensive thermal mapping studies for the area in the caldera, our results suggest that the 2008 eruption at least temporarily perturbed the hydrothermal system in the region of new vents and near Cone E, $4 \mathrm{~km}$ southwest of the 2008 primary cone (fig. 4).

In September 2008, a few weeks after the eruption's end, steam issued from a broad area on the Ahmanilix crater floor and parts of the inner crater wall (fig. 28A). FLIR images of the crater (fig. 28B) measured temperatures up to $74^{\circ} \mathrm{C}$, primarily along the southeast inner crater wall. Temperatures were several tens of degrees colder at the bottom of the crater. The crater intermittently produced discrete "puffs" of steam over periods of several to tens of minutes (fig. 29). By 2010, alluvium had greatly infilled the crater and no evidence of continued significant heat flux through the crater floor or walls was observed from the rim. No FLIR equipment was available during field visits in 2010 to quantify temperature changes.

Warm springs along the north base of Cone $\mathrm{D}$, active since at least the $1940 \mathrm{~s}$, were visibly active in the shallow North Cone D lake water prior to the 2008 eruption (Byers, 1959; Begét and others, 2005). North vent formation in 2008 excavated a portion of the Cone $\mathrm{D}$ lava bench, exposing warm springs. When visited in 2008 , these spring manifestations consisted of point sources of upwelling and discolored water along the southern margin of North Cone D lake, and steam from a steep cliff exposure of Cone $\mathrm{D}$ lavas well above the lakeshore (fig. 30A, B). FLIR images recorded temperatures up to $59^{\circ} \mathrm{C}$ for one lake upwelling area (fig. 28C) and as high as $48^{\circ} \mathrm{C}$ at the cliff exposure. By summer 2010 , visible roiling in North Cone D lake had ceased (fig. 30D) and fumaroles higher on the Cone $\mathrm{D}$ bench were also inactive.

Between 2000 and 2004, AVO scientists noted that the two summit craters of Cone A-the vent for the last historical eruption of Okmok, in 1997-remained thermally active and dry. On most days the northernmost crater produced a visible vapor plume from fumaroles on the rim and inner walls (fig. 31A). Incandescence was spotted within a 5-10-mdiameter hole at the bottom of the northern crater during the summers of 2002 and 2004 (fig. 31B). In September 2008, the northern crater hosted a small pond (fig. 31C) and FLIR images recorded a maximum temperature of $56^{\circ} \mathrm{C}$ (fig. 31D). In the summer of 2010, the north crater lake was gone, and a small, shallow pond occupied the south crater. Minor fumarolic activity was noted on the crater rim (fig. 32).

Cone $\mathrm{E}$ is a prominent, young spatter and tuff cone to the north of Cone A. The cone encloses a dramatic, steep-walled crater containing a small lake $\left(\sim 0.1 \mathrm{~km}^{2}\right.$; fig. $\left.33 \mathrm{~A}\right)$ that was bluish green in color prior to the 2008 eruption. Cone $\mathrm{E}$ lake is difficult to access safely and, to our knowledge, has never been sampled. No sign of thermal springs beneath or on the margins of the lake were previously noted. However, in early September following the 2008 eruption, the lake was strikingly greenish gray in color. The western portion of the lake hosted up to a dozen circular upwelling patches (fig. 33B). Additional areas of possible diffuse bubbling were also noted. One AVO scientist reported a 'hissing' sound; it is uncertain if this was related to the observed upwelling or the wind inside the deep crater. The roiling at the surface of the lake was, however, unprecedented in our experience and suggests new or invigorated heat input at the bottom of the lake. Surprisingly, FLIR images of the lake showed no thermal anomalies on the lake surface corresponding to the areas of upwelling (R. Wessels, oral commun., 2012). In 2010, we noted no roiling in Cone E lake, and the lake color had reverted to bluish green (fig. 33D).

Cone $\mathrm{C}$ is a $\sim 300$ - $\mathrm{m}$-tall emergent cone in the southern margin of the caldera (fig. 34). The structure is partially ringed by a lava bench, similar to that of Cone $\mathrm{D}$, which likely formed during the first thousand years after caldera formation when a large lake covered much of the caldera floor (Wolfe, 2001; Almberg, 2003). Prior to 2008, Cone $C$ hosted active fumaroles near its summit (fig. 34A); Byers (1959) reported a high temperature of $95^{\circ} \mathrm{C}$. Ken Papp (oral commun., 2001) measured temperatures between $87^{\circ}$ and $110^{\circ} \mathrm{C}$, making Cone $\mathrm{C}$ the hottest long-lived feature known within the caldera. In 2008 and 2010, Cone $\mathrm{C}$ fumaroles appeared unchanged (fig. 34B); FLIR results for Cone $\mathrm{C}$ indicated a maximum temperature of $34^{\circ} \mathrm{C}$, suggesting they may have cooled from prior years. Photographs taken (fig. 34C) in mid-January 2011 by Burke Mees showed bare, snow-free ground at the summit of Cone $\mathrm{C}$ near the active fumaroles, whereas the rest of the cones in the crater (with the exception of the Cone A rim) remained snow covered. Observations inside Okmok Caldera during the winter months are very sparse, so it is possible that the hot ground around the fumaroles noted during winter 2011 is not unusual.

\subsection{Preliminary eruption volume estimates}

Using tephra thickness measurements from September 2008, we derived preliminary eruption volume estimates. Unema and others (written commun., 2014) refine this value based on additional field measurements and more precise deposit isopachs.

The direction of ash cloud dispersal varied little throughout the eruption; between July 12 and early August, ash clouds from Okmok drifted predominantly to the east, southeast, and south. In addition to the $\sim 3 \mathrm{~cm}$ of ash fall reported at Fort Glenn ranch, a dusting of ash $(<1 \mathrm{~mm})$ was reported on July 12 and 13 in Unalaska/Dutch Harbor, $115 \mathrm{~km}$ northeast of Okmok. Eruptive activity diminished in intensity between July 20 and 25, resulting in lower plume altitudes. The eruption intensified again after July 25 and ash clouds traveled generally south to southeast until August 3, when eruptive plume heights increased temporarily to above $10 \mathrm{~km}$ and wind directions shifted, carrying the cloud to the southwest (Larsen and others, 2009). As a result, during this time period, trace to minor ash fall was reported in Nikolski 

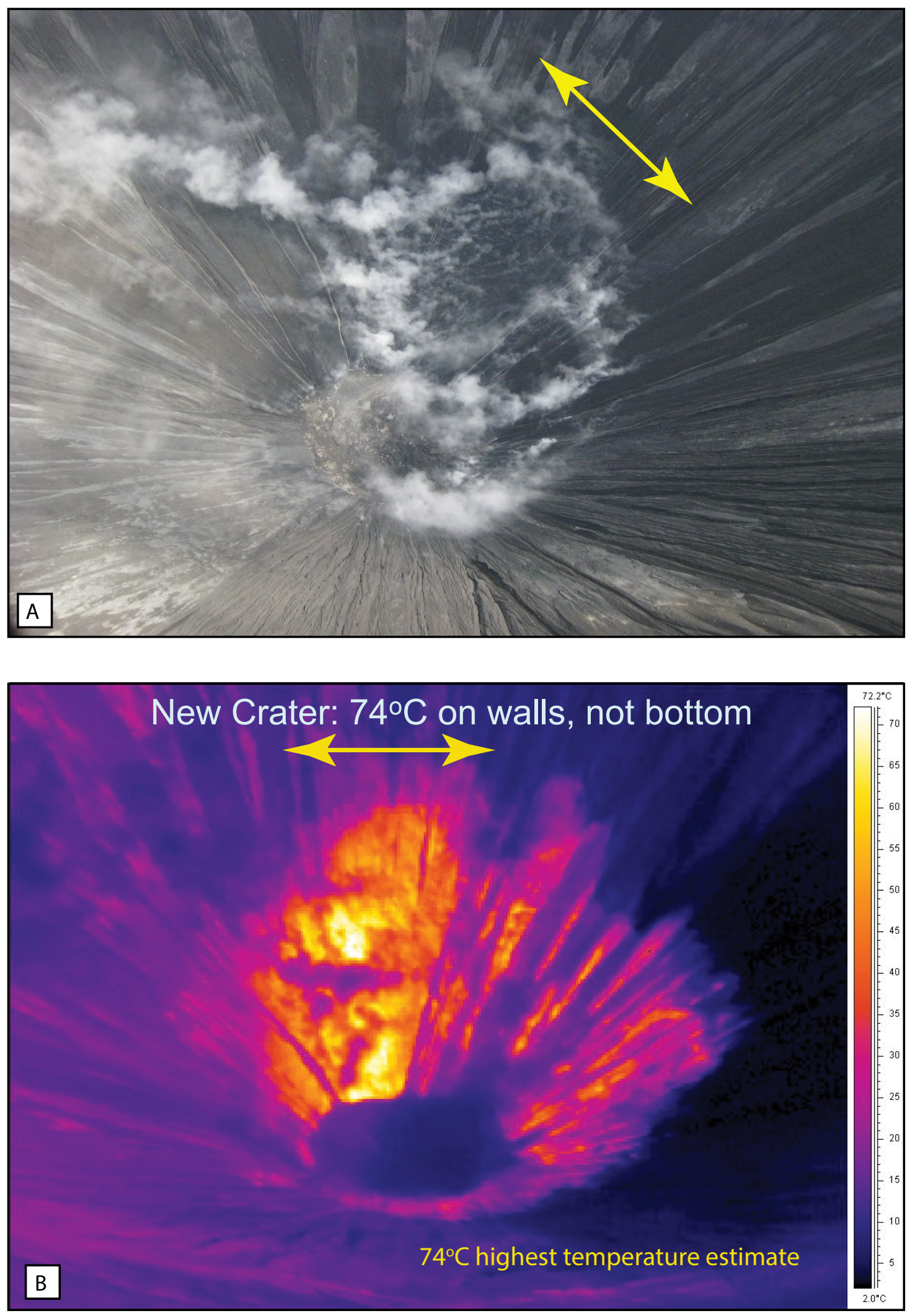

Figure 28. Photograph and FLIR image of Ahmanilix crater in 2008. A. Aerial photograph taken September 2008, looking down almost vertically inside the new crater. The yellow arrow shows the approximate hot region detected by FLIR. B. FLIR thermal camera image taken September 2008, looking inside the new crater. The hottest region is the crater wall region beneath the yellow arrow. This image shows a maximum temperature of approximately $74^{\circ} \mathrm{C}$. Photograph/FLIR image by J. Larsen (UAFGI). 


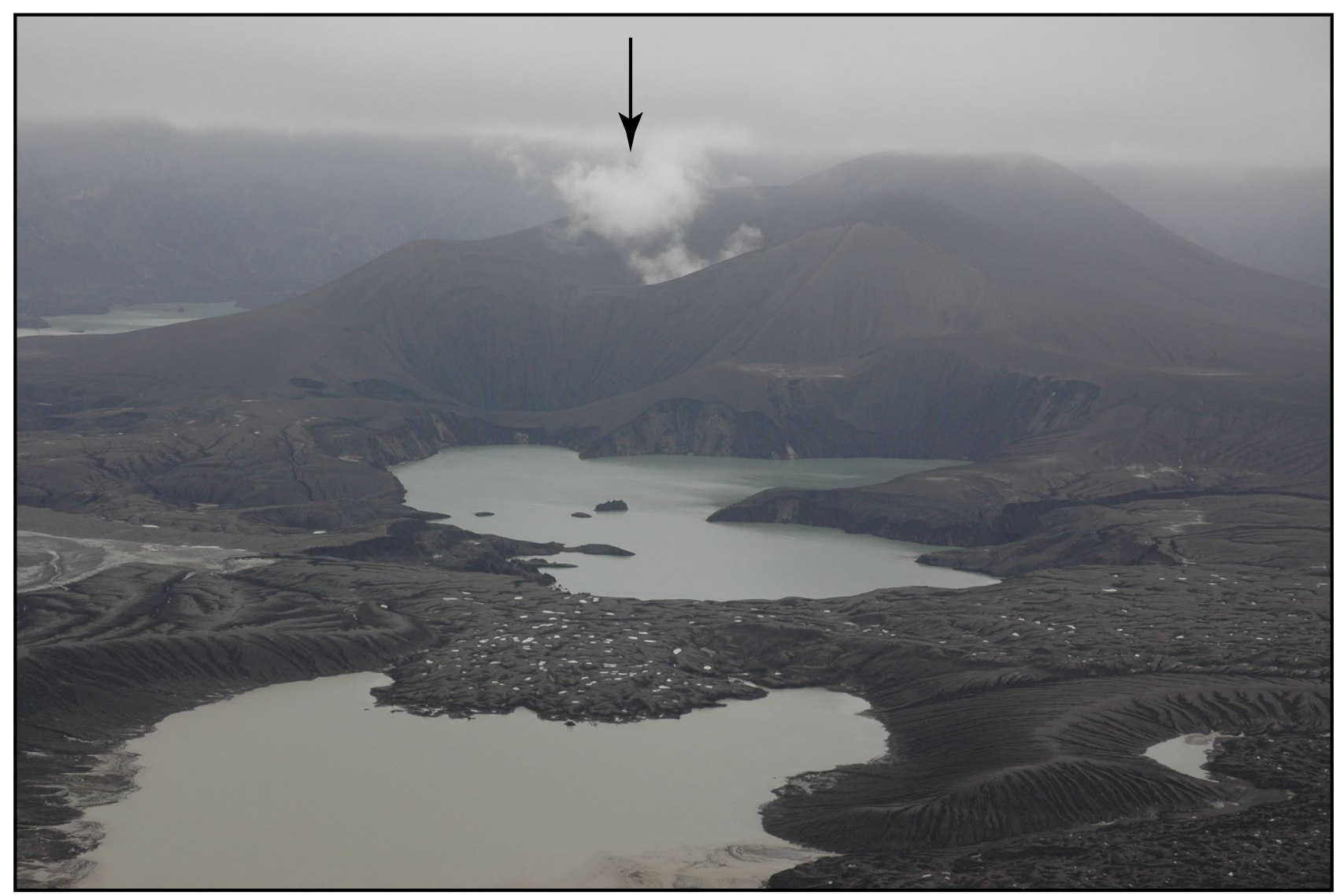

Figure 29. Photograph of the Ahmanilix cone in September 2008, showing a "puff" of water vapor (black arrow) emanating from the crater. At this time, AVO field crews were in satellite phone contact with the Anchorage office of AVO; seismologists reported intermittent bursts of tremor but overall low levels of seismicity. Compare this image with figure 17B, showing Ahmanilix in summer 2010. West Cone D lake is in the foreground; North Cone D lake is barely visible at top left on the far side of the new cone. Speckled appearance of 1997 lava flow lobe in the foreground is from small pools of standing water atop tephra-mantled, irregular 'a 'a lava flow surface. In the near-foreground, Cone J lake of Neal and others (2011; fig. 25) is a shallow, seasonallyephemeral water body that grew in size following the 2008 eruption. View is toward the east. Photograph by J. Larsen (UAFGI).

village on Umnak Island, about $75 \mathrm{~km}$ to the southwest of Okmok volcano. Between August 3 and the last confirmed ash emission on August 19, plume heights generally decreased and ash deposition was largely confined to the caldera, the caldera rim, and proximal areas beyond.

The isopach map in figure 7 shows the approximate cumulative extent and thickness of tephra deposited between July 12 and August 19 on northeastern Umnak Island. Deposits exceed 25-50 $\mathrm{m}$ thickness in the near-vent region, thinning to about $8 \mathrm{~cm}$ thick $16 \mathrm{~km}$ northeast of the 2008 vents, approximately on axis with the July 12 eruption plume. To the southwest, deposits decrease to $1 \mathrm{~cm}$ or less by $17 \mathrm{~km}$ from the 2008 vents. To the north and west of the caldera rim, ash deposition rapidly decreased to trace amounts outside the caldera; little to no ash was observed on the north to west flanks of the volcano. However, few data points in the high north and west sectors mean isopachs for that sector are approximate. In total, the isopach contours trace three overlapping lobes of on-island ash deposition with axes that extend from the vent region: (1) a main northeast lobe that extends west of Cape Idak; (2) a broad lobe to the southeast; and (3) a relatively narrow southwest lobe with lower thickness overall. In general, those three lobes correlate with the three primary plume directions observed over the course of the eruption as documented by eyewitness accounts, ash-fall reports, and satellite imagery (J. Unema, written commun., 2011).

Based on the $1 \mathrm{~cm}$ isopach contour, the maximum area of on-island dispersal is about $422 \mathrm{~km}^{2}$. However, if we include the ash-fall reports from Unalaska and Nikolski villages on Unalaska and Umnak islands, the maximum dispersal area far exceeds this minimum estimate. Applying the model of Fierstein and Nathenson (1992) and assuming exponential decay in thickness as a function of distance (Pyle, 1989), we estimate the bulk volume of the 2008 eruption deposits on Umnak Island is $0.35 \pm 0.12 \mathrm{~km}^{3}$, averaging the results of single (Pyle, 1989) and two-line segment (Fierstein and Nathenson, 1992) results. Because the majority of the deposits are fine grained, we assign a bulk volume from the MPUA measurements outside the caldera $\left(960\right.$ to $\left.1,760 \mathrm{~kg} / \mathrm{m}^{3}\right)$. The resulting estimate of deposit bulk porosity $(49 \pm 11 \mathrm{vol} . \%)$ is used to correct bulk deposit volume to dense rock equivalent 

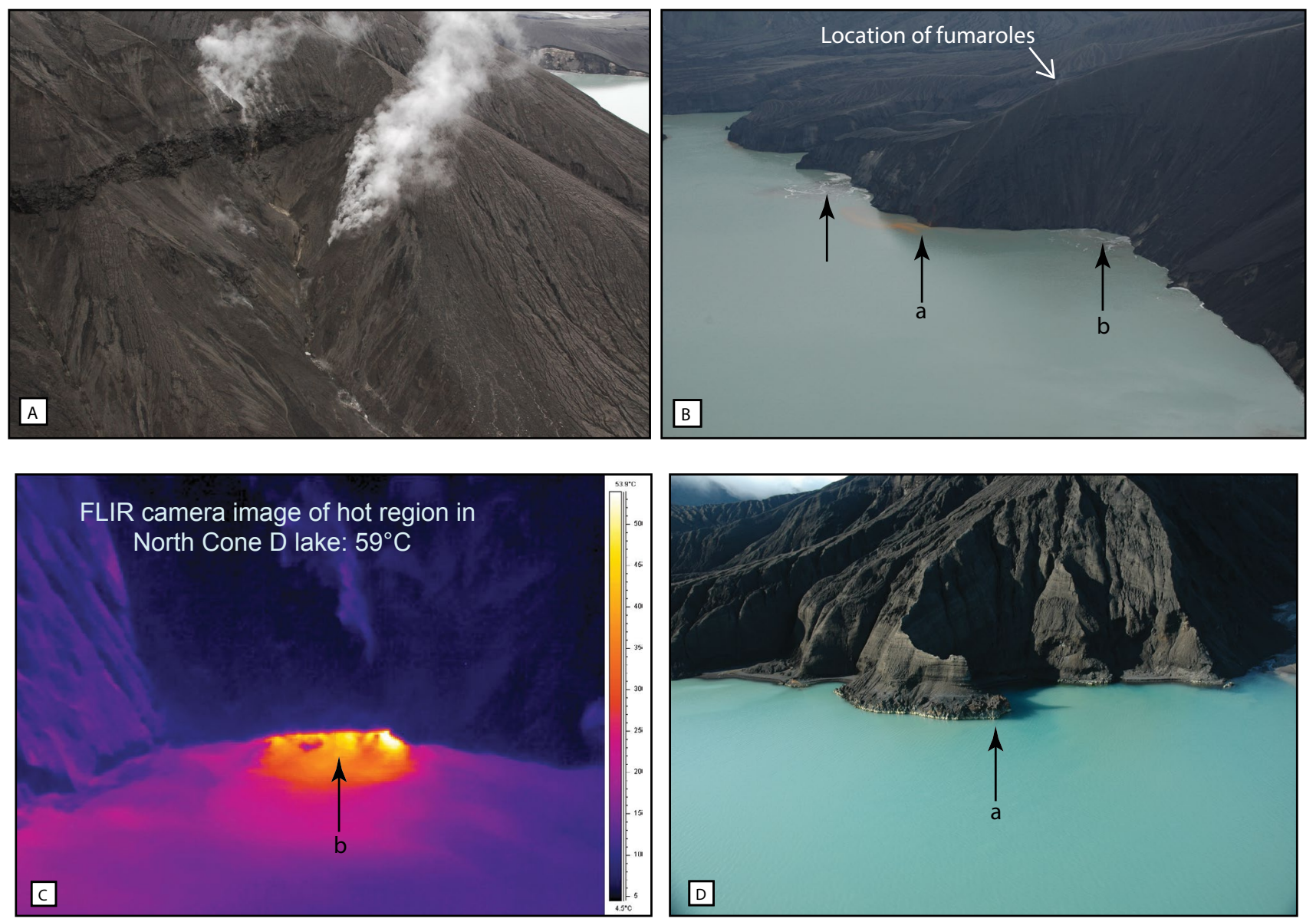

Figure 30. Oblique aerial photographs and FLIR image of the Cone D lava bench and North Cone D lake shoreline in September 2008 and August 2010. A. During 2008, fumaroles on steep, inaccessible cliff exposures of Cone D bench lavas emitted white vapor clouds. View is toward the northwest; North Cone D lake is in the distance. B. Roiling, discolored water in North Cone D lake, approximately downslope from the fumaroles in panel $\mathrm{A}$ (white arrow). Locations a and $\mathrm{b}$ in this panel correspond to a and $b$ noted in panels $C$ and $D$, showing the same point of reddish altered rock. View is toward the southeast. C. FLIR image, showing hot water temperatures at the base of Cone $D$ bench; location $b$ (black arrow) corresponds with location $b$ in panel B. The highest temperature recorded at the lakeshore was $59^{\circ} \mathrm{C}$. D. August 2010 photograph of the same region shown in panels $A$ and $B$, showing no roiling or rusty discoloration in the lake. Panels $C$ and $D$ show a view toward the south at the base of Cone D. Photographs by C. Neal (USGS) and J. Larsen (UAFGI).

(DRE). The 2008 eruption thus produced about $0.17 \pm 0.06$ $\mathrm{km}^{3} \mathrm{DRE}$ andesitic magma. Because an unknown amount of ash was deposited into the ocean surrounding Umnak Island, this is a minimum value.

\subsection{General stratigraphy of the 2008 tephra deposits}

Deposits from the 2008 Okmok eruption are predominantly planar-bedded, moderately to well-sorted ash to lapilli layers that vary in thickness from tens of meters near the vent region to trace amounts of ash at Nikolski and Unalaska. In freshly dug exposures more than a few kilometers northeast, east, and southeast from the vent, the basal unit is usually a coarse ash to fine lapilli-fall deposit. Outside the caldera, the coarsest lapilli ( $3-5 \mathrm{~cm}$ long axis) are found in this basal unit along an azimuth trending northeast from the vent (fig. 6, stations 08JFLOK013, 08JFLOK016,
08JFLOK040, 08JFLOK041). Within the caldera, summer 2010 fieldwork revealed pumice bombs up to $8 \mathrm{~cm}$ in size at station 10JFLOK015 along the northern shore of North Cone D lake, representing proximal deposition of an energetic blast deposit. This deposit is described in a discussion of proximal Ahmanilix stratigraphy in section 4.3.1, and more fully examined in Unema and others (written commun., 2014).

Overall, 2008 deposits are progressively finer grained upsection. Except for a basal breccia confined to the caldera, likely derived from the Ahmanilix vent area, we are unable to tie specific units to specific vents as a function of time. The following overview is based predominantly on location 08JFLOK016 (fig. 35). Here, a total of $2.3 \mathrm{~m}$ of 2008 deposits rests on largely undisturbed snow. The lower unit consists of $\sim 40 \mathrm{~cm}$ of predominantly lapilli-size juvenile scoria and lithic clasts. At the base (fig. 35, layer 1) is a $12.7 \mathrm{~cm}$ layer of moderately well sorted lapilli, with most 

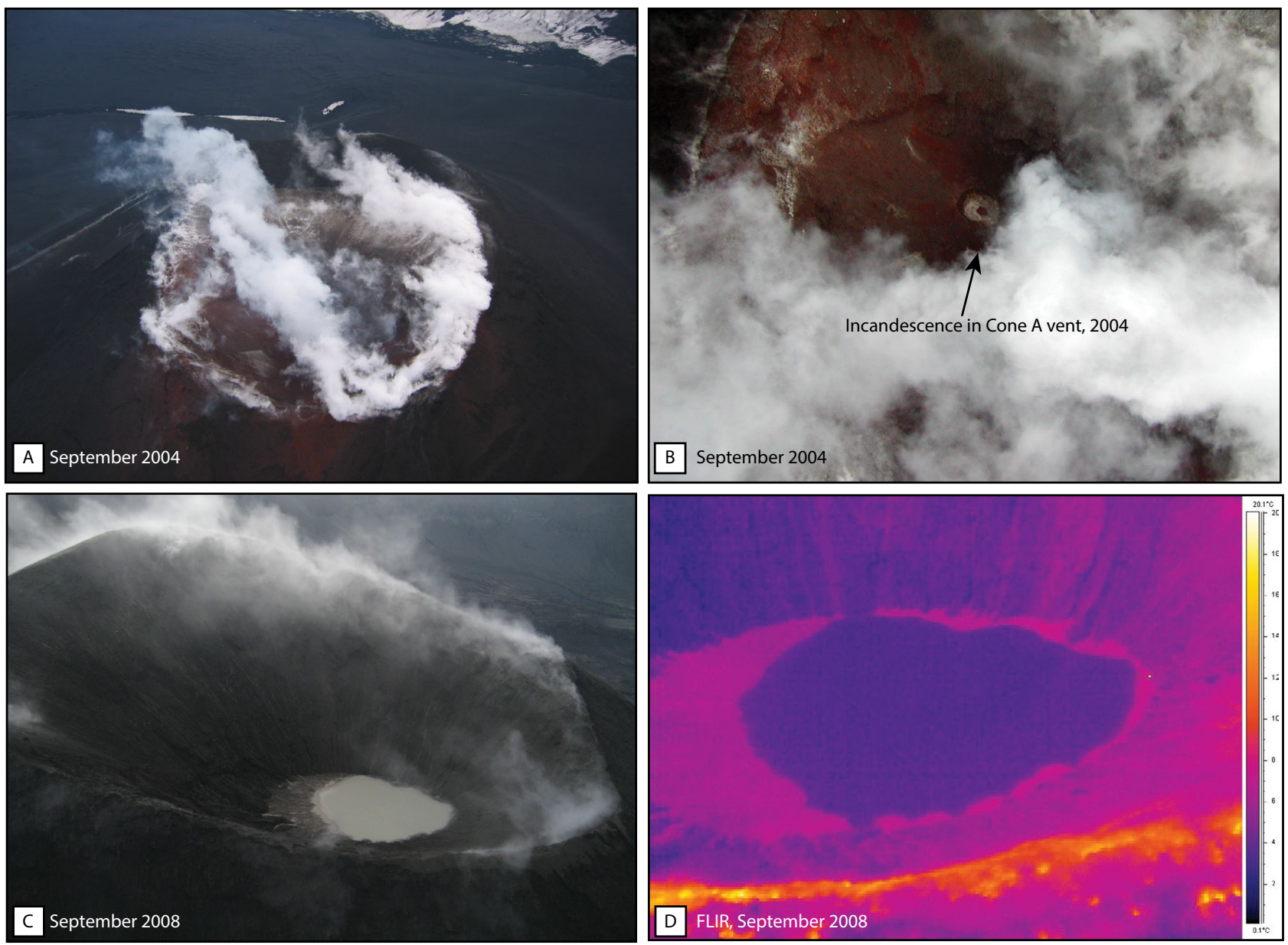

Figure 31. Oblique aerial photographs and FLIR images of Cone A through time. A. View of Cone A summit in September 2004, with prominently steaming northern summit crater. Photograph by C. Nye (DGGS). B. View down into the summit crater, showing incandescent orifice on the crater floor in September 2004. Photograph by J. Schaefer (DGGS). C. Aerial view in September 2008, showing standing water in the northern summit crater and steaming around the rim. Photograph by M. Kaufman (UAFGI). D. September 2008 FLIR image showing the cold interior of the northern summit crater at Cone A. Maximum rim temperatures were approximately $56^{\circ} \mathrm{C}$. Image by J. Larsen (UAFGI).

scoria 1-2 $\mathrm{cm}$ in size, and maximum clasts of $3-5 \mathrm{~cm}$. The scoria fragments are coated by a distinctive olive to tan colored, very-fine-grained ash that was still wet when first examined in early September 2008. Above this basal layer, the unit transitions to a $\sim 6$-cm-thick horizon with a 0.5-2 mm coarse-ash to fine-lapilli matrix, and scattered lapilli $1-1.5 \mathrm{~cm}$ in diameter (fig. 35, layer 2). The muddy, fine-grained ash coating the larger juvenile grains is much less apparent here. Above this, the unit shows two intervals of coarser- and finer-grained layers. The first interval is $\sim 12 \mathrm{~cm}$ thick and contains juvenile clasts up to $1.5 \mathrm{~cm}$, with lithic fragments up to $4.5 \mathrm{~cm}$ in size at its base. The remainder above contains finer-grained matrix of 0.2 to 2 $\mathrm{mm}$ coarse-ash to fine-lapilli matrix, with juvenile scoria up to $2 \mathrm{~cm}$ in grain size (fig. 35, layer 3). The next interval is approximately $10 \mathrm{~cm}$ thick, and consists of a coarse base and finer-grained top (fig. 35, layer 4). The coarse layer contains lithic fragments between 3.75 and $5.5 \mathrm{~cm}$ in size with mostly subrounded to subangular shapes. The finer-grained layer consists of poorly sorted, 0.5 to $2 \mathrm{~mm}$ coarse-ash to fine-lapilli matrix, with some juvenile and lithic fragments between 1.5 and $2 \mathrm{~cm}$ in size.

The remaining $\sim 190 \mathrm{~cm}$ of the 08 JFLOK016 stratigraphic section is predominantly fine-grained ash, with intervening medium- to coarse-ash layers throughout (fig. 35, layer 5). Because it is difficult to correlate these upper beds with stratigraphic sections studied in September 2008, we will describe the general upper deposit characteristics. Stratigraphic descriptions are divided into seven separate ash layer 'packets.' These packets were variably wet to dry; some layers were supersaturated with water during September 2008. The wetter layers contain fragile, 2- to 3-mm-diameter fine-ash aggregates. During summer 2010, the aggregates were still visible in distinct layers. Structurally, the layers in the upper part of the 08JFLOK016 stratigraphic section are variably massive to laminated, with no cross-bedding. The upper $60 \mathrm{~cm}$ of this section contains fine- to very-fine-grained ash in layers that are massively 


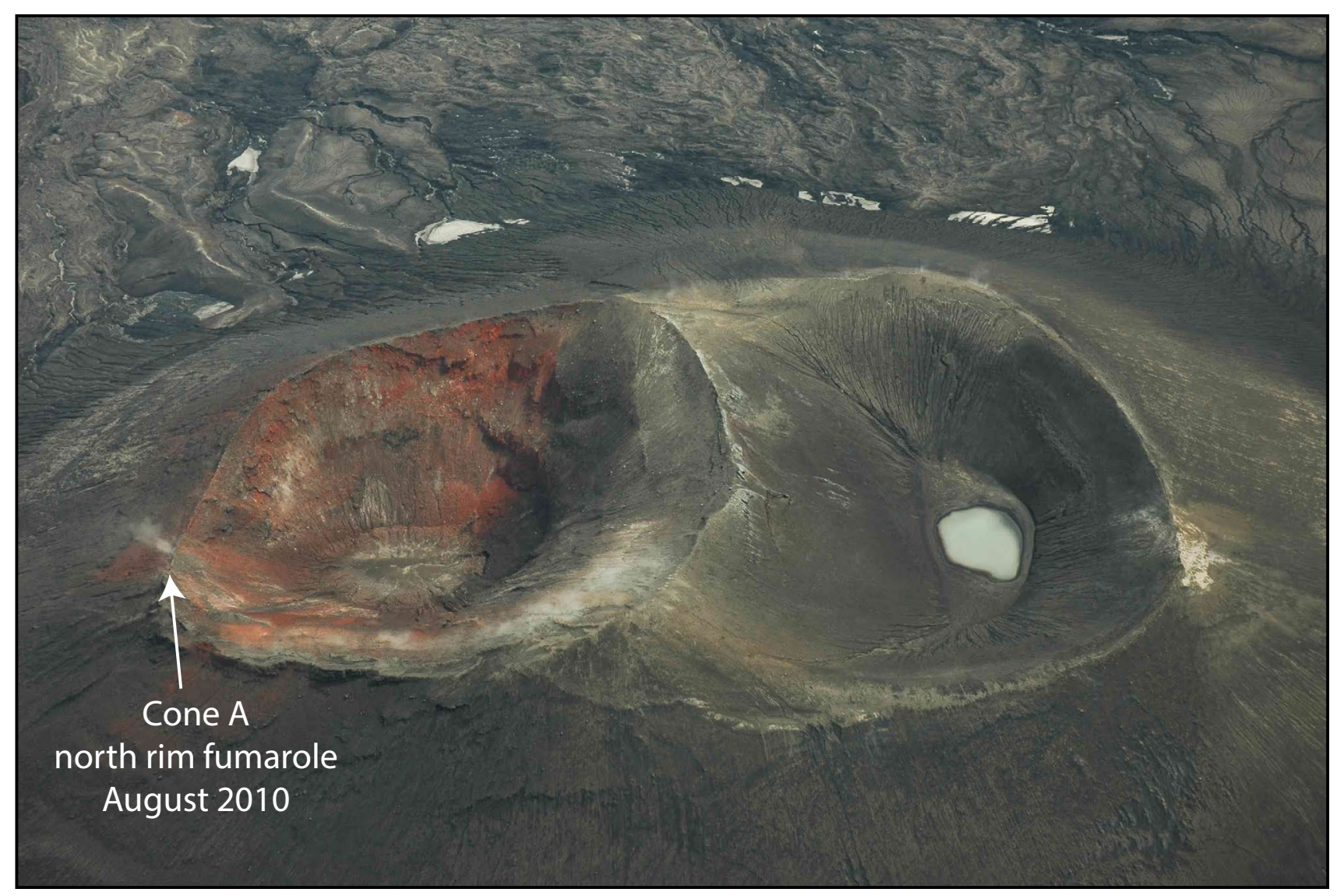

Figure 32. August 2010 oblique aerial photograph of the summit craters of Cone A. The northern crater (left) exhibits faint fumarolic emission (arrow) from its rim. The southern crater hosts a small pond. Photograph by J. Larsen (UAFGI).

to faintly laminated, containing very faint, discontinuous lenses filled with light-brown ash. The base of this $60 \mathrm{~cm}$ unit is porous and vuggy.

Coarse pumice fragments $>5 \mathrm{~cm}$ in length were found as 'float' in the high tide line along the northeastern coast of Umnak Island, sampled at location 08JFLOK013, and along the shorelines of two caldera lakes (sites CNOK08-04 and CNOK08-05) (fig. 6). Similar, slightly rounded pieces of floating brown pumice were reported and sampled from beaches around Unalaska village and Dutch Harbor on Unalaska Island. Although first interpreted as 2008 pumice, 2010 fieldwork identified an older source. Along upper Crater Creek, pumice-fall deposits from the 1817 eruption immediately inside the Gates were excavated by 2008 lahars and pumice clasts were washed downstream into the Bering Sea (fig. 36.)

\subsection{Surface water changes in the caldera}

Surface and shallow groundwater flow inside the caldera is dominated by drainage from higher elevations in the south ( $\sim 1,020 \mathrm{~m}$ at base of southern caldera wall) toward lower elevations in the north $(360 \mathrm{~m}$ where Crater Creek exits the caldera). Prior to 2008 , a gently sloping alluvial basin devoid of primary vent features extended from the center of the caldera toward the northwest region of the caldera. Byers (1959) described this portion of the caldera as 'swampy', indicating persistent shallow groundwater conditions. In 1958, a blocky 'a'a lava flow partially filled this alluvial basin from Cone A to the caldera wall north of cone $\mathrm{D}$, damming surface water and creating Cone D lake (figs. 3 and 4).

Pre-2008 field observations and satellite images show the dominant surface water features (fig. 37) consisted of (1) a debris-covered, perennial ice and snow field (surface area $2.7 \mathrm{~km}^{2}$ ) against the southern inner wall of the caldera at elevations between 600 and 1,020 m ASL, (2) Cone D lake (elevation $\sim 380 \mathrm{~m}$ from 2000 AirSAR data; maximum depth $\sim 25 \mathrm{~m}$; volume $13.6 \times 10^{6} \mathrm{~m}^{3}$; surface area $1.3 \mathrm{~km}^{2}$ ), (3) shallow lakes in craters and depressions near the intracaldera cones E, G, H, and J, (4) seasonal ephemeral lakes in areas constrained by local topography, and (5) active fluvial channels draining the caldera toward Crater Creek and the Gates. Prior to the 2008 eruption, the total area of permanent surface water features, excluding the snow and ice field, was $\sim 2 \mathrm{~km}^{2}$.

Fine, wet, relatively impermeable tephra blanketed the caldera during the 2008 eruption and caused meteoric water to preferentially run off rather than infiltrate the ground. This resulted in widespread and severe gullying and erosion, both inside the caldera and on its outer flanks. Rapid runoff and sediment transport to intracaldera lakes accelerated lake refill. 

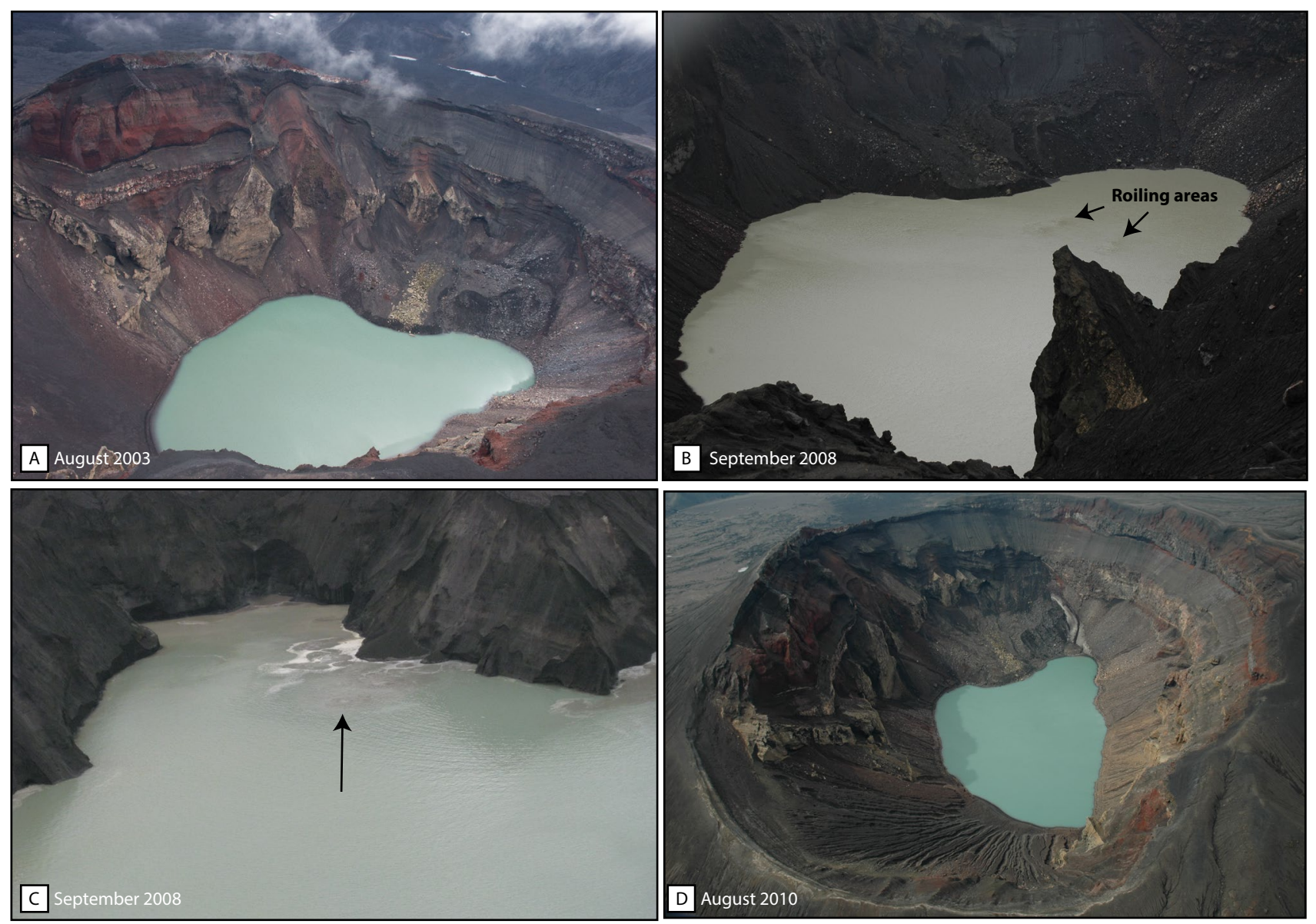

Figure 33. Oblique aerial views of Cone E lake through time. A. Prior to the 2008 eruption, the Cone E lake was bluish-green with no visible signs of thermal upwelling. Photograph taken summer 2003 by C. Nye (DGGS). B. In September 2008, AVO observers noted multiple point sources of roiling or upwelling. The suspended 2008 ash deposited into the lake is the likely cause of the color change to greenish-gray. C. Close-up view of roiling in Cone E lake in September 2008. Discoloration is partly due to fine ash in suspension. D. View of the entire Cone E crater and lake in summer 2010, showing no obvious signs of roiling, and a return to bluish-green color. Photographs B-D by J. Larsen (UAFGI).

Approximately one month after the eruption's end, in September 2008, the area of standing surface water in the caldera had increased to $\sim 3 \mathrm{~km}^{2}$. The most significant changes were the creation of West Cone D lake and the westward expansion of North Cone D lake. Dammed by 2008 tephra accumulation that impeded drainage through the now-buried 1997 lava flow, a shallow, ephemeral lake formed to the southwest of Cone D. This lake disappeared by summer 2010, likely due to drainage around the eastern base of Cone D into the headwaters of Crater Creek. Standing water was visible in many collapse pits north of Cone D as well as in small depressions on the relatively impermeable, fine-grained, water-saturated tephra deposits atop the 1817 lava flow between Cone D and the Gates. Water accumulated in the Cone A summit, forming a pool of standing water in both craters, indicating significant cooling of the cone over the past few years, since the last reported observation of incandescence within one of Cone A's summit craters, noted in 2005 (fig. 37).

The eruption also caused changes that resulted in loss of surface water in the northwest part of the caldera; Lake $\mathrm{H}$ and
Cone B lake drained completely, creating dendritic channels in exposed lake-bottom sediment (figs. 37 and 38). Prior to the 2008 eruption, these lakes had no direct surface-water outlets and likely drained by shallow subsurface seepage through porous volcanic sediments. Lake $\mathrm{G}$ remained apparently unchanged, and the volumes of Lake E and the seasonal lake west of Cone E increased slightly.

Caldera lake surface elevations measured in September 2008 document a clear gradient of lake levels across the caldera floor (fig. 38). North Cone D lake (OLD8) had a measured elevation of $344 \mathrm{~m}$; West Cone D lake (OLL8) was 353-357 m; the small lakes by Cone J (OLG8) and Cone C (OLC8) had respective elevations of $389 \mathrm{~m}$ and $435 \mathrm{~m}$. The estimated vertical error on these measurements is less than $\sim 2 \mathrm{~m}$.

Shoreline changes in areas of previously standing surface water indicate that by September 22, 2008, the water in the collapse pits and cones B, C, and J lakes were receding, and water levels in West Cone D lake and new North Cone D lake were increasing (fig. 37). The zones of receding water 
Figure 34. Oblique aerial views of Cone C, showing weak summit fumarolic activity through time. Arrows mark the location of a long-lived thermal area along the rim of one of the summit craters. A. View to the north taken September 2004. Photograph by C. Neal (USGS). B. Photograph of the Cone $C$ summit in 2010. Discolored area around the rim likely reflects continuing fumarolic activity. Photograph by J. Larsen (UAFGI). C. Photograph of Cone C summit craters taken mid-January 2011 by pilot Burke Mees and used with permission. Visible vapor plume shows the location of fumarolic activity along the largely snowfree rim of the summit crater also shown in panels $A$ and $B$.

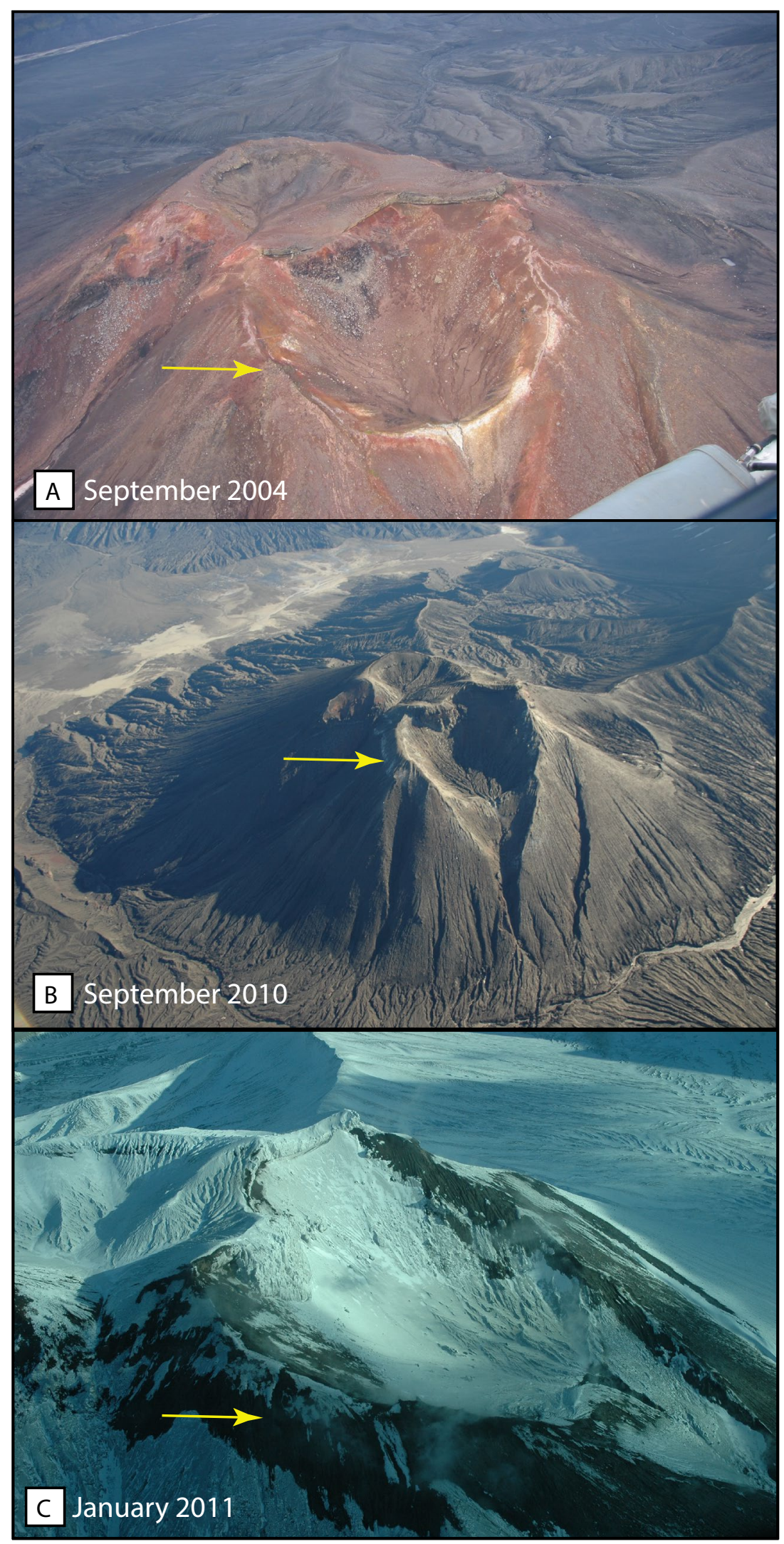




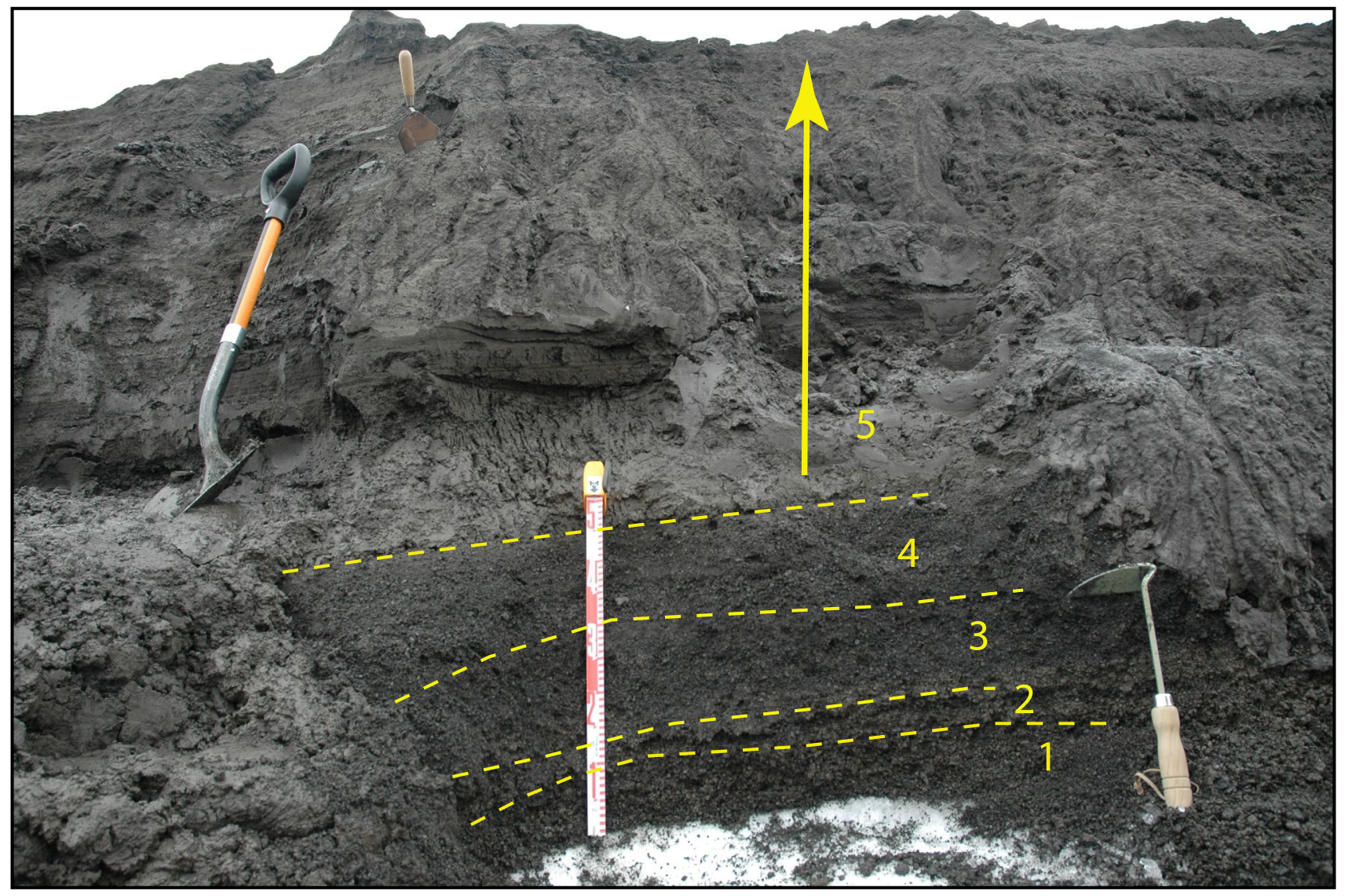

Figure 35. Representative stratigraphic section from location 08JFLOK016 (fig. 6), showing water-saturated 2008 eruption deposits along the northeast-trending depositional lobe (fig. 7). Photograph shows the first-erupted, coarse-grained basal units (layers 1-4) that fell on snowpack. These are overlain by much finer grained (medium to fine ash) layers (undifferentiated in this photograph, labeled layer 5) that dominate the upper approximate two-thirds of the section. Ruler is $50 \mathrm{~cm}$ long. Photograph taken in September 2008 by J. Larsen (UAFGI).

likely indicate areas where water was temporarily perched atop water-saturated, variably permeable fine-grained tephra deposits. The increasing sizes of West Cone D lake and North Cone D lake indicate that the subsurface water flow in the caldera was not drastically altered by the eruption, and that water still flowed toward the previously existing basin north and west of Cone D. The disappearance of lakes H (elevation $\sim 380 \mathrm{~m}$, same elevation as Cone D lake) and B (elevation $\sim 430 \mathrm{~m}$ ) likely indicates a lowering of the shallow groundwater in that region (fig. 37). As groundwater is recharged and the water level rises in North Cone D lake, we expect reactivation of previous fluvial pathways and the caldera to drain as it did pre-eruption.

\subsection{Lahars generated during and after the 2008 eruption}

Lahars significantly impacted all sectors of the flanks of Okmok Caldera during and after the 2008 eruption (fig. 39). The exact timing of major lahar activity during the first days of the Okmok eruption is unknown; however, between eruption onset on July 12 and Lonnie Kennedy's return to the island on July 23, lahars inundated low-lying areas east of the caldera near Fort Glenn ranch and caused significant damage to roads around the ranch. During the first 11 days of the eruption, lahars in several drainages north of the ranch destroyed wooden bridges and culverts and caused severe bank erosion. Between July 23 and 31, lahar activity continued near Fort Glenn and large deltas formed at the mouths of several creeks draining the northeast and southeast flanks of Okmok. Lahar activity continued, at an apparently much lower discharge rate, through September 2008 in many of the larger drainages. At that time, stream channels contained muddy discharge and produced sediment plumes emptying from the lahar deltas into the Pacific Ocean to the south and the Bering Sea to the north.

During the late July-early August and September 2008 field visits to Okmok, a dense network of deeply incised rills had already formed in the new tephra deposits on the upper flanks of the volcano (fig. 40). Rills coalesced downslope into larger channels that led to upper reaches of both minor and major stream channels. Field observations also describe significant snowpack trapped underneath thick ash deposits and, in places, blocks of snow tumbled into the drainages, perhaps due to bank erosion by lahars. Surface water runoff, 

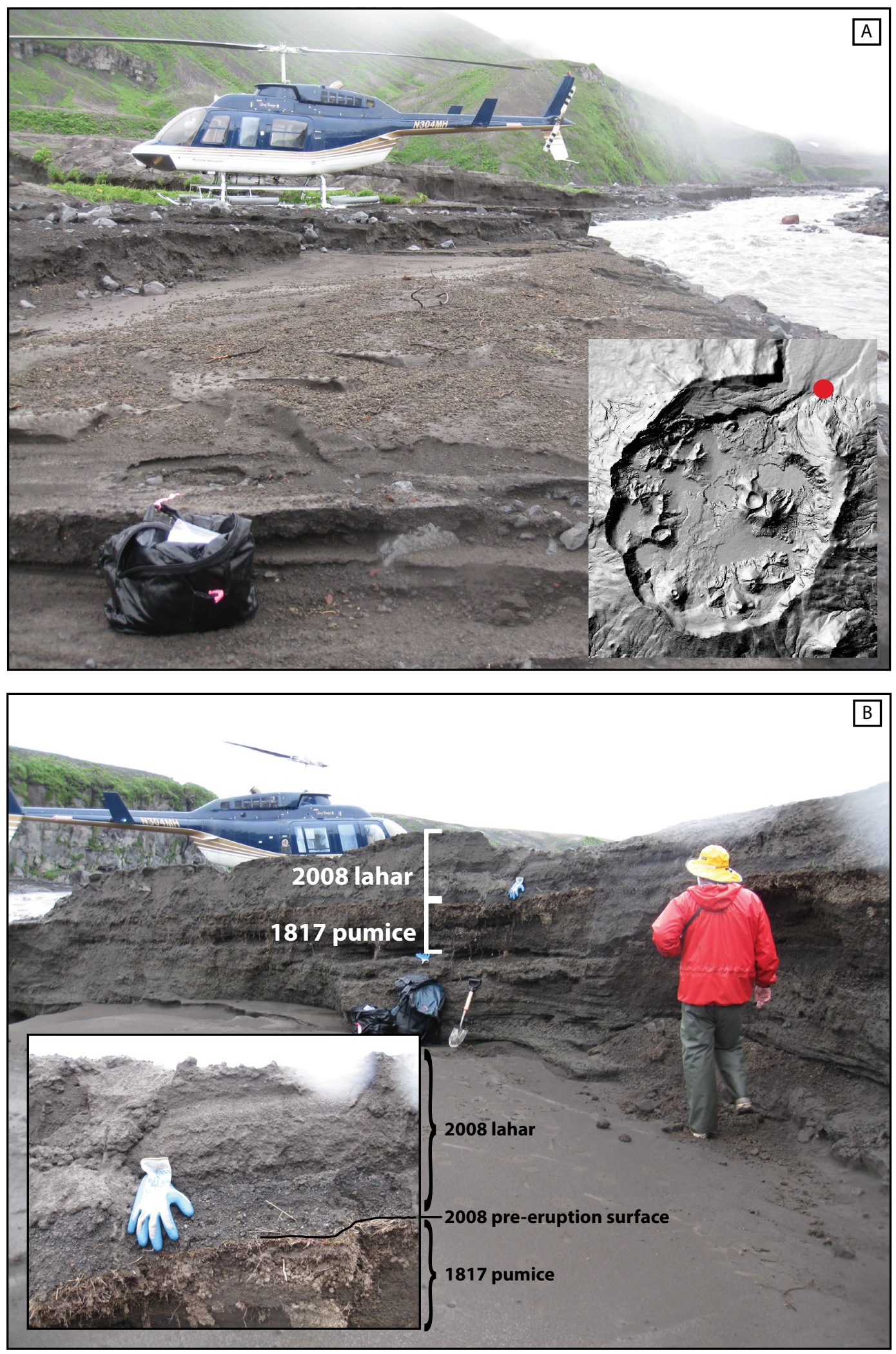

Figure 36. Likely source of pumice that washed ashore in Unalaska within days of the onset of the 2008 eruption. A. Pumice clasts, redistributed after lahars scoured and exposed older deposits, litter the surface of 2008 lahar deposits in Crater Creek. Stations 10JRSOK003 and 004; location indicated by red circle on inset map. B. Newly exposed cut-bank along Crater Creek reveals a concentration of 1817 pumice just below the 2008 lahar. Inset shows close-up of the vegetated 2008 pre-eruption surface, the concentrated zone of 1817 pumice below, and 2008 lahar deposits on top. 

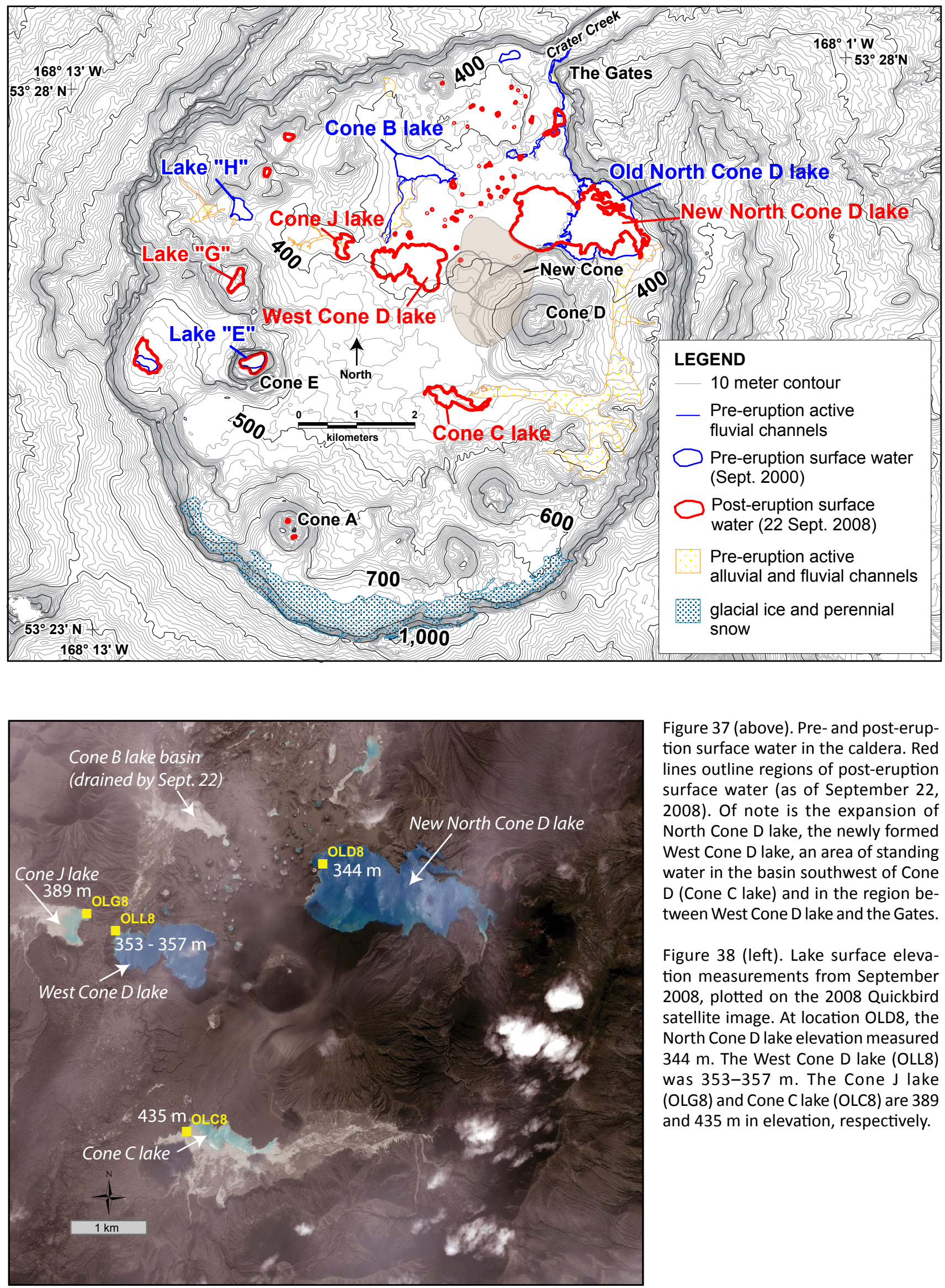

Figure 37 (above). Pre- and post-eruption surface water in the caldera. Red lines outline regions of post-eruption surface water (as of September 22, 2008). Of note is the expansion of North Cone D lake, the newly formed West Cone D lake, an area of standing water in the basin southwest of Cone $D$ (Cone $C$ lake) and in the region between West Cone D lake and the Gates.

Figure 38 (left). Lake surface elevation measurements from September 2008, plotted on the 2008 Quickbird satellite image. At location OLD8, the North Cone D lake elevation measured $344 \mathrm{~m}$. The West Cone D lake (OLL8) was $353-357 \mathrm{~m}$. The Cone J lake (OLG8) and Cone Clake (OLC8) are 389 and $435 \mathrm{~m}$ in elevation, respectively. 


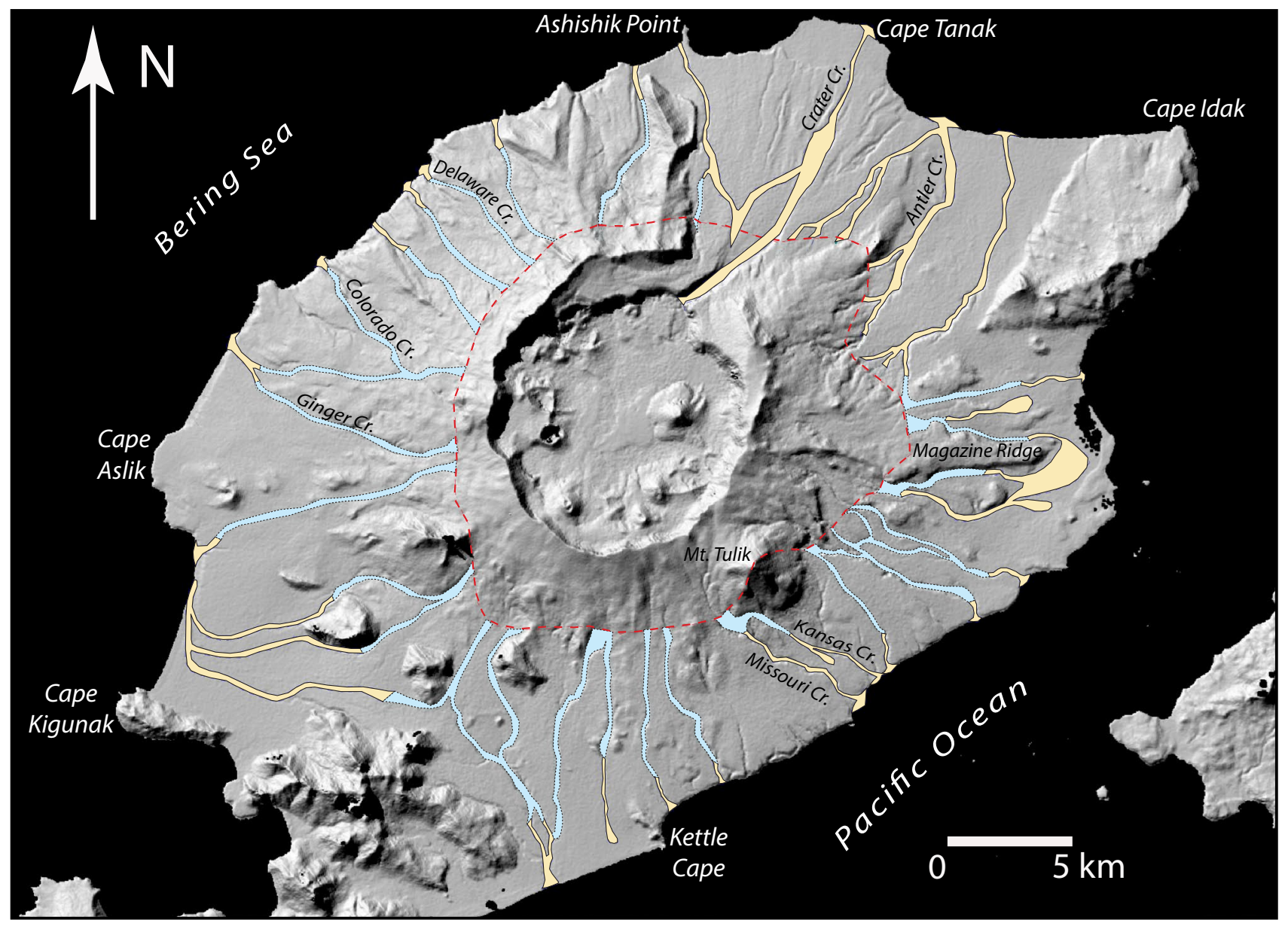

Figure 39. Map of lahar deposits in drainages around the flanks of Okmok volcano during and after the 2008 eruption. Yellow polygons with solid borders show lahar deposits observed in September 2008. Blue polygons with dotted borders indicate inferred upstream extent of continuing lahar deposits; these regions were either inaccessible or not observed during September 2008 because of poor weather. Red dashed region indicates the upper flanks of the volcano where extracaldera ash deposits were thickest. Deep rills observed in this area suggest it was the source region for most lahars. Lahars down Crater Creek likely began higher on the flanks of the volcano in the Gates region.

with a lesser amount of incorporated snowmelt, formed the bulk of the water that created voluminous lahars that reached the coast in nearly all major stream drainages. Additional water sources that may have contributed to flow volume are syneruptive condensation of water vapor from the eruption cloud (W. Scott, written commun., 2008) and gradual dewatering of wet tephra-fall deposits.

The largest lahars produced overbank deposits, suggesting flow capable of more than $10 \mathrm{~m}$ of super-elevation in some locations. The larger lahars carried boulders up to $3 \mathrm{~m}$ in diameter, and meter-scale sod chunks were ripped from channel banks and carried downstream. Overbank deposits and the presence of large boulders atop the surface of the 2008 lahar fans at the mouth of Crater Creek to the north and Missouri Creek to the south are consistent with temporarily high discharge rates (figs. 41 and 42). Measurements of channel depth near the point at which the lahar in Missouri Creek overtopped the bank indicate that the flow depth exceeded $5.5 \mathrm{~m}$ (fig. 42A). On September 9, 2008, the channel was $\sim 32 \mathrm{~m}$ in width. The flow speed was great enough to transport boulders larger than $1 \mathrm{~m}$ in diameter (fig. 42B).

Figures 41 and 43 show the evolution of a new, prominent lahar delta built at the mouth of Crater Creek at Cape Tanak on the northern coast of Umnak Island. Cape Tanak is itself a prominent sediment fan that has prograded into the Bering Sea by accumulation of successive lahar and flood deposits exiting the caldera along Crater Creek (Wolfe, 2001). During the 2008 eruption, lahars built a new delta stretching approximately $260 \mathrm{~m}$ farther into the Bering Sea (fig. 43C), as measured by handheld GPS on September 12, 2008. The lateral extent of the delta, measured along the pre-eruption shoreline, was $830 \mathrm{~m}$. An estimate of the "maximum" area of the delta, as observed on September 11, 2008, is $\sim 2.2 \times$ $10^{5} \mathrm{~m}^{2}$.

Continued stream-channel runoff increased the sizes of most new lahar deltas between August 2 and September 11, 2008 (fig. 43). By August 2010, the Crater Creek lahar delta had eroded significantly back toward the original beach berm 
Figure 40. Oblique aerial photographs of dense rill network on upper and medial volcano flanks. A. View from August 2, 2008, during the eruption, showing finely rilled upper flanks and eastern caldera rim. The smaller rills (arrow a) coalesce downslope into larger rills and feed lahars into the major stream channels (arrow b). B. View to the north of deeply-incised rills on the caldera's inner northeast rim. The rills that eroded down through the pre-eruption snow pack are covered with dark brown tephra. The yellow arrow points to an example of eroded snowpack. Photograph taken September 14, 2008, by C. Neal (USGS). C. Lahars moving through rill drainages and then down Antler Creek (shown here) further undercut blocks of snow (arrows) that fell into the stream channels. The erosion of the snowpack is a secondary source of water, with surface runoff largely responsible for the rilling. Photograph by J. Larsen (UAFGI).
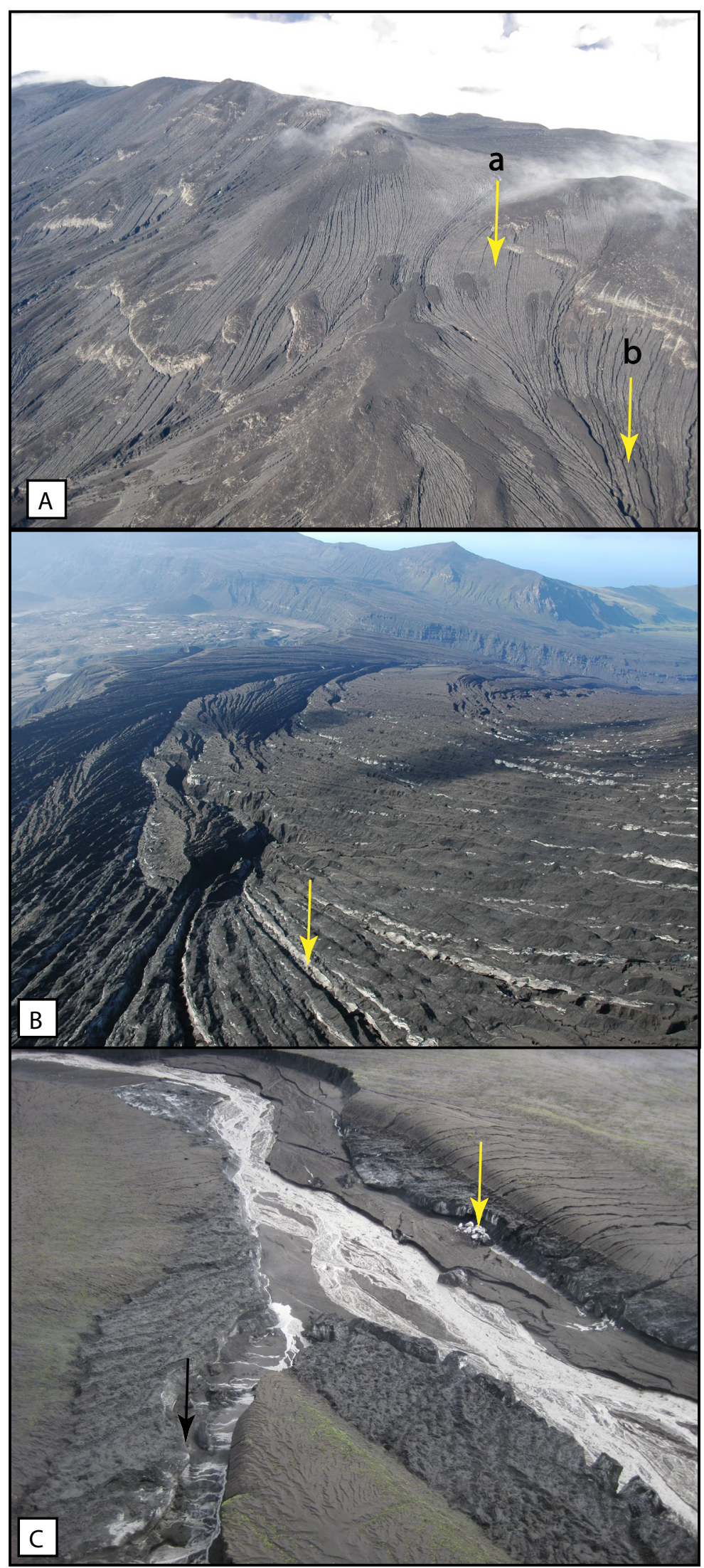


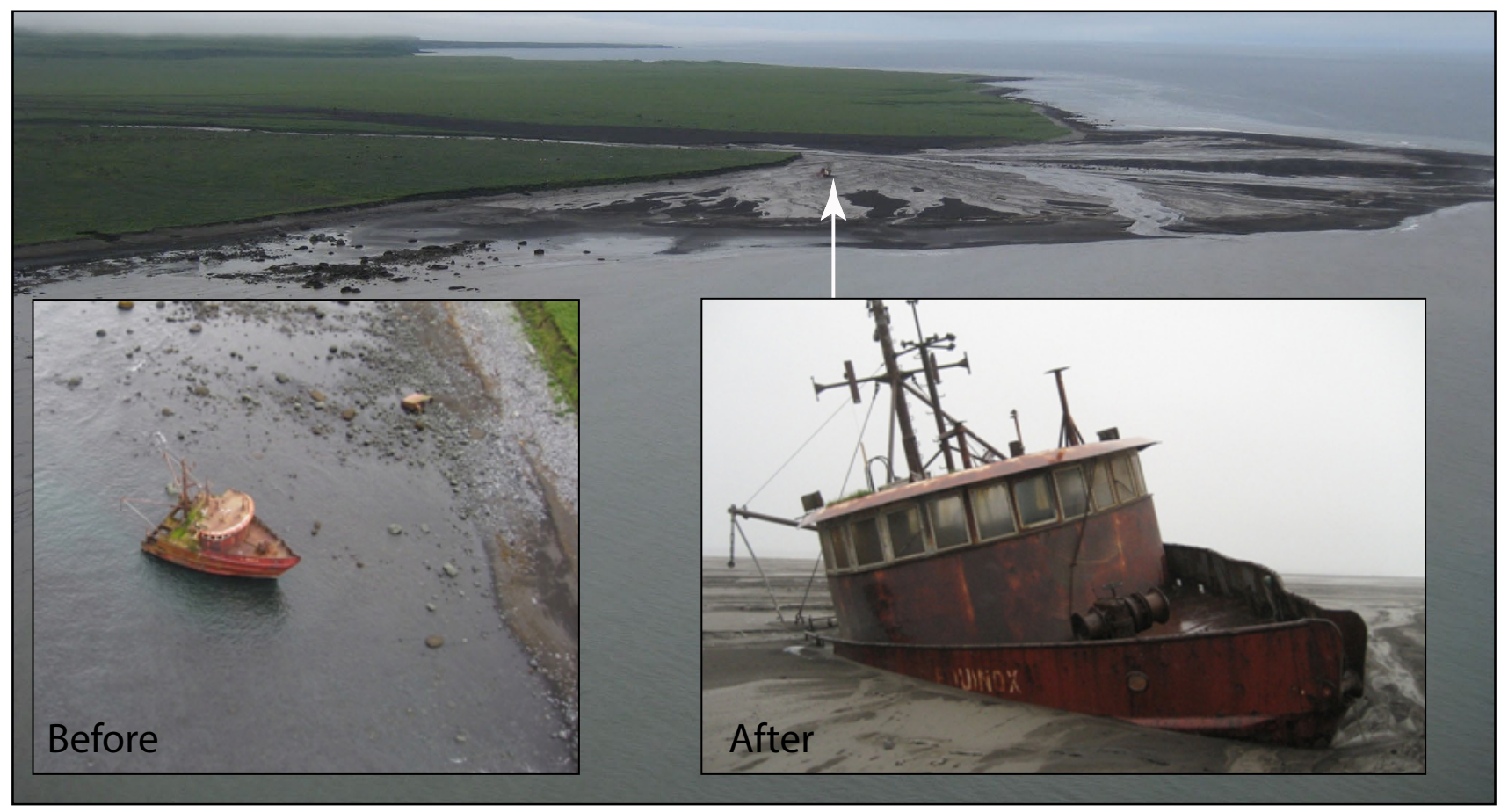

Figure 41 (above). Oblique aerial photograph taken August 2, 2008, showing the new lahar deposit delta at the mouth of Crater Creek where it empties into the Bering Sea at Cape Tanak on the northern coastline of Umnak Island (fig. 39). The view is to the west along the shoreline. Arrow points to remains of the 17-m-long Equinox, a ship that ran aground at Cape Tanak. Photograph by J. Larsen, UAF/GI). The left inset shows the Equinox on August 12, 2003, five years prior to the eruption, and the right inset shows the Equinox in September 2008 after inundation by the sediment carried by 2008 lahars. The visible portion of the Equinox hull is approximately 2-3 $\mathrm{m}$ tall. Photograph by Max Kaufman (UAFGI).

Figure 42 (right). Lahars transported large boulders in the Missouri Creek drainage on the south flank (fig. 39) of Okmok. A. Oblique aerial photograph shows evidence of a flood overtopping the channel at a change in slope (see area stripped of vegetation). Measurements of channel depth at approximately the point of breakout (arrows) indicate the lahar was $5.5 \mathrm{~m}$ deep at this point, with a channel width of $32 \mathrm{~m}$. B. Photograph looking up-channel at large boulders deposited by the lahar shown in panel $A$. Boulders transported locally by the lahar were up to $>1 \mathrm{~m}$ in diameter ( $0.6 \mathrm{~m}$ shovel for scale). Photographs by J. Larsen (UAFGI).

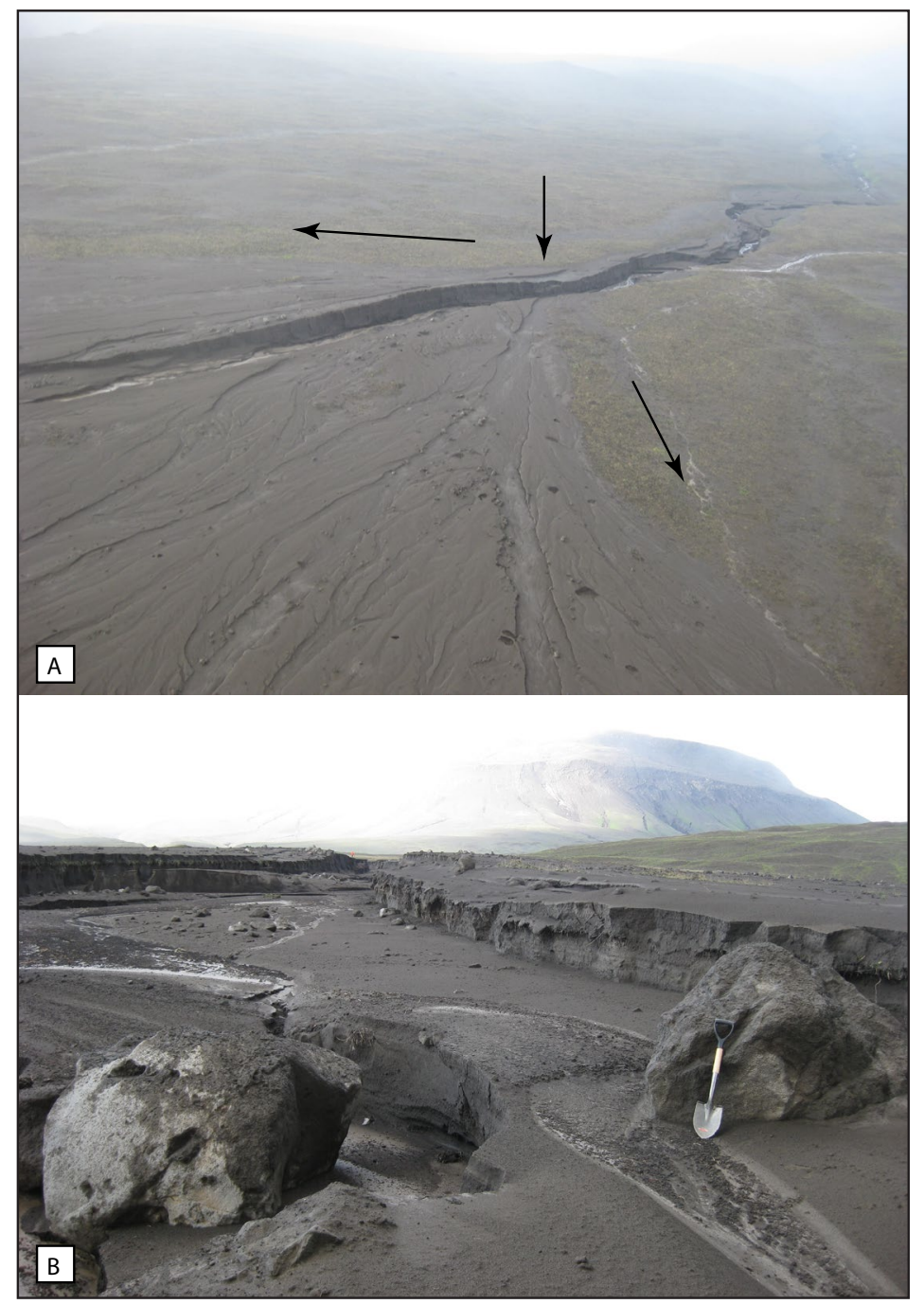




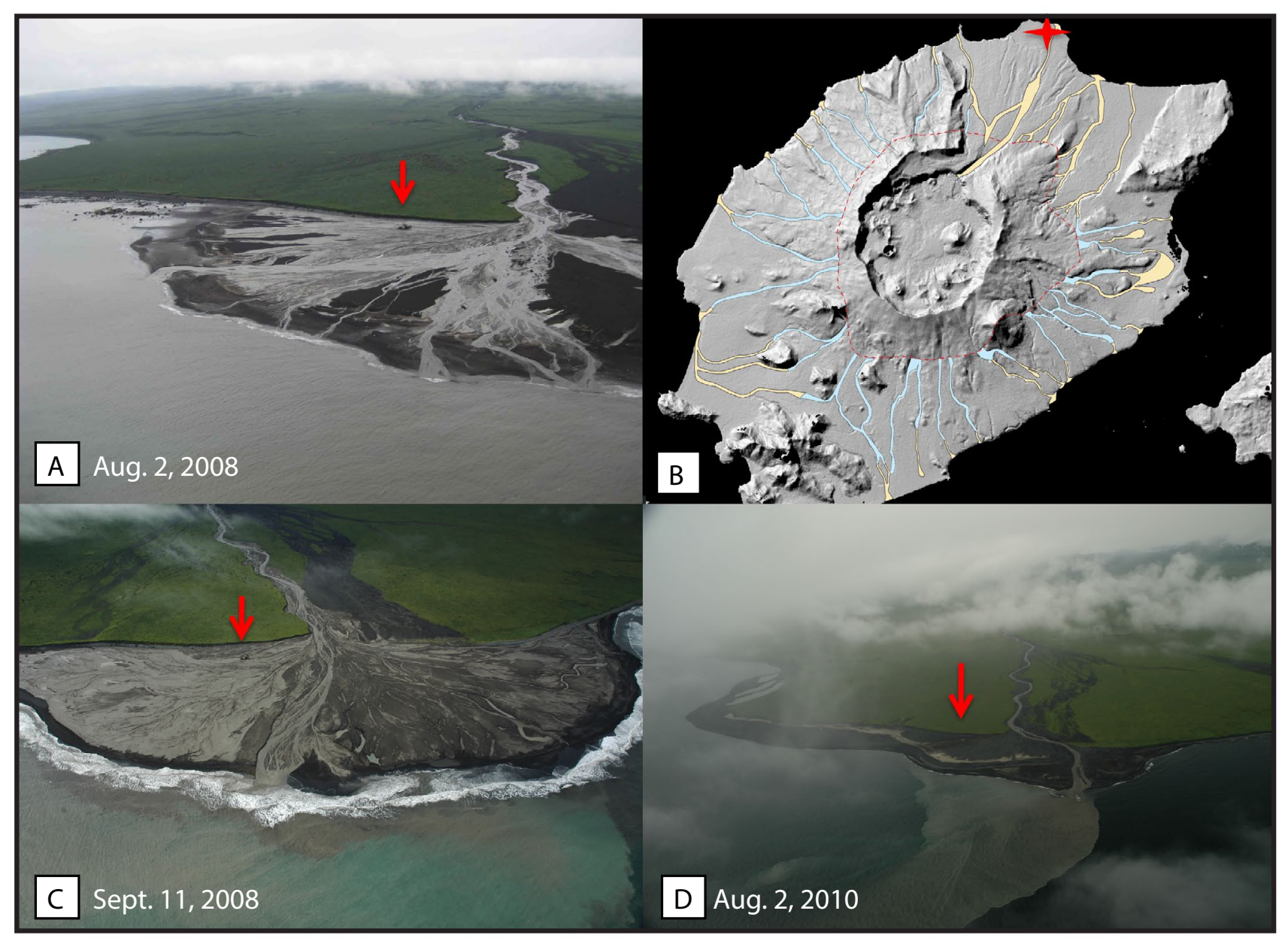

Figure 43. Oblique aerial view of the 2008 lahar delta at Cape Tanak through time. A. Photograph of the lahar delta actively forming on August 2, 2008, during the eruption. Note the significant muddy discharge into the Bering Sea. B. Location of Cape Tanak and the lahar delta (red star). C. September 2008 photograph of the significantly enlarged delta. Muddy discharge into the Bering Sea continued at this time. D. Photograph taken August 2, 2010, showing delta erosion. Littoral transport of sediment created a new, wider beach along the shoreline southeast of the creek mouth. Muddy discharge still continued from Crater Creek. Photographs by J. Larsen (UAFGI).

(fig. 43D), but the 2008 coastline remained slightly modified with a wider, longer beach and sediment fan at the mouth.

By summer 2010, all 2008 lahar deltas at the mouths of large stream channels along the southern and northern coastlines had significantly retreated landward, yet broader longshore beaches remained. Sediment discharge from the streams was greatly reduced between September 2008 and July-August 2010, yet muddy discharge continued even two years after the end of the eruption (fig. 43D).

\section{DISCUSSION}

\subsection{Eruption Mechanism}

\subsubsection{Size and explosivity in comparison with recent Okmok eruptions}

VEI (Volcanic Explosivity Index) is frequently used to classify the overall explosivity of eruptions, and is based on total erupted volume and plume height (Newhall and Self, 1982). The Okmok eruption produced a minimum $0.17 \pm$ $0.06 \mathrm{~km}^{3}$ DRE (dense-rock equivalent) andesitic magma and a maximum plume height of $16 \mathrm{~km}$, thus falling within the lower range of a VEI 4 event. Following the initial 16-kmhigh plume on July 12, plume heights waxed and waned between 1 and $12 \mathrm{~km}$ through early August (Larsen and others, 2009). A lower VEI number is more accurate to describe the later part of the eruption.

Prior Okmok eruptions range from very small and nonexplosive (VEI 1) to highly explosive, caldera-forming VEI 6 eruptions. Prior to 2008, three significant and moderatelywell-documented eruptions from Cone A (1945, 1958, and 1997) in Okmok Caldera were volumetrically 3-10 times smaller than the 2008 eruption. Those three eruptions were predominantly effusive, yet Strombolian to Hawaiian fountaining activity produced modest ash clouds that rose $3-6 \mathrm{~km}$ ASL (McGimsey and Wallace, 1999; Grey, 2003). There was a single pilot report of an ash cloud as high as $9 \mathrm{~km}$ on March 11, 1997. Those three eruptions are considered VEI 2 to 3 (Siebert and others, 2010). 
The one exception to the historically effusive eruption pattern is the 1817 eruption from Cone $\mathrm{B}$ and adjacent vents in the north part of the caldera (Neal and others, 2003). Among all known historical eruptions, this eruption was most comparable to the 2008 eruption in style and size. The violent, phreatomagmatic nature of the 1817 eruption, coupled with credible reports of trace ash fall on Unalaska village, are consistent with that of the 2008 event. In addition to the 1817 event, several prominent post-caldera tuff cones and maar craters inside the caldera also attest to past phreatomagmatic eruptions at Okmok.

A similarly explosive mid-Holocene eruption from Okmok produced a thick series of scoria deposits along the south flanks (Middle Scoria sequence; Wong and Larsen, 2010). The Middle Scoria eruption produced up to $0.25 \mathrm{~km}^{3}$ DRE basaltic andesite magma, had a similar ash dispersal pattern (generally eastward from the caldera) to that of the 2008 and 1817 eruptions, and comparable calculated plume heights to the 2008 eruption (up to $14 \mathrm{~km} \mathrm{ASL}$ ). It also has an estimated VEI of 4.

\subsubsection{Eruptive volume comparison: 2008 versus 1997, 1958, and 1945 eruptions}

Prior studies used satellite imagery, field observations, and photogrammetry to estimate the lava flows' thicknesses, volumes, and growth of Cone A from three major eruptions in 1997, 1958, and 1945 (table 1). Patrick and others (2003) calculated a volume of 0.11 to $0.12 \mathrm{~km}^{3}$ DRE for the 1997 lava flow. Reeder (1984) estimated a bulk volume of 0.12 $\mathrm{km}^{3}$ for the 1958 lava flow; employing the Patrick and others (2003) vesicularity correction factor of 25 percent, the 1958 lava flow DRE volume is approximately $0.09 \mathrm{~km}^{3}$. The 1945 eruption produced a smaller lava flow, with an estimated bulk volume of $0.02 \mathrm{~km}^{3}$ (Byers and others, 1947), or $0.015 \mathrm{~km}^{3}$ DRE using a 25 percent correction factor. Grey
(2003) estimated a total Cone A bulk volume of $\sim 0.07 \mathrm{~km}^{3}$ following the 1945, 1958, and 1997 eruptions. Assuming 49 percent vesicularity is reasonable to correct Cone A scoria, the resulting DRE volume increase is approximately 0.03 $\mathrm{km}^{3}$. Although we have no estimates of tephra-fall volumes for any of the pre-2008 eruptions, those volumes are likely far less than that of the correlative lava flows.

In comparison with the three historical Cone A eruptions, the 2008 eruption produced minimum DRE volumes of 0.17 $\pm 0.06 \mathrm{~km}^{3}$ (table 1 ). This value exceeds the erupted magma volume for 1958 and 1997 eruptions by up to a factor of 3 for each. The 2008 eruption volume was approximately 1 order of magnitude greater than that produced in 1945.

The increase in eruptive volume associated with the 2008 eruption compared with the prior historical eruptions from Cone A likely reflects eruption of a larger volume of magma from subsurface magma reservoirs. The 2008 eruption is also unique because it erupted a slightly more evolved magma (55-57 wt. \% $\mathrm{SiO}_{2}$ compared with 52-53 wt. \% $\mathrm{SiO}_{2}$; Larsen and others, 2013). Further evidence from groundmass glass compositions $\left(\sim 51.5\right.$ to $56.5 \mathrm{wt}$. $\left.\% \mathrm{SiO}_{2}\right)$ indicates an influx of basaltic magma probably mingled with a more evolved magma to produce a hybrid basaltic andesite magma that then erupted (Larsen and others, 2013). The addition of a potentially older, more evolved magma tapped during the eruption from new vents to the north and west of Cone D could explain, at least in part, the increased eruptive volume over typical Cone A post-1900 eruptions.

Whether a sufficiently large amount of more evolved magma, entrained from beneath Cone $\mathrm{D}$ and mixed with fresh basaltic magma, could explain a roughly threefold increase in eruptive volume remains uncertain. An alternate explanation involves the mechanism of final magmatic ascent to the surface. Over the course of the 2008 eruption, vent migration, common in phreatomagmatic eruptions, produced an arcuate

Table 1. Summary of eruption type and maximum Volcano Explosivity Index (VEI) at Okmok volcano since the mid-Holocene.

\begin{tabular}{|c|c|c|c|c|}
\hline Year or Age & Eruption Type & $\begin{array}{c}\text { Maximum } \\
\text { VEI }\end{array}$ & $\begin{array}{l}\text { Volume } \\
\text { (DRE)* }\end{array}$ & References \\
\hline 2008 & $\begin{array}{l}\text { Multiple vents, } \\
\text { phreatomagmatic }\end{array}$ & 4 & 0.17 to $0.26 \mathrm{~km}^{3}$ & This report \\
\hline 1997 & $\begin{array}{l}\text { Cone A: effusive, } \\
\text { strombolian }\end{array}$ & $2-3^{a}$ & 0.11 to $0.12 \mathrm{~km}^{3 b}$ & $\begin{array}{l}{ }^{a} \text { Siebert and Simkin, 2002; } \\
{ }^{b} \text { Patrick and others, 2003; } \\
{ }^{b} \text { Lu and others, } 2003\end{array}$ \\
\hline 1958 & $\begin{array}{l}\text { Cone A: effusive, } \\
\text { strombolian }\end{array}$ & $2-3^{c}$ & $0.09 \mathrm{~km}^{3 d}$ & $\begin{array}{l}\text { c Siebert and Simkin, 2002; } \\
{ }^{d} \text { Reeder, } 1984\end{array}$ \\
\hline 1945 & $\begin{array}{l}\text { Cone A: effusive, } \\
\text { strombolian }\end{array}$ & $2-3^{e}$ & $0.015 \mathrm{~km}^{3 f}$ & $\begin{array}{l}{ }^{e} \text { Siebert and Simkin, 2002; } \\
{ }^{f} \text { Byers and others, } 1947\end{array}$ \\
\hline 1817 & $\begin{array}{l}\text { Phreatomagmatic and } \\
\text { effusive }\end{array}$ & $3-4^{g}$ & Undetermined & $\begin{array}{l}{ }^{g} \text { Simkin and Siebert (1994); } \\
\text { and this report }\end{array}$ \\
\hline $\begin{array}{l}\text { Mid- } \\
\text { Holocene }\end{array}$ & $\begin{array}{l}\text { Strombolian (Middle } \\
\text { Scoria sequence) }\end{array}$ & $4^{h}$ & Undetermined & ${ }^{h}$ Wong and Larsen, 2009 \\
\hline
\end{tabular}

*see text for explanation of vesicularity correction factors used to determine DRE (dense-rock-equivalent) volumes 
complex of maar craters and a single tephra cone over a region about $2 \mathrm{~km}$ in length. This geometry, as well as the geochemical character of the eruption products, indicates a dike likely fed the eruption, as opposed to a narrow vertical conduit (Larsen and others, 2013). The arcuate orientation is similar to that inferred for the 1817 eruption, and yet different from most recent historical Cone A eruptions, which originated from one location through time. The change in geometry of magma transport from a single, narrow, shallow, conduit feeding Cone $\mathrm{A}$, to the dike-fed eruption that occurred in 2008, allowing tapping of a larger proportion of magma within the magma reservoir, is a viable possibility. This reservoir is inferred to be approximately $2-5 \mathrm{~km}$ depth underneath the center of the caldera (Mann and others, 2002; Masterlark and others, 2010). Important remaining questions include: Why did such a change occur, and what is its significance to the future state of the Okmok magma system?

The 2008 eruption has helped refine our understanding of volcanic hazards and eruption styles expected from future events at Okmok. Although most historical eruptions have been effusive and centered on Cone A, several significant phreatomagmatic eruptions from Okmok since the midHolocene have occurred (Wong and Larsen, 2010), including several in the caldera in the past 2,000 years, forming maars, tuff cones, and associated features - two of those events (1817 and 2008) are historical. While twentieth-century effusive activity from Cone $\mathrm{A}$ is perhaps typical of what to expect from Okmok for an extended period (Begét and others, 2005), the 2008 eruption has demonstrated that future violent phreatomagmatic eruptions are also possible.

Surface and ground water play an important role in in eruption style and landform development at Okmok. Although the caldera floor slopes gently toward the Crater Creek/Gates region, draining most of the caldera toward the northeast, small lakes and streams are found in all sectors of the caldera. We expect phreatomagmatic eruptions from Okmok in the wetter regions of shallowest groundwater near cones B and D. However, older tuff cones and vents (such as Cone E) that have produced phreatomagmatic eruptions in the past are found in all parts of the caldera (fig. 3).

\subsection{Formation of collapse pits and escarpments}

As described in section 4.2.3, over the course of the 2008 eruption dozens of roughly circular pits formed in a $1 \times 3 \mathrm{~km}$ area northwest of Cone D. Pre-eruption, this was a relatively flat area filled by the 1958 ' a'a (fig. 3). Because the pits cut through and exposed sections of the 1958 lava flow beneath 2008 tephra, they were first interpreted as phreatic explosion craters formed in response to heated groundwater, similar to those at Mount St. Helens where on May 18, 1980, hot pyroclastic flows were deposited on wet ground (for example, Moyer and Swanson, 1987). However, the absence of raised rims or ejecta from the 1958 'a'a flow discounts an explosive origin. Instead, circumferential tension cracks and stair-stepped terraces in many pits, as well as a general alignment with pre-eruption subsurface drainage pathways, indicate formation by syneruptive collapse.

Underlying the 1958 ' a'a flow north of Cone D are saturated volcaniclastic sediments forming the pre-1958 swampy alluvial plain at the headwaters of Crater Creek described by Byers (1959). Photographs of the area after the 1958 lava flow show numerous water-vapor columns rising from the surface of the lava, attesting to abundant groundwater available for heating. The 2008 vents breached the surface along the margin of the 1958 lava flow and the Cone D lava bench, and formed several deep craters. About a week into the eruption, Cone D lake rapidly drained into the North vent. We are uncertain of the exact mechanism of near-vent sediment removal from beneath the 1958 lava flow, but we propose that groundwater and saturated sediment poured into the newly opened vents, creating void space large enough to accommodate the observed collapse features. Discrete zones of piping could occur if drawdown rates or volumes were uneven across the region, resulting in sinkholes or collapse pits (fig. 44).

Post eruption, the field of collapse pits began filling with remobilized 2008 tephra. Eventually, only the largest pits remained, and together they may punctuate a linear zone of the western caldera's former subsurface drainage system from what is now West Cone D lake to the headwaters of Crater Creek (fig. 26).

We propose a similar mechanism to explain the two prominent escarpments formed at the north and west margins of the vent region (described in section 4.3.4). As underlying sediment volume was lost due to rapid subsidence and lateral flowage toward adjacent vents, large sections of lava flow collapsed into newly formed craters. This occurred during ongoing tephra emission because, when visited in September 2008, portions of down-dropped lava blocks at the base of the master escarpments were thickly buried by 2008 tephra. Based on radar interpretation, the northern collapse formed between July 16 and 24, while the western escarpment formed later in the eruption, sometime between August 1 and the end of the eruption.

The collapse pits and arcuate escarpments formed at Okmok in 2008 are a surprising result of the interaction of explosive eruption and groundwater withdrawal in a caldera basin, and we are unaware of similar phenomena described elsewhere. Together, these collapse features at the margins of the vent complex further enlarged the region of apparent crater formation; this suggests caution while interpreting all crater-forms in phreatomagmatic terrain as primary vent features.

\subsection{Fumarolic activity associated with intracaldera cones}

Visual and thermal camera observations through time show a possible connection between some cones' fumarolic activity and temperature. Cone A has been the source of all eruptions since the late 1800 s to early 1900 s. Since its last 


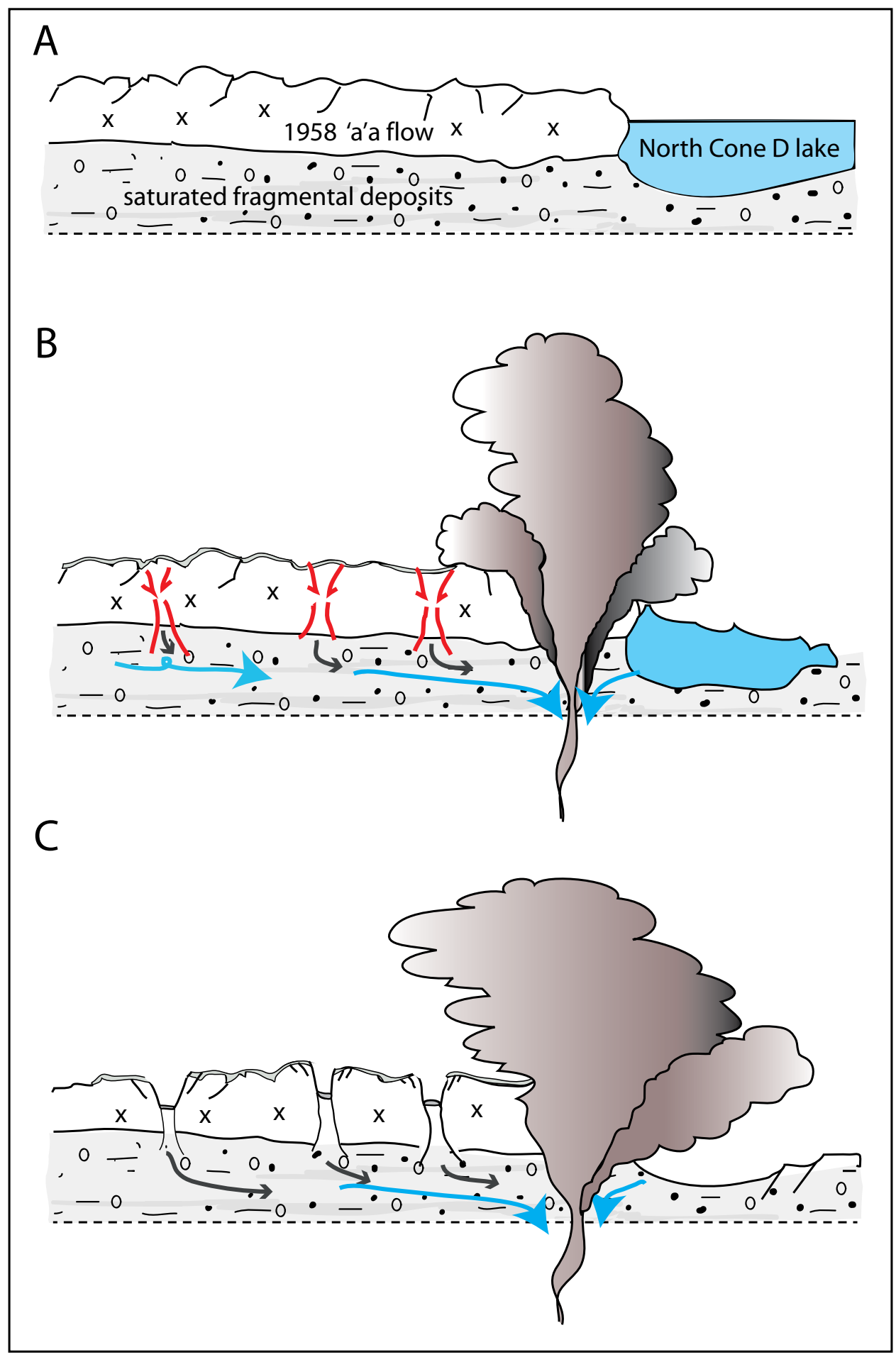

Figure 44. Cartoon illustrating our proposed mechanism for pit formation by stoping and collapse due to groundwater withdrawal. A. North Cone D lake formed when the 1958 'a'a lava flow impounded surface drainage in the region north of Cone D. The 1958 'a'a flow overran water-saturated volcaniclastic sediments to the north and west of Cone D (Byers and others, 1947). B. As the 2008 eruption began, vents were excavated through these sediments and the overlying 1958 lava flow. Solid material and groundwater poured into the vents, becoming a component of phreatic and phreatomagmatic explosions. This lateral movement and expulsion of material removed substrate beneath the 1958 lava flow and initiated points of subsidence and collapse. Ongoing tephra emission continued to mantle surfaces as they collapsed. C. As the eruption progressed, water and surficial materials continued to founder into the active crater. Subsidence continued, forming downdropped terraces and scalloped headwalls. 
eruption in 1997, active and vigorous fumaroles have been present in the northern of the two summit craters (fig. 29). As recently as 2004, venting of high-temperature gases produced incandescence. By the 2008 eruption, Cone A's northern crater had cooled considerably and hosted a small pond. During summer 2010, the northern Cone A crater was dry and possibly hotter, with fumarole activity still observed around its rim. We did not measure the temperatures in the crater during summer 2010, but the absence of the lake indicates a hotter, drier state had returned to Cone A. Conversely, during 2008, newly observed roiling in Cone E lake (where none had been observed from 2000 and 2004) indicates the opening of a fumarolic vent at that location. Possible causes include the shift in locus and/or severity of the 2008 eruption. It is uncertain whether recent observations of bare ground around the active fumaroles on Cone C's summit in the southern sector of the caldera indicate increased activity. Possibly, these visually observed changes in the 'thermal state' of some of the intracaldera cones indicate a connection between the pathways of past eruptions and a relatively high thermal gradient beneath the caldera (Mann and others, 2002). A shift in the eruption locus away from Cone A during 2008 probably signified a change in the thermal budget, resulting in a temporary cooling of magmatic pathways beneath Cone A. Further monitoring of fumarolic activity in the caldera may expand understanding of the active shallow magmatic plumbing at Okmok.

\section{CONCLUSIONS}

The five-week-long eruption of Okmok volcano JulyAugust 2008 created a new vent complex in the caldera, culminating with construction of a master $300-\mathrm{m}$-high tephra cone on the northwest flank of Cone D. The eruption was strongly phreatomagmatic, with abundant shallow groundwater and surface water feeding molten fuel-coolant interactions and generating voluminous fine-grained ash deposits.

Tens of meters of fine-grained deposits in the caldera and up to several meters high on the flanks of the volcano allowed lahars to sweep down all major drainages on the flanks of Okmok volcano. Pervasive rilling of the deposits on the mid to high flanks of the volcano indicates that rainfall and surface runoff was the primary cause of the lahars, with erosion and incorporation of underlying snow as a secondary factor. Lahars created large sediment deltas. Deltas formed at the mouths of all major stream channels along the south and north coastlines. These deltas grew to a maximum size (as observed through sporadic field work) by September 2008, and over the following two years largely eroded back toward the original shoreline, creating local thickening of beaches.

Lack of onsite observations and constant obscuration of the ground by ash and weather clouds meant that radar was the only tool useful to document first-order changes on the caldera floor as the eruption progressed. Radar data indicate that the initial ground disruption at the start of the eruption occurred over a broad region of the caldera floor, producing a complex set of craters and fractures that enlarged through time. Encroachment of one crater upon pre-existing North Cone D lake may have prompted rapid draining of the lake. Several craters were sites of continuing ash emission although only one, Ahmanilix, was active for the entire eruption.

A potentially unique outcome of the 2008 eruption is the role of collapse topography in response to groundwater and saturated sediment withdrawal. This is expressed in the series of collapse pits and arcuate escarpments that formed syneruptively in pre-existing lava flows north and west of the vent region. Taken as a group, these features extend roughly along a drainage pattern that now lies between the headwaters of Crater Creek and the new West Cone D lake. We suggest their formation is related to drainage of groundwater and saturated sediment into the new vents-a process that resulted in both sediment removal and sediment subsidence beneath the surficial lava flows. Coalescence of some of these craters through time produced large, roughly circular basins that could be mistaken for explosion crater topography. Thus, cratered terrain in phreatomagmatic eruption settings must be interpreted with care.

Tephra deposits along the primary northeast axis of deposition exhibit a coarse basal section comprising two separate layers of lapilli fall separated by a finer-grained ash-fall interval. Above the coarse base, the 2008 deposits shift sharply to repetitive layers of fine- to medium-grained olive-brown to grey ash.

More detailed investigations currently underway are designed to further describe and interpret the physical characteristics of the 2008 tephra deposits (Unema and others, written commun., 2014). Isopachs derived from the September 2008 field visit estimate a total eruption volume of $0.35 \pm$ $0.12 \mathrm{~km}^{3}$ (bulk) and 0.17 to $0.26 \mathrm{~km}^{3}$ DRE. In combination with maximum plume height estimates of $16 \mathrm{~km}$, we constrain a maximum VEI of 4 for the 2008 eruption.

\section{ACKNOWLEDGMENTS}

We dedicate this Report of Investigations to Lonnie Kennedy and the Kennedy family of the Bering Pacific Ranch at Fort Glenn, in appreciation for their generous assistance during our field campaigns, and keen observations of Okmok volcano before, during, and after the 2008 eruption. The authors thank the Kennedy family for permission to use Lonnie's photographs and observations. Rick Wessels and Russ Rykhus are gratefully acknowledged for assistance with FLIR and SAR image acquisition and processing. We also thank helicopter pilots Bill Springer and Kenny Clark for safely flying us around the volcano, often in less than ideal weather, in 2008 and 2010. Any use of trade, firm, or product names is for descriptive purposes only and does not imply endorsement by the State of Alaska or U.S. Government. 


\section{REFERENCES}

Almberg, L.D., 2003, Hydrovolcanism in Okmok Caldera, Alaska: Fairbanks, University of Alaska Fairbanks unpublished M.S. thesis, $57 \mathrm{p}$.

Bean, K.W., 1999, The Holocene eruptive history of Makushin Volcano, Alaska: Fairbanks, University of Alaska Fairbanks unpublished M.S. thesis, 130 p.

Begét, J.E., Larsen, J.F., Neal, C.A., Nye, C.J., and Schaefer, J.R., 2005, Preliminary volcano-hazard assessment for Okmok volcano, Umnak Island, Alaska: Alaska Division of Geological \& Geophysical Surveys Report of Investigation 2004-3, 32 p., 1 sheet, scale 1:150,000. doi:10.14509/7042

Bingham, D.K., and Stone, D.B., 1972, Palaeosecular variation of the geomagnetic field in the Aleutian Islands, Alaska: The Geophysical Journal of the Royal Astronomical Society, v. 28, no. 4, p. 317-335.

Burgisser, A., 2005, Physical volcanology of the 2,050 bp caldera-forming eruption of Okmok volcano, Alaska: Bulletin of Volcanology, v. 67, no. 6, p. 497-525.

Byers, F.M., Fisher, B., and Hopkins, D.M., 1947, Volcano investigations on Umnak Island: U.S. Geological Survey Alaskan Volcano Investigations Report 0002, p. 19-53.

Byers, F.M. Jr., 1959, Geology of Umnak and Bogoslof Islands, Aleutian Islands, Alaska, in Investigations of Alaskan volcanoes, U.S. Geological Survey Bulletin B 1028-L, p. 267-369, 5 sheets, scales 1:63,360, $1: 96,000$, and 1:300,000.

Fierstein, J.E., and Nathenson, Manuel, 1992, Another look at the calculation of fallout tephra volumes, Bulletin of Volcanology v. 54, no. 2, p. 156-167.

Finney, Benjamin, Turner, S.P., Hawkesworth, C.J., Larsen, J.F., Nye, C.J., George, Rhiannon, Bindeman, Ilya, and Eichelberger, J.E., 2008, Magmatic differentiation at an island-arc caldera-Okmok volcano, Aleutian Islands, Alaska: Journal of Petrology, v. 49, no. 5, p. 857-884.

Freymueller, J.T., and Kaufman, A.M., 2010, Changes in the magma system during the 2008 eruption of Okmok volcano, Alaska, based on GPS measurements: Journal of Geophysical Research, v. 115, no. B12, 14 p. doi:10.1029/2010JB007716

Gardner, C.A., and Guffanti, M.C., 2006, U.S. Geological Survey's Alert Notification System for Volcanic Activity: U.S. Geological Survey Fact Sheet 2006-3139, 4 p.

Grewingk, C., 1850, Grewingk's geology of Alaska and the northwest coast of America [edited by Marvin W. Falk, translation by Fritz Jaensch published 2003]: Fairbanks, Alaska, Rasmuson Library Historical Translation Series 11, The University of Alaska Press, $242 \mathrm{p}$.

Grey, D.M., 2003, Post-caldera eruptions at Okmok volcano, Umnak Island, Alaska, with emphasis on recent eruptions from Cone A: Fairbanks, University of Alaska Fairbanks unpublished M.S. thesis, $135 \mathrm{p}$.

Kay, S.M., and Kay, R.W., 1994, Aleutian magmas in space and time, in Plafker, George and Berg, H. C., eds., The
Geology of Alaska: Geological Society of America The Geology of North America series v. G-1, p. 687-722.

Kienle, J., Kyle, P.R., Self, Stephen, Motyka, R.J., and Lorenz, V., 1980, Ukinrek Maars, Alaska: I, April 1977 eruption sequence, petrology and tectonic setting: Journal of Volcanology and Geothermal Research, v. 7, no. 1, p. 11-37.

Larsen, J.F., Neal, C.A., Schaefer, J.R., Begét, J.E., and Nye, C.J., 2007, Late Pleistocene and Holocene calderaforming eruptions of Okmok Caldera, Aleutian Islands, Alaska: AGU Geophysical Monograph, Volcanism and Subduction; The Kamchatka Region, p. 343-364.

Larsen, J.F., Neal, C.A., Webley, Peter, Freymueller, J.T., Haney, M., McNutt, S., Schneider, D., Prejean, S., Schaefer, J.R.G., and Wessels, R., 2009, Eruption of Alaska volcano breaks historic pattern: Eos, Transactions, American Geophysical Union, v. 90, n. 20, p. 173-174.

Larsen, J.F., Śliwiński, M.G., Nye, C.J., Cameron, C., and Schaefer, J.R., 2013, The 2008 eruption of Okmok volcano, Alaska-Petrological and geochemical constraints on the subsurface magma plumbing system: Journal of Volcanology and Geothermal Research v. 264, p. 85-106.

Lu, Zhong, Mann, Dorte, Freymueller, J.T., and Meyer, D.J., 2000, Synthetic aperture radar interferometry of Okmok volcano, Alaska - Radar observations: Journal of Geophysical Research, v. 105, no. B5, p. 10,791-10,806. doi:10.1029/2000JB900034

Lu, Zhong, and Dzurisin, Daniel, 2010, Ground surface deformation patterns, magma supply, and magma storage at Okmok volcano, Alaska, inferred from InSAR analysis-2. Co-eruptive deflation, July-August 2008: Journal of Geophysical Research, v. 115, no. B, 13 p. doi:10.1029/2009JB006970

Lu, Zhong, and Dzurisin, Daniel, 2014, InSAR imaging of Aleutian volcanoes-Monitoring a volcanic arc from space: Springer Praxis Books, Geophysical Sciences, ISBN 978-3-642-00347-9, $388 \mathrm{p}$.

Lu, Zhong, Dzurisin, Daniel, Biggs, Juliet, Wicks, Charles, Jr., and McNutt, Steve, 2010, Ground surface deformation patterns, magma supply, and magma storage at Okmok volcano, Alaska from InSAR analysis-1. Inter-eruption deformation, 1997-2008: Journal of Geophysical Research, v. 115, no. B., 1 p. doi:10.1029/2009JB006969

Mann, Dorte, Freymueller, J.T., and Lu, Zhong, 2002, Deformation associated with the 1997 eruption of Okmok volcano, Alaska: Journal of Geophysical Research, v. 107, no. B4, p. 7-13.

Masterlark, Timothy, Haney, Matthew, Dickinson, Haylee, Fournier, Thomas, and Searcy, Cheryl, 2010, Rheologic and structural controls on the deformation of Okmok Volcano, Alaska: FEMs, InSAR, and ambient noise tomography: Journal of Geophysical Research v. 115, no. B2, 1 p. doi:10.1029/2009JB006324.

McGimsey, R.G., and Wallace, K.L., 1999, 1997 volcanic activity in Alaska and Kamchatka-Summary of events 
and response of the Alaska Volcano Observatory: U.S. Geological Survey Open-File Report 99-0448, 42 p.

Miller, D.M., Langmuir, C.H., Goldstein, S.L., and Franks, A.L., 1992, The importance of parental magma composition to calc-alkaline and tholeiitic evolution-Evidence from Umnak Island in the Aleutians: Journal of Geophysical Research, v. 97, no. B1, p. 321-343.

Miller, T.P., and Smith, R.L., 1987, Late Quaternary calderaforming eruptions in the eastern Aleutian arc, Alaska: Geology, v. 15, no. 5, p. 434-438.

Miller, T.P., McGimsey, R.G., Richter, D.H., Riehle, J.R., Nye, C.J., Yount, M.E., and Dumoulin, J.A., 1998, Cata$\log$ of the historically active volcanoes of Alaska: U.S. Geological Survey Open-File Report 98-0582, 104 p.

Moyer, T.C., and Swanson, D.A., 1987, Secondary hydroeruptions in pyroclastic-flow deposits-Examples from Mount St. Helens: Journal of Volcanology and Geothermal Research, v. 32, no. 4, p. 299-319.

Neal, C.A., Begét, J.E., Grey, D.M., and Wolfe, B.A., 2003, The 1817 eruption of Okmok Caldera, Umnak Island, Alaska-New insights into a complex historical eruption in the eastern Aleutians [abs.]: Eos Transactions of the American Geophysical Union, v. 84, no. 46, Fall Meeting Supplement, V42B-0342.

Neal, C.A., McGimsey, R.G., Dixon, J.P., Cameron, C.E., Nuzhaev, A.A., and Chibisova, M., 2011, 2008 Volcanic activity in Alaska, Kamchatka, and the Kurile IslandsSummary of events and response of the Alaska Volcano Observatory: U.S. Geological Survey Scientific Investigations Report 2010-5243, 94 p. http://pubs.usgs.gov/ $\underline{\text { sir/2010/5243 }}$

Newhall, C.G., and Self, Stephen, 1982, The volcanic explosivity index (VEI) - An estimate of explosive magnitude for historical volcanism: Journal of Geophysical Research, v. 87, no. C2, p. 1,231-1,238.

Nye, C.J., and Reid, M.R., 1986, Geochemistry of primary and least fractionated lavas from Okmok volcano, central Aleutians-Implications for arc magmagenesis: Journal of Geophysical Research, v. 91, no. B10, p. $10,271-10,287$.
Ort, M.H., Unema, J.A., Larsen, J.F., and Schaefer, J.R., 2012, Complex water-magma interaction during the 2008 eruption at Okmok volcano, Alaska [abs.]: Geological Society of America Abstracts with Programs, v. 44, no. 3, p. 12

Patrick, M.R., Dehn, Jonathan, Papp, K.R., Lu, Zhong, Dean, K., Moxey, L., Izbekov, P., and Guritz, R., 2003, The 1997 eruption of Okmok volcano, Alaska-A synthesis of remotely sensed imagery: Journal of Volcanology and Geothermal Research, v. 127, no. 1-2, p. 87-105.

Pyle, D.M., 1989, The thickness, volume and grain-size of tephra fall deposits: Bulletin of Volcanology, v. 51, no. 1, p. $1-15$.

Reeder, J.W., 1984, Okmok: Bulletin of Volcanic Eruptions, v. 22, p. 92-94.

Schaefer, J.R., Larsen, J.F., and Unema, J.A., 2012, Digital elevation model (DEM) and shaded relief image of Okmok Caldera, 2010: Alaska Division of Geological \& Geophysical Surveys Raw Data File 2011-6. doi:10.14509/23223

Schaefer, J.R., 2005, 30-meter shaded relief image of Okmok Volcano, Umnak Island, Alaska: Alaska Division of Geological \& Geophysical Surveys Raw Data File 2005-1. doi:10.14509/7041

Siebert, Lee, Simkin, Tom, and Kimberly, Paul, 2010, Volcanoes of the World [3nd ed.]: Berkeley, California, University of California Press, $551 \mathrm{p}$.

Wolfe, B.A., 2001, Paleohydrology of a catastrophic flood release from Okmok Caldera and post-flood eruption history at Okmok volcano, Umnak Island, Alaska: Fairbanks, University of Alaska Fairbanks unpublished M.S. thesis, $100 \mathrm{p}$.

Wolfe, B.A., and Begét, J.E., 2002, Destruction of an Aleut village by a catastrophic flood release from Okmok Caldera, Umnak Island, Alaska [abs.]: Abstracts with Programs - Geological Society of America, v. 34, no. 6.

Wong, L.J., and Larsen, J.F., 2010, The Middle Scoria sequence-A Holocene violent strombolian, subplinian, and phreatomagmatic eruption of Okmok volcano, Alaska: Bulletin of Volcanology, v. 72, no. 2, p. 17-31. 



\section{APPENDIX A}

Field station and sample location information. Locations are plotted in figure 6.

MPUA = Mass per unit area; OKTU is a seismic station on the south flank of Okmok; nd = no data.

\begin{tabular}{|c|c|c|c|c|c|}
\hline StationID & $\begin{array}{l}\text { North } \\
\text { Latitude } \\
\text { NAD83 }\end{array}$ & $\begin{array}{l}\text { West } \\
\text { Longitude } \\
\text { NAD83 }\end{array}$ & Date Visited & Description & $\begin{array}{l}\text { Outcrop } \\
\text { Thickness } \\
\text { (cm) }\end{array}$ \\
\hline 08JFLOK001 & 53.3854 & -167.9066 & 31-Jul-08 & $\begin{array}{l}\text { Tephra section. } 2008 \text { ash deposited on } \\
\text { asphalt "landing pad" at Fort Glenn ranch } \\
\text { house. }\end{array}$ & 3.2 \\
\hline 08JFLOK002 & 53.3914 & -167.9059 & 31-Jul-08 & $\begin{array}{l}\text { Pit into lahar deposits filling creek bed } \\
\text { just north of Ranch house. Logged } \\
\text { stratigraphy, sampled bulk deposits, } \\
\text { collected samples of large scoria clasts on } \\
\text { surface of the lahar deposits. }\end{array}$ & nd \\
\hline 08JFLOK003 & 53.3960 & -167.8388 & 31-Jul-08 & $\begin{array}{l}\text { Tephra section. Measured, logged, } \\
\text { sampled deposits preserved on a flat } \\
\text { board at the basalt "dock." }\end{array}$ & 1.91 \\
\hline 08JFLOK004 & 53.4671 & -167.3007 & 02-Aug-08 & $\begin{array}{l}\text { Grab sample on Unalaska Island of wet } \\
\text { ash clinging to lupines. }\end{array}$ & nd \\
\hline 08JFLOK005 & 53.4373 & -167.9480 & 08-Sep-08 & $\begin{array}{l}\text { Tephra section, ash sample at GPS site } \\
\text { NWFT. }\end{array}$ & 4.13 \\
\hline 08JFLOK006 & 53.2681 & -168.2220 & 09-Sep-08 & Tephra section and MPUA sample. & 0.20 \\
\hline 08JFLOK007 & 53.2895 & -168.1256 & 09-Sep-08 & Tephra section, bulk ash sample. & 0.95 \\
\hline 08JFLOK008 & 53.3260 & -167.9947 & 09-Sep-08 & $\begin{array}{l}\text { Lahar delta boulder measurements, } \\
\text { sketch. }\end{array}$ & nd \\
\hline 08JFLOK009 & 53.3276 & -167.9940 & 09-Sep-08 & $\begin{array}{l}\text { MPUA sample, } 10 \times 10 \mathrm{~cm} \text { from a flat rock } \\
\text { surface. }\end{array}$ & 3.81 \\
\hline 08JFLOK010 & 53.3256 & -167.9918 & 09-Sep-08 & $\begin{array}{l}\text { Bulk sample of lahar deposits (finer- } \\
\text { grained, late-stage) near beach berm. }\end{array}$ & nd \\
\hline 08JFLOK011 & 53.3423 & -168.0216 & 09-Sep-08 & $\begin{array}{l}\text { Bulk sample of lahar deposit from middle } \\
\text { of section atop pre-eruption grass. }\end{array}$ & 5.08 \\
\hline 08JFLOK012 & 53.3428 & -168.0212 & 09-Sep-08 & MPUA sample, $7.6 \times 7.6 \mathrm{~cm}$. & nd \\
\hline 08JFLOK013 & 53.5225 & -167.9036 & 09-Sep-08 & Tephra section. & 7.62 \\
\hline 08JFLOK014 & 53.3877 & -167.9064 & 09-Sep-08 & $\begin{array}{l}\text { Tephra section and MPUA sample, } 10 \times \\
10 \mathrm{~cm} \text {. }\end{array}$ & nd \\
\hline 08JFLOK015 & 53.4330 & -168.1140 & 09-Sep-08 & $\begin{array}{l}\text { Grab sample of bomb (lithic?) from rim of } \\
\text { new vent; location determined by } \\
\text { inspection of } 2010 \text { DEM. }\end{array}$ & nd \\
\hline 08JFLOK015A & 53.4512 & -168.1159 & 09-Sep-08 & $\begin{array}{l}\text { Tephra section. Minimum thickness } \\
\text { within the caldera. Could not reach base. } \\
\text { No sample collected. }\end{array}$ & nd \\
\hline 08JFLOK016 & 53.4646 & -168.0666 & 09-Sep-08 & Tephra section. Deposit rests on snow. & 232.00 \\
\hline 08JFLOK017 & 53.4808 & -168.0667 & 09-Sep-08 & Tephra section, no sample. & 60.00 \\
\hline 08JFLOK018 & 53.4828 & -168.0690 & 09-Sep-08 & Tephra section, no sample. & nd \\
\hline
\end{tabular}




\begin{tabular}{|c|c|c|c|c|c|}
\hline StationID & $\begin{array}{c}\text { North } \\
\text { Latitude } \\
\text { NAD83 } \\
\end{array}$ & $\begin{array}{c}\text { West } \\
\text { Longitude } \\
\text { NAD83 }\end{array}$ & Date Visited & Description & $\begin{array}{c}\text { Outcrop } \\
\text { Thickness } \\
\text { (cm) }\end{array}$ \\
\hline 08JFLOK019 & 53.4007 & -168.1208 & 11-Sep-08 & $\begin{array}{l}\text { Tephra section between Cones } \mathrm{C} \text { and } \mathrm{F} \\
\text { inside caldera. }\end{array}$ & 210.80 \\
\hline 08JFLOK020 & 53.3335 & -168.2747 & 11-Sep-08 & $\begin{array}{l}\text { Tephra section and MPUA sample, } 20 \times \\
20 \mathrm{~cm} \text {. }\end{array}$ & 7.62 \\
\hline 08JFLOK021 & 53.4530 & -168.1623 & 11-Sep-08 & Tephra section and sample. & 53.34 \\
\hline 08JFLOK022 & 53.4936 & -167.9974 & 11-Sep-08 & Tephra section and sample. & 27.94 \\
\hline 08JFLOK023 & 53.5603 & -167.9727 & 12-Sep-08 & $\begin{array}{l}\text { Tephra section and bulk lahar deposit } \\
\text { sample. }\end{array}$ & 0.30 \\
\hline 08JFLOK024 & 53.3163 & -168.1241 & 12-Sep-08 & $\begin{array}{l}\text { Tephra section and MPUA sample, } 20 \times \\
20 \mathrm{~cm} \text {. }\end{array}$ & 1.27 \\
\hline 08JFLOK025 & 53.3284 & -168.1007 & 12-Sep-08 & $\begin{array}{l}\text { Tephra section and MPUA sample, } 20 \times \\
20 \mathrm{~cm} \text {. }\end{array}$ & 3.81 \\
\hline 08JFLOK026 & 53.3648 & -167.9921 & 12-Sep-08 & Tephra section. & 7.62 \\
\hline 08JFLOK027 & 53.3475 & -167.9460 & 13-Sep-08 & Tephra section. & 4.45 \\
\hline 08JFLOK028 & 53.3451 & -167.9476 & 13-Sep-08 & $\begin{array}{l}\text { Tephra section and MPUA sample, } 15 \times \\
15 \mathrm{~cm} \text {. }\end{array}$ & 2.54 \\
\hline 08JFLOK029 & 53.3140 & -168.0269 & 13-Sep-08 & Tephra section. & 3.81 \\
\hline 08JFLOK030 & 53.4116 & -167.9092 & 13-Sep-08 & Tephra section, no sample. & 3.81 \\
\hline 08JFLOK031 & 53.4076 & -167.9619 & 13-Sep-08 & Tephra section, no sample. & 8.89 \\
\hline 08JFLOK032 & 53.4488 & -168.1200 & 14-Sep-08 & $\begin{array}{l}\text { Collapse crater. } 2008 \text { deposit thickness } \\
\text { approximately } 12.3 \mathrm{~m} \text { average }(+/-0.8 \mathrm{~m}) \text {. } \\
\text { Crater diameter } 110 \mathrm{~m} \text {. Estimated by } \\
\text { repeat measurements with laser } \\
\text { rangefinder. }\end{array}$ & $1,230.00$ \\
\hline 08JFLOK032A & 53.4482 & -168.1230 & 14-Sep-08 & $\begin{array}{l}\text { Estimate total collapse crater depth (laser } \\
\text { rangefinder): } 30.0(+/-0.4) \mathrm{m} \text {. }\end{array}$ & nd \\
\hline 08JFLOK033 & 53.4411 & -168.1381 & 14-Sep-08 & $\begin{array}{l}\text { Collapse crater. Depth estimated to be } \\
44.4 \mathrm{~m}(+/-5 \mathrm{~m}) \text {. This station also a GPS } \\
\text { spot elevation point, for correction for } \\
\text { lake elevation estimate. No sample. }\end{array}$ & 525.78 \\
\hline 08JFLOK034 & 53.4710 & -168.1214 & 14-Sep-08 & Tephra section, no sample. & 25.40 \\
\hline 08JFLOK035 & 53.4696 & -168.0886 & 14-Sep-08 & Tephra section, no sample. & 101.60 \\
\hline 08JFLOK036 & 53.4270 & -168.1636 & 14-Sep-08 & Tephra section, no sample. & 29.21 \\
\hline 08JFLOK037 & 53.4434 & -168.1423 & 14-Sep-08 & GPS measurement station. & nd \\
\hline 08JFLOK038 & 53.4473 & -168.0987 & 14-Sep-08 & $\begin{array}{l}\text { Very proximal tephra section. Only upper } \\
\text { layers measured directly. Laser } \\
\text { rangefinder estimate is } 5.1 \mathrm{~m} \text { total } \\
\text { thickness, atop the } 1958 \text { lava flow. }\end{array}$ & 510.00 \\
\hline 08JFLOK039 & 53.3839 & -168.0419 & 15-Sep-08 & Tephra section at OKTU, no sample. & 8.26 \\
\hline 08JFLOK040 & 53.4759 & -167.9446 & 15-Sep-08 & Tephra section, northeast flank of Idak. & 11.43 \\
\hline
\end{tabular}




\begin{tabular}{|c|c|c|c|c|c|}
\hline StationID & $\begin{array}{c}\text { North } \\
\text { Latitude } \\
\text { NAD83 } \\
\end{array}$ & $\begin{array}{c}\text { West } \\
\text { Longitude } \\
\text { NAD83 } \\
\end{array}$ & Date Visited & Description & $\begin{array}{c}\text { Outcrop } \\
\text { Thickness } \\
\text { (cm) }\end{array}$ \\
\hline 08JFLOK041 & 53.4602 & -168.0175 & 15-Sep-08 & Tephra section, upper northeast flank. & 49.0 \\
\hline 08JFLOK042 & 53.4191 & -168.1265 & 15-Sep-08 & $\begin{array}{l}\text { Minimum tephra thickness estimate, } \\
\text { Cone } \mathrm{C} \text { lake region. No sample. }\end{array}$ & $1,084.58$ \\
\hline 08JFLOK043 & 53.4598 & -168.1254 & 15-Sep-08 & Tephra section, Cone B. No sample. & 62.00 \\
\hline 08JRSOK001 & 53.8769 & -166.5373 & 31-Jul-08 & $\begin{array}{l}\text { Pumice from Front Beach in front of } \\
\text { church in Unalaska. }\end{array}$ & nd \\
\hline 08JRSOK002 & 53.8755 & -166.5350 & 31-Jul-08 & $\begin{array}{l}\text { Pumice from Front Beach at high tide } \\
\text { mark; } 0.3 \text { to } 2 \mathrm{~cm} \text { in size. }\end{array}$ & nd \\
\hline 08JRSOK003 & 53.8978 & -166.4631 & 31-Jul-08 & $\begin{array}{l}\text { Pumice from Summer's Bay beach, } \\
\text { Unalaska. Tan/brown, } 0.3 \text { to } 2.5 \mathrm{~cm} \text { in } \\
\text { size. Some portions of pumice black and } \\
\text { frothy. }\end{array}$ & nd \\
\hline 08JRSOK004 & 53.5000 & -166.8597 & 01-Aug-08 & $\begin{array}{l}\text { Ash sample from snowfield on Unalaska. } \\
\text { Reworked ash on snow makes snowfields } \\
\text { appear gray. }\end{array}$ & nd \\
\hline 08JRSOK005 & 53.7530 & -166.5835 & 01-Aug-08 & $\begin{array}{l}\text { Reworked ash sample from snowfield on } \\
\text { Unalaska. Collected with a lot of snow. }\end{array}$ & nd \\
\hline 08JRSOK006 & 53.7868 & -166.6869 & 02-Aug-08 & $\begin{array}{l}\text { Helicopter stop at } 800 \mathrm{ft} \text { on snowpatch } \\
\text { above Dutch Harbor. }\end{array}$ & nd \\
\hline CNOK08-1 & 53.3933 & -167.8449 & 12-Sep-08 & $\begin{array}{l}\text { Tephra section near Fort Glenn dock. } \\
\text { Basal } 1.4 \mathrm{~cm} \text { is a medium-coarse ash. }\end{array}$ & 1.7 \\
\hline CNOK08-2 & 53.3884 & -167.8576 & $12-$ Sep-08 & $\begin{array}{l}\text { Tephra section and MPUA sample, } 20 \times \\
20 \mathrm{~cm} \text { measured area from atop cement } \\
\text { foundation near turn-off to Hide Shed. }\end{array}$ & 1.5 \\
\hline CNOK08-3 & 53.3868 & -167.9080 & 13-Sep-08 & $\begin{array}{l}\text { Coarsest pumice clasts from pristine } \\
\text { surface inside box about } 1.5 \times 1.5 \mathrm{~m} \\
\text { square adjacent to Fort Glenn bunkhouse. } \\
\text { Up to } 3 \mathrm{~cm} \text { across, most } 1.5 \mathrm{~cm} \text { in longest } \\
\text { dimension. }\end{array}$ & nd \\
\hline CNOK08-4 & 53.4501 & -168.1200 & 14-Sep-08 & $\begin{array}{l}\text { Shoreline detritus (plant fragments, } \\
\text { rounded pumice) along shoreline of Cone } \\
\text { B lake. }\end{array}$ & nd \\
\hline CNOK08-5 & 53.4423 & -168.1456 & 14-Sep-08 & $\begin{array}{l}\text { Very frothy pumice up to } 10 \mathrm{~cm} \text { across } \\
\text { from shoreline of Cone } \mathrm{G} \text { lake. Dark } \\
\text { brown in color, glassy. Juvenile } 2008 \text { ? }\end{array}$ & nd \\
\hline CNOK08-6 & 53.4473 & -168.0987 & 14-Sep-08 & $\begin{array}{l}\text { Water sample taken at west shoreline } \\
\text { North Cone } \mathrm{D} \text { lake. Field } \mathrm{pH}=7.07 \text {, } \\
\text { temperature }=10.4^{\circ} \mathrm{C} \text {, conductivity }= \\
111.3 \mathrm{~ms} / \mathrm{m} .\end{array}$ & nd \\
\hline CNOK08-7 & 53.3868 & -167.9080 & 16-Sep-08 & $\begin{array}{l}\text { MPUA sample, } 20 \times 20 \mathrm{~cm} \text {, from trailer } \\
\text { bed at bunk house. }\end{array}$ & 3.0 \\
\hline
\end{tabular}

